\title{
The effect of different diets on faecal markers related to colorectal cancer risk: studies with vegetarians and urolithiasis patients
}

Citation for published version (APA):

van Faassen, A. (1996). The effect of different diets on faecal markers related to colorectal cancer risk: studies with vegetarians and urolithiasis patients. [Doctoral Thesis, Maastricht University]. Maastricht University Press. https://doi.org/10.26481/dis.19960510af

Document status and date:

Published: 01/01/1996

DOI:

10.26481/dis.19960510af

Document Version:

Publisher's PDF, also known as Version of record

Please check the document version of this publication:

- A submitted manuscript is the version of the article upon submission and before peer-review. There can be important differences between the submitted version and the official published version of record.

People interested in the research are advised to contact the author for the final version of the publication, or visit the DOI to the publisher's website.

- The final author version and the galley proof are versions of the publication after peer review.

- The final published version features the final layout of the paper including the volume, issue and page numbers.

Link to publication

\footnotetext{
General rights rights.

- You may freely distribute the URL identifying the publication in the public portal. please follow below link for the End User Agreement:

www.umlib.nl/taverne-license

Take down policy

If you believe that this document breaches copyright please contact us at:

repository@maastrichtuniversity.nl

providing details and we will investigate your claim.
}

Copyright and moral rights for the publications made accessible in the public portal are retained by the authors and/or other copyright owners and it is a condition of accessing publications that users recognise and abide by the legal requirements associated with these

- Users may download and print one copy of any publication from the public portal for the purpose of private study or research.

- You may not further distribute the material or use it for any profit-making activity or commercial gain

If the publication is distributed under the terms of Article $25 \mathrm{fa}$ of the Dutch Copyright Act, indicated by the "Taverne" license above, 


\section{The effect of different diets on faecal}

markers related to colorectal cancer risk Studies with vegetarians and urolithiasis patients 


\section{CIP-GEGEVENS KONINKLDJKE BIBLIOTHEEK DEN HAAG}

Faassen, Arendinat wan

The effect of different diets on faecal markers related to colorectal cancer risk : studics with vegetarians and urolithasis patients Arendima wan Faassen. -

Mastricht: Universitaire Pers Maastricht. - Ill.

Thesis Rijtesuniversiteir Limburg, Mastriche - With ref. ISBN 90-5278-213-X

Subject headings: diers / colorectal cancer/urolinhiasis.

Illustraties en omslang:

G. van Zonneveld, Audiovisuele Dienst, Academisch Ziekenhuis Maastriche

Producrie en druk:

Datawyse / Uniwersitaice Pers Maastricht 


\section{The effect of different diets on faecal markers related to colorectal cancer risk \\ Studies with vegetarians and urolithiasis patients}

\section{PROEFSCHRIFT}

ter verkrijging van de graad van doctor aan de Rijksuniversiteit Limburg te Maastricht, op gezag van de Rector Magnificus, Prof. Mr. M.J. Cohen, volgens het besluit van het College van Dekanen,

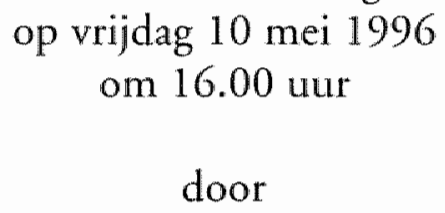

Arendina van Faassen 
Promotores:

Prof.dr. R.A. Janknegt

Prof.dr.ir. R.J.J. Hermus

\section{Copromotor:}

Dr. R. van der Meer (Rijksuniversiteit Groningen)

\section{Beoordelingscommissie:}

Prof.dr. P.B. Soeters (voorzitter)

Prof.dr. M.P. van Dieijen-Visser

Prof.dr. P.W. de Leeuw

Dr. F.M.N. Nagengast (Academisch Ziekenhuis Nijmegen Sint Radboud) Prof.dr. W.H.M. Saris

Het onderzoek was mogelijk door financiële ondersteuning van de Nederlandse Kankerbestrijding - Koningin Wilhelmina Fonds en de Stichting Zuivel, Voeding en Gezondheid. Beide organisaties droegen ook bij in de drukkosten van het proefschrift. 


\section{Contents}

Summary 7

Chapter 1

Introduction and objectives

Chapter 2

Determination of individual human faecal bile acids by gas-liquid chromatography after enzymatic deconjugation and simultaneous solvolysis and methylation using dimethoxypropane

\section{Chapter 3}

Bile acids, neutral steroids, and bacteria in faeces as affected by a mixed, a lacto-ovovegetarian, and an vegan diet

\section{Chapter 4}

Bile acids and $\mathrm{pH}$ values in total faeces and in faecal water from habitually omnivorous and vegetarian subjects

\section{Chapter 5}

Effects of a calcium binder on solubility of bile acids and fatty acids in the large intestine of the rat

\section{Chapter 6}

Effects of Calcisorb ${ }^{\circledR}$ on faecal bile acids and fatty acids in human wolunteers

\section{Chapter 7}

The calcium-restricted diet of urolithiasis patients with

hypercalciuria type Il: a benefit for kidney stones but a risk for colorectal cancer?

\section{Chapter 8}

General discussion and conclusions

Samenvatting 



\section{Summary}

Colorectal cancer is the second most common cancer among women and the third most common cancer among men in most Westernized countries. The treatment of colorectal cancer by surgery, farmaco- and radiotherapy has a 5 years survival of ca. $50 \%$. Therefore special atrention has been focussed on prevention. Colorectal cancer occurrence appears strongly influenced by environmental factors, among others diet. Some risk is inherited, but groups with dietary habits and lifestyle which are largely different from the general population like Seventh-day Adventists, Mormons and vegetarians, have lower mortalicy rates.

Studies on the pathogenesis of collorectal cancer show that it results from the accumulation of multiple mutacions in oncogenes and tumor suppressor genes. The latency between the first mutation and the occurrence of the disease is at least 20 years. Therefore biological markers of risk have been sought for in this long continuum of the pathogenetic chain. Because the colon and rectum are exposed both to blood and intestinal contents, markers of exposure may be found in both compartments. Remnants of the intestinal contents are found in faeces.

From literature before starting our studies (chapter 1) we hypothesized that a high dietary intake of meat, and a low intake of dietary fibre and calcium are related to a high risk of colorectal cancer. The concentrations of the secondary bile acids deoxycholic acid and lithocholic acid and of the long chain fatty acids in total faeces and in faecal water on one hand, but also faecal $\mathrm{pH}$ and faecal bulk are the faecal markers that are most probably related to colorectal cancer risk and that might be sensitive to dietary modulation.

The aim of this thesis was to study whether habitual dietary habits which are different in intake of meat, fibre and calcium (omnivorous, lacto-ovovegetarian, vegan and calcium-restricted dier of urolithiasis patients) will affect faecal markers for colorectal cancer risk. If the relations found are consistent with the data on diet and colorectal cancer risk, the biomarkers can be used as intermediate endpoints in epidemiological studies. If the data on biomarkers are explaining biologically the relation between diet and colorectal cancer risk, the hypotheses about diet and colorectal cancer are strenghtened. 
An accurate and valid analytical method for the determination of the concentration of faecal deoxycholic and lithocholic acid was developed (chapter 2). The method used in our next studies, which was based on this analytical method, gave figures for the main bile acids in human faeces that are similar to those acquired by methods from other laboratories. Moreover minor bile acids like the 3B-isomers of deoxycholic and lithocholic acid and the 7 - and 12 -kero bile acids could be quantitated (chapter 8). Deoxycholic acid, lithocholic acid and their $3 \alpha$-isomers are called secondary bile acids, because they are made by the intestinal bacteria from the primary bile acids chenodeoxycholic and cholic acid, which are formed in the liver.

In a strictly controlled study with male, young volunteers, the lacto-ovovegetarian and the vegan diet lowered the concentration of secondary bile acids in total faeces and enhanced faecal bulk and defaecation frequency compared to the mixed diet. The effects are most probably caused by the high amount of dietary fibre. The concentration of faecal secondary bile acids was higher on the lacro-ovo-vegetarian diet than on the vegan diet, most probably due to the higher amount of calcium in this diec "The vegan diec caused a lower faccal pH than the mixed and lacto-ovo-vegetarian diet (chapter 3).

The intake of dietary fibre is consistently negativelly associated with the risk of colorectal cancer in retrospective epidemiological studies. Also a faecal bullk higher than $200 \mathrm{~g} / \mathrm{d}$ was associated with a 3 times lower colorectal cancer risk in a correlation study. In a small study, patients with adenomatous polyps in the large bowel, which are considered as precursors of colorectal cancer, had higher concentrations of secondary bile acids in the faeces than healthy controls. Also, ulcerative colitis parients with high concentrations of secondary bile acids in faeces, had a higher risk on colorectal cancer than parients with low concentrations. Therefore the concentration of secondary bile acids in faeces may be used as an intermediate point in epidemiological studies. The role of faecal bulk, faecal $\mathrm{pH}$ and defaecation frequency have to be studied more intensively in prospective epidemiological studies before using them as a marker related to collorectal cancer. Moreover, the relation between intake of clietary fibre and colorectal cancer risk is strengthened by our results (chapter 8).

Habitual lacto-ovo-vegetarian men and women of $59-67$ yrs did not have lower concentrations of bile acids in cotal faeces but the concentration of secondary bile acids in the aqueous phase of the faeces was lower than in omnivores. The aqueous phase of faeces is obtained by high speed centrifugation and is supposed to be in contact with the colonic epitheliall cells. Faecal bulk and defaecation frequency were higher in the vegetarians than in omnivores and also higher in men than in women (chapter 4 ). Thirty percent of 
the variance in the concentration of deoxycholic acid in faecal water was explained by the intake of sarurated fat while $24 \%$ could be explained by the intake of cholesterol. Another twenty percent was explained by sex and faecal bulk. Also, wwenty percent of the variance in faecal bulk and defaecation frequency was explained by the intake of dietary fibre, especially from fruit and vegetables. Faecal $\mathrm{pH}$ did not differ between omnivores and vegetarians, but fourty-seven percent of the variance in faecal $\mathrm{pH}$ was explained by the calcium concentration in faeces and the faecal concentration of one of the main short chain fatty acids, butyrate.

The intake of saturated fat is not associated with an increased risk of colorectal cancer in all epidemiological studies. However a high consumption of food like red meat and eggs, are found to be associated with an increased risk. The relation between the concentration of secondary bile acids in faecal water and colorectal cancer risk has not yet been studied in large epidemiological studies (chapter 8).

Research by others showed that calcium-supplementation lowered the concentration of bile acids in faecal water. Moreover, epidemiological and experimental studies reported that a high intake of calcium may protect against colorectal carcinogenesis. The effects of a calcium-restriction on markers of colorectal cancer risk were not yet studied. We studied the effects in rats of a binder of calcium and magnesium (ethylene diamine tetra acetic acid, EDTA) (chapter 5). Moreover, in male volunteers the effects were studied of a medication that is used by a group of urolithiasis patients to prevent hyperabsorption of calcium: Calcisorb ${ }^{\circledR}$ (chapter 6). In both studies an increase was expected in the concentrations of bile acids and long chain fatty acids in the aqueous part of the colonic content and faeces respectively, however no significant changes could be detected. On the other hand, the concentrations of bile acids and long chain fatry acids in total faeces decreased. The results may be explained by the lowering of the bioavailability of calcium below 1000 $\mathrm{mg} / \mathrm{day}$; there are indications from literature that calcium-supplententation above $1000 \mathrm{mg} /$ day increases faecal bulk, which will decrease the concentration of deoxycholic acid in faecal water as can be derived from our study with the habitual omnivores and vegetarians. The concentrations of calcium and magnesium in faecal warer were lower after consuming these binders. The possible role of these concentrations in influencing colorectal cancer risk has to be studied further in animal and epidemiological sudies, because borh minerals also inhibit directly cell proliferation.

The adverse effects of the calcium-restricted diet of urolithiasis patients with hypercalciuria type II on faecal markers related to colorectal cancer risk, were studied in a randomized clinical trial. These patients have an increased 
absorption of calcium, which results in a high urinary excretion of calcium. The calcium-restricted diet might entiance the concentration of bile acids and long chain fatty acids in faecal water. However, this diet lowered the concentration of bile acids and long chain fatty acids in faecal water and its in vitro roxicity to red blood cells, most probably as a result of the lower intake of (saturated) fat and cholesterol that accompanies the calcium-restriction due to the omission of dairy products. The in vitro toxicity of faecal water was most strongly correlated with the concentration of long chain fatty acids in faecal water. Others have shown that the in vitro toxicity of faecal water to red blood cells correlates strongly with the in vitro toxicity to colonic epithelial cells and with hyperproliferation of epithelial cells of the large bowel in rats. Long chain fatry acids are suspected of increasing colorectal cancer risk because like bille acids, they actiwate protein kinase $C$. Protein kinase $\mathrm{C}$ is a key enzyme in cell proliferation. The relation between long chain farcy acids in faecal water and colorectall cancer risk has to be studied more deeply in epidemiological studies. Faecal pH did not change, but baseline values were positively associated with the concentration of calcium in faeces and negatively with the in vitro cytotoxicity of faecal water. Baseline values of faecal bulk correlated positively with the intake of calcium as measured by the urinary plus faecal excretion of calcium, especially above $1000 \mathrm{mg} /$ day. Moreover, sixty-five percent of the variation in the change in faecal bulk was explained by the change in calcium-intake measuresd as describe above.

In this study, also the effects of the calcium-restricted diet on risk factors for recurrent stone formation were checked. The urinary calcium-excretion decreased slightly and only in men; the urinary oxalate excretion decreased, although not significantly. The citrate excretion did not change (chapter 7).

The results of the clinical trial and recent literature prompted us to propose a new scheme for the diagnosis and dietary treatment of urolithiasis patients with calcium-oxalare stones, which has to be studied for efficiency and feasibility (chapter 8). Paricnts with a primary stone, should be screened by medical, clinical laboratary, dietary and antropometric methods. If there are no metabolic disturbances, a prudent diet as described by the Dutch guidelines for a healthy diet (moderate in meat, eggs, sugar and sodium, sufficient in calcium and fluid and rich in vegetables and fruits) should be advised. Recurrent patients should be studied on a calcium-rich, prudent diet and a calcium-low, prudent diet, in which the extra calcium is derived from tablets. Patients with decreasing urinary risk factors like the excretion of calcium, oxalare, urate, citrate and/or magnesium and whose urinary indicators of diet like uteum and sodium also decrease on the calcium-rich prudent diet, should follow the prudent diet clescribed above. Patients who show no decrease of urinary calcium excretion on the calcium-rich diet, but 
who respond to the calcium-low diet, are diagnosed as hypercalciuria type II and treated with a calcium- and oxalate-restricted and fluid enhanced diet. Further research is needed to select all patients that develop an increased risk for osteopenia on this diet.

Based on the results of our studies and on the literature, the model for the role of faecal constituents in the pathogenesis of colorectal cancer and for the influences of several dietary factors on the faecal constituents has to be adapted (chapter 8). Faecal constituents like long chain farty acids and hydrophobic bile acids in faecal water will increase the proliferation of colonic epithelial cells, which is associated with a higher expression of mutations. Is is concluded that there are strong indications that vegan diets will be provective for colorectal cancer due to their low saturated far and cholesterol content and their high amount of dietary fibre and resistant starch. Both will lead to low concentrations of hydrophobic bile acids and long chain fatty acids in faecal water. Moreower, the high amount of dietary fibre and resistant starch will enhance the production of butyrate in the colon, which will lower the hyperproliferarion of epithelial cells. Lacto-ovo-vegetarian diets which are not that low in saturated fat as vegan diets, may be protective because of their high amount of dietary fibre and their high calcium-content. Dietary fibre and a high intake of calcium will enhance faecal bulk and therefore lower the amount of hydrophobic bile acids and long chain fatty acids in faecal water. A thigh intake of calcium will also enhance faecal $\mathrm{pH}$, thereby resulting in a decrease of the amount of undissociated secondary bile acids. These undissociated acids are hydrophobic and therefore cytotoxic. Omnivorous diets which normally are low in dietary fibre, sometimes short in calcium and mostly rich in (saturated) fat and cholesterol from meat and eggs, may enhance the colorectal cancer risk.

The risk of recurrent urolithiasis in men which are genetically predisposed to calcium-oxalate stones, may be diminished slightly by a diet restricted in calcium. The risk of colorectal cancer may not be increased when the omitted milkproducts are not substiruted by products rich in animal protein like meat and eggs or by other food products. However in women, the same diet may be ineffective and may even increase their risk of osteoporosis. A prudent diet as described by the Durch guidelines for a healthy diet, should fulfill all requirements at the same time with regard to the risk of recurrent urinary calcium-oxalate stone forming, osteoporosis and colorectal cancer. 



\section{Chapter 1}

\section{Introduction and objectives}

\subsection{Diet, biological markers and colorectal cancer risk}

Cancer is the second cause of death in the Netherlands after heart and vascular diseases (1). Of each 100 subjects, 26 die of cancer. Colorectal cancer (CRC) is diagnosed each year in about 7000 Dutch men and women. It is the second most common cancer among women, behind breast cancer and the third most common one among men, after cancer of the lung and prostate (2). Also in other Western industrialised countries, the age-stratified incidence varied between 0.3 and $0.5 / 1000$ with the Netherlands on a third place after the USA and Canada. The treatment of CRC by surgery and radiotherapy has a five year survival rate of $50 \%$ (3). Therefore special atrention has been focused on prevention.

CRC occurrence appears to be strongly influenced by environmental factors, among orhers diet. The mortality rates generally increase among migrants from low to high-incidence areas and groups with dietary and lifestyle habirs different from the general popularion like Seventh-day Adventists, Mormons and vegetarians have lower mortality rates (4).

Some risk on CRC is inherited. Familial adenomatous polyposis and Gardner's syndrome are relatively uncommon syndromes in which extensive colonic polyp formation leads to the development op colon cancer. Some families have a high incidence of $\mathrm{CRC}$, wirhout extensive polyp formation. These groups are named hereditary non-polyposis CRC rypes.

Studies on the genetics of CRC resulted in a view that CRC results from the accumulation of multiple mutations in oncogenes and tumor suppressor genes (5). Some mutations are inherited, while others are the result of environmental factors. They may differ berween cancer of the colon and rectum and between subsites within the colon (6). However uncertainties in the classification at the border of colon and rectum prompted researchers often to combine them to CRC. 


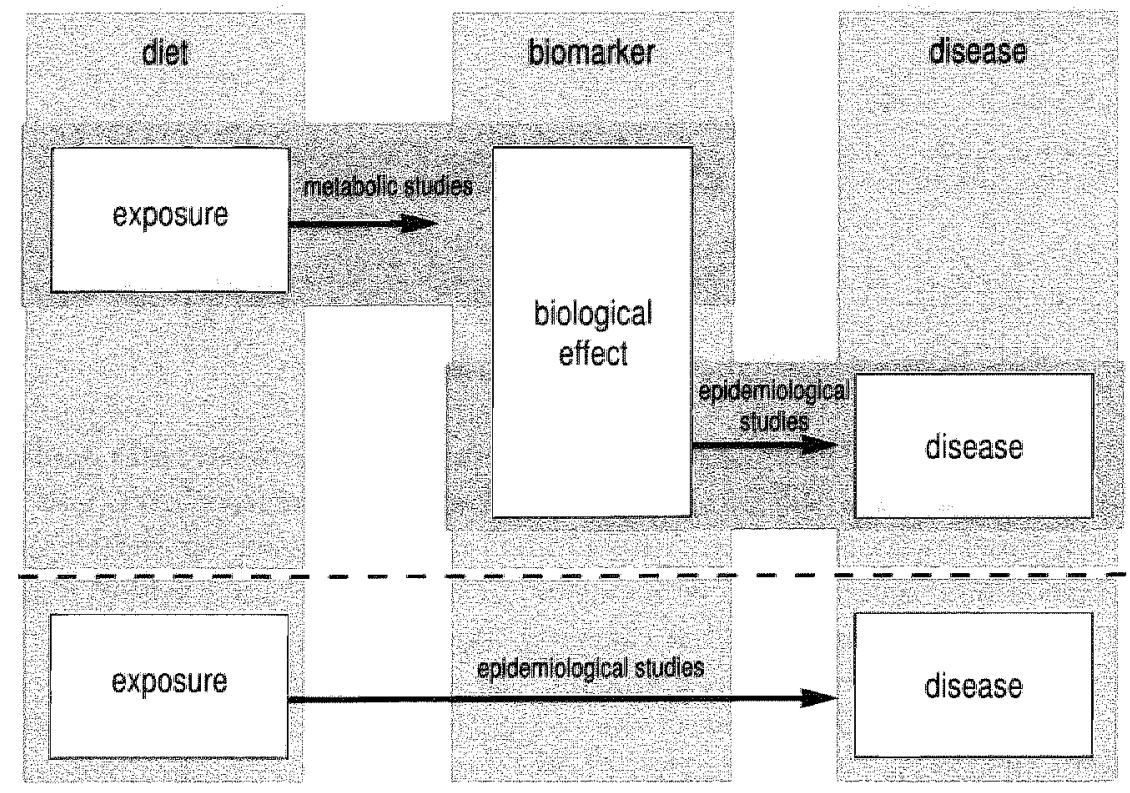

\section{FIGURE 1}

Combination of metabolic and epidemiological studies using biomarkers

The incidence of CRC is highest at ages above 75 yrs (3). The latency between the exposure that causes the first mutation and the occurrence of CRC is supposed to be ar least $20 \mathrm{yrs}$. Biological markers (biomarkers) of CRC risk in this long continum of the pathogenetic chain have been sought. These markers of risk are variables which values different from normal predict subsequent risk. They can be divided in three broad classes: markers of exposure, of effect and of susceptibility. At least 7 components are distinguished in the pathogenetic chain: markers of exposure, internal dose, effective dose, early biological effect, altered structure/function, clinical disease and of progression (7). In the research on diet and cancer biomarkers of exposurc have been used in metabolic and epidemiological investigations, for example studies on the effect of diet on faecall bulk and the relationship between this variable and CRC (see Figure 1). If the relations found are consistent with the data on diet and CRC risk, the biomarkers can be used as intermediate points in epidemiological studies. This kind of research has been called metabolic epidemiology (8). It is the variant of molecullar epidemiology (9), in which the biomarkers are metabolites reflecring the effecrive dose (7). Moreover, if the data on biomarkers are explaining biologically the relation between diet and CRC risk, the hypotheses about diet and CRC risk are strenghtened. 
CRC arises from the epithelial cells of the large intestine. The colon has one layer of cylindrical cells with a large amount of crypts, the recum several layers of squamous cells. These cells are exposed both to the intestinal contents and to blood. The colon is exposed to blood from the arteria mesenterica inferior, the rectum to the same and to blood from the arteria hypogastrica (10). Therefore markers of exposure may be found in blood or in the intestinal contents. An example of exposure by blood may be the concentration of folic acid in serum (11), which is a marker of the dietary intake and distribution of folic acid. A high intake of folic acid is associated with a low risk of CRC (12). A marker of exposure by the intestinal contents may be the concentration of bile acids (BA) in faeces, which is influenced by dier (13).

\subsection{Urolithiasis, diet and colorectal cancer risk}

Urinary stones are a common reason of patients to visit their physician. "The incidence in Germany (14) and the Netherlands (15) is about $0.5 \%$ per year. Of these stones $0.12 \%$ is a first stone (16), comparable to the incidence of diabetes in the Netherlands (17). At least $50 \%$ of the stone patients have a second event within 5 yrs when they are not treated against recurrence (18). The stones are formed in the renal calyces. At some time they are detached and start their drainage. When the stones reach the ureters, severe pain occurs. Moreover the stones can damage the tissues. Therapies are surgery, extracorporeal shock wave lithotripsy, or passing the stone with the urine. However the risk of recurrence can be lowered only by metaphylaxis. This should be based on risk factors or if possible on the etiological causes. There are several kinds of stones. About seventy five percent of the stones in adults of Western, industrialised countries are calcium $(\mathrm{Ca})$ oxalate stones, sometimes combined with phosphate $(19,20)$.

Risk factors for renal stone disease (urolithiasis) in general are genes, occupation, climate and diet. A small number of gene loci ( 3 a 4) are probably the principal contributors to the observed heritability of Ca-oxalate stone disease. Moreover adult men have atwofold higher risk for stones than women. The related genes may determine the levels of $\mathrm{Ca}$, oxalate and cirrate excreted in urine (21).

Professions with a sedentary style have a higher incidence of stones. Moreover when military subjects were placed in (sub)rropical areas the incidence of urolithiasis increased (22). 
Data from World War II show that when a country undergoes food and protein deprivation, the frequency of urinary stones decreases (23). Vegetarians in England have a 8 fold lower prevalence of stones than the general population of the same social class (24).

Urolithiasis patients with hypercalciuria type II are treated during the rest of their life with a Ca-restricted diet (25), because they have an increased absorption of $\mathrm{Ca}$. Patients with hypercalciuria type I do not respond strongly enough to a $\mathrm{Ca}$-restricted diet and therefore are treated with Calcisorb ${ }^{\text {i }}$, an oral binder of $\mathrm{Ca}$ composed of sodium cellulose phosphate (26). A low intake of $\mathrm{Ca}$ however, has been related to a high risk of CRC (27). Therefore urolithiasis patients with hypercalciuria type $I$ and II may ultimately experience a higher risk of CRC. Because the diagnosis of hypercalciuria type I and II is not made in most hospitals, classical epidemiological studies cannot be used to study the risk of these patients. The number of urolithiasis patients with hypercalciuria type I is too small for epidemiological studies, therefore the effect of their therapy on risk for CRC has to be studied in healthy volunteers.

\subsection{Review of the literature before 1990}

\subsubsection{Dietary factors and CRC risk}

A higher intake of meat, a lower intake of fibre and a lower intake of millkproducts were associated with a higher incidence of colon cancer in two Scandinavian countries (28). In a Canadian hospital based case-control study, the intake of saturated fat was positively associated with the incidence of CRC (29). In a hospital based case-control study in Greece, a higher intake of meat and a lower intake of vegetables appeared to have the highest risk of CRC (30). The intake of Ca was lower in CRC patients than in controls in the USA (27). Also a cohort study in the USA showed a prorective effect of $C a$ and vitamin D (31). In the USA, animal fat appeared to be a risk factor in a prospective study with women. (32). Total energy and protein intake was associated in a population based case-control study in Australia with an increased risk for colon and rectal cancer in both men and women consuming a low fibre dier (33).

\subsubsection{Dietary factors and faecal markers of CAC risk}

Cummings et al showed that the intake of dietary fibre from cereals and from fruir and vegetables increased daily faecal wet weight $(34,35)$. Also a high 
intake of starch increased faecal wet weight (36). Consumprion of fibre rich products increased defaecation frequency (37). Daily ingestion of large amounts of pectin-rich forms of dietary fibre such as 7 oranges (38), an experimental vegan diet (39) or 35 g commercial pectin (40) by young healthy males increased faecal $\mathrm{pH}$. Large amounts of other forms of dietary fibre such as com bran (41) or non-starch polysaccharides from wheat bran (42) did not lower faecal $\mathrm{pH}$. Thornton et al.(43) suggested that faecal $\mathrm{pH}$ also is influenced by the intake of polymeric carbohydrates. Consuming $150 \mathrm{~g}$ fat mainly of animal origin increased the faecal concentration of the main bile acids (BA) deoxycholic acid (DC) and lithocholic acid (LC) in total faeces (44). The ratio primary to secondary BA (cholic acid to DC and chenodeoxycholic acid to LC) increased after a diet rich in dietary fibre (45). The concentration of BA in faecal water increased after an intake of $90 \mathrm{~g}$ corn oil, while the concentration decreased after consuming $50 \mathrm{~g}$ less dierary fat (46). Allinger et al (47) described that the concentration of DC in faecal water decreased after shifting from a mixed to a lacrovegetarian diet. A dict with approximately $100 \mathrm{~g}$ saturated far increased the concentration of long chain fatty acids (LCFA) in total facces, while the concentration of BA did not increase (48). Newmark et al (49) hypothesised that Ca could bind the BA and LCFA in the intestine, thereby making them insoluble and thus less harmful for the colonic epithelium.

Also non-dietary factors influence the faecal biomarkers. Males have larger faecal bulk and higher defaecation frequencies than females $(41,42)$. Hormonal factors like those in pregnancy and the luteal phase of the ovalutory cycle decrease defaecation frequency (50). Bingham et al showed that physical acrivity does not seem to influence transit time or defaecation frequency in healthy subjects (51). Obese subjects have higher faecal concentrations of BA (52). Patients who had a cholecystectomy, have higher concentrations of faecal DC (53).

\subsubsection{Faecall markers and CRC risk}

Higher faecal wet weight was found in populations with a lower risk (28, 54-56). No data are available from case-control and prospective studies, most probably because of difficulties in getring reliable data.

Defaecation frequency did not differ significantly between popularion groups or between cases and controls $(56,57)$. Although the hypothesis of a shorter rime of contact between noxious agents in faeces and the colonic mucosa is biologically attractive, transit time and colorectal cancer incidence were not associated in a case-control study in Greece (58). With regard to the correla- 
tion studies, this may be due to the methods used to determine transit time, especially when they are long (59); in case-control studies the absence of an association may be a consequence of the disease rather than a cause. It may also result from non-representative case recruitment e.g. irregular defaecation of some colon cancer cases has been reported (60).

A high faecal $\mathrm{pH}$ has been associated with an increased risk of colorectal cancer in correlation studies between countries (55), within countries (61), as well as in a case-control study in the U.S.A. (62). Moreover, Samelson et al (63) reported that acidification of stools and shortened transit time due to dietary supplementation of rats with lactulose or sulphate diminished the number of colon tumours after treatment with dimethylhydrazine. On the other hand, rats treated with dimethylhydrazine and a low colonic $\mathrm{pH}$ due to consumption of high amounts of guar or pecrin showed a higher tumour incidence than controls (64). So, a short transit rime may have been the protective factor in the study of Samelson et al.

Brever and Goebell (65) showed in their review, that in epidemiological correlation studies and in some case-control studies an increased concentration of DC in total faeces was associated with a higher risk of CRC. Moreover, Hill et al (66) found in a prospective study with ulcerative colitis patients a high CRC risk for the concentration of DC in faeces. The ratio of primary to secondary bille acids was lower in high-risk patient groups (67). The ratio of $L C$ to DC was higher in patients than controls (68). In spontaneous colon cancer-bearing rats, a higher concentration of $\mathrm{DC}$ resulted in a higher incidence of tumours in the proximal colon (69). Application of DC and $\mathrm{LC}$ to the colonic mucosa or feeding diets that enhance the concentration of DC and LC in the colon, promoted chemically induced colorectal tumours in rats $(70,71)$.

More recently, Stadler et al (72) detected higher concentrations of DC in faecal water in patients than in controls. It has been postulated by Newmark et al (49) that this concentration might be a better marker for CRC risk than the concentration in total facces, because this concentration represents the amount of DC which is in contact with the colonic mucosa. Rafter et al (73) reported that a high concentration of DC combined with a high $\mathrm{pH}$ showed the most severely damaging effect on a perfused colon. DC, but not $\mathrm{LC}$ have been shown to be mutagenic (74), although the results could not be reproduced (75). Both were co-mutagenic $(76,77)$, co-carcinogenic $(78,79)$ and mitogenic (80). Increased cell proliferation would favour the occurrence and expression of generic damage. 
LCFA are shown also to be mitogenic (81). Populations at high risk for CRC had high concentrations of oleic acid, one of the main LCFA in faeces (82).

Short chain fatty acids (SCFA), the principal organic anions in the colon, have a trophic effect on the colonic epithelium (83). Colonic cells receive most of their nutrition from luminal SCFA, especially buryric acid (84). In addirion, buryric acid affects a number of cellular enzymes associated with cell differentiation and reduces the growth rate of human colorectal adenocarcinoma cell lines in vitro (85). Patients with adenomatous polyps or colon cancer had lower butyrate ratios in colonic contents than normal subjects (86). Adenomatous polyps in the colon are considered as precancerous lesions (87).

\subsubsection{Diel, deoxycholic acid and colorectal cancer risk.}

Studies on diet, faecal markers and CRC risk have been reported for humans and experimental animals, especially for DC. A higher meat, lower fibre and lower milk consumption coincided with a higher concentration of BA in faeces and a higher incidence of colon cancer in two Scandinavian countries (28). A high intake of fibre and a low concentration of BA in faeces occurred in the Scandinawian area with a low incidence of CRC (55). In a Japanese study, the concentration of DC in faeces was positively associated with the intake of fat and the incidence of colonic cancer (88). Nigro et al (89) showed that in rats a higher concentration of beef fat in the diet caused a higher concentration of DC in faeces and a higher incidence of colonic tumours.

From these data, we hypothesised that the intake of meat, dietary fibre and $\mathrm{Ca}$ may be related to the risk of CRC, that the concentration of DC in total faeces and in faecal water, the concentration of LCFA in total faeces and in faecal water, faecal $\mathrm{pH}$ and faecal bulk may constiute faecal markers that are related to CRC risk and sensitive to dietary modulation. We applied the first part of the approach shown in Figure 1 on the role of diet in the acriology of CRC by studying the effects of habitual diets differing in meat, fibre and $\mathrm{Ca}$ (omnivorous, vegetarian, vegan and Ca-restricted diets) on the faecal markers of biological effective dose related to CRC risk.

\section{Objectives}

The objectives of the investigations described in this thesis were:

1. to develop an accurate and valid analytical merhod for the determination of the concentrations of secondary faecal BA as markets of CRC risk 
2. to study the effects of an omnivorous, a lacto-vegetarian and a vegan diet in a controlled metabolic study with wolunteers on faecal bulk, $\mathrm{pH}$, defaccation frequency and $\mathrm{BA}$ in faeces as markers of CRC risk

3. to analyse the same faecal markers in habitual omnivores and vegetarians

4. to determine the effects of Calcisorb ${ }^{\circledR}$, which is given to urolithiasis patients with hypercalciuria type I, on the same faecal markers in a randomized, double-blind, placebo-controlled trial with volunteers preceded by a study with another $\mathrm{Ca}$-binder (erhylene diamine terra acetic acid, EDTA) in rats

5. to study the effects of the Ca-restricted diet of urolithiasis patienrs with hypercalciuria type II on the same faecal markers in a randomized clinical trial

The results of our studies with humans (metabolic, correlation and experimental) were compared with those from other reported studies and discussed from a pathogenetic point of view. Also the significance of the results for the CRC risk of omnivorous and vegetarian diets, the Calcisorb ${ }^{\circledR}$-treatment of urolithiasis patients with hypercalciuria type I and the Ca-restricted dier of urolithiasis patients with hypercalciuria type II were discussed. Some conclusions were drawn.

\section{References}

1. Central Bureau voor de Statistiek \& Ministerie van WVC Vademecum gezondheidstatistick Nederland, Den Haag, Staatsuitgeverij, 1994

2. Netherands Cancer Registry. Incidence of cancer in the Netherlands. Utrecht, LOK, 1991

3. Bueno de Mesquita, H.B. , Jansen, I., Taal, B. G. Dikke darm-en endeldarmkanker. In: Volksgezondheid Toekomst Verkenning. De gezondheidstoestand wan de Nederlandse bewolking in de periode 1950-2010. Ruwalard, D., Kramers, P.G.N. (red)., Den Haag, SDU Uitgeverii, 1993, p. 265-272

4. Kinsella, A.R. Colorectal caner: a scientific perspective. Cambridge, Cambridge University loress, 1993

5. Rusigi, A.K, Podolsky, D.K. The molecular basis of colon cancer. Annu. Rew Med. 43 (1992) $61-68$

6. Buftl, J.A. Colorectal cancer: evidence for distinct generic caregories based on proximal or distal cumor location. Anro. Intem.Med. 113 (1990)779-788

7. Hullia, B.S., Margolin, B. H. Methodological issues in epidemiologic studies using biological markers. \. Epidemiol. 135 (1992) 200-209

8. Wyader, E. L. Merabolic epdemiology. The Lancet i (1978) 260

9. Perera, F. P", Weinstein, 1.B. Molecular epidemiology and carcinogen-DNA adduct detecrion: New approaches ro studies of human cancer casation. J. Chronic Dis. 35 (1982) $581-600$

10. Jungueira, L.C., Canneiro, I., Kelley, R.O. Funcrionele histologic 5e druk, p. 414, Bunge, Urenche, 1990 
11. Jacques, P.F. Sulsky, S.l., Sadowski, J.A., Phillips, J.C.C., Rush, D. Willet, W.C. Comparison of micromutrient intake measured by dietary questionmaire and biochemial indicators of micronutrient status. Am.J.Clin. Mutr. 57 (1993) $1.82-189$

12. Frendenhem, J.L., Graham, S., Marshall, J.R., Haughey, B.P., Cholewinkk, S., Wilkinson, $G$. Folate intake and carcinogenesis of the colon and rectum. Int. I Epidemiol.20 (1990) $368-374$

13. Hill, M.J., Melville, D., Lennard Jones, J., Neale, K., Ritchie, J K. Faecal bile acids and dysplasia and carcinoma in ulcerative colitis. Lancet ii (1987) 185-186

14. Scharrel, O. Hesse, A. Die Bedeutung der Ernahrung in der Therapie des Harnsteinleidens. Teil 1: Kalziumoxalat-und Harnsauresteine. Ernahrungs-Umachau 41 (1994) $377-381$

15. Van de Lisdonk, E.H., van den Bosch, W. I.H.M., Huygen, F. I.A. Lagro-Jansen, A.L.M. Ziekten in de huisartspraktijk. Utrecht, Uirgeverij Bunge, 1990

16. Vahlensick, E.W., Bach, D., Hesse, A. Incidence, prevalence and mortality of urolithiasis in the German Federal Republic. Urol. Res. 10 (1982) 161-164

17. Ruward,D, Feskers, E.J.M. Diabetes mellitus. In: Volksgezondheid Toekomst Verkenning. De gezondheidstoestand van de Nederlandse bevolking in de periode 1950-2010. Ruward, D., Kramers, P.G.N. (red)., Den Haag, SDU Uitgeverii, 1993, p.303-307

18. Preminger,G.M. Renal calculi: pathogenesis, diagnosis, and medical therapy. Sem. Nephrol.12(1992) 200-216

19. Pak, C.Y.C. Eriology and treatment of urolithiasis. Am. J. Kidney Dis. 18 (1991) $624-637$

20. Scharrel, O, Hosse, A. Die Bedeutung der Emahrung in der Therapie des Harnsteinteidens. Teil 2: Phosphat-, Zystin- und seltene Steine. Emahrungs-Umschau 42 (1995) $127-131$

21. Goodman, H.O., Holmes, R.P., Assismos, D. G. Genetic factors in calcum oxalate stone disease. J. Urol. 153 (1995) $301-307$

22. Netelenbos, J.C. Bijschildklier-functie bij urinesteen-patienten. Hypothese-vormend onderzoek over idiopathisch urinesteenlijden. Proefschwif, Vije Universiteüt Amsterdam, Deventer, VE\&ES Dewenter b.v., 1977

23. Goldfarb, S. Dier and nephrolichiasis. Arnu.Rev.Med. 45 (1994) 235-243

24. Roberson, W.G., Peacock, M., Marhall, D.H. Prevalence of urinary stone disease in vegetarans. Eur. Urol. 8 (1982) 334-339

25. Pak, C.Y.C., Smith, L.H., Resnick, M.I., Weinerth, I.L. Dietary management of idiopatuic calcium urolithiasis. J. Unol. $131(1984) 850-852$

26. Churchill, D.N. Medical creament to prewent recurrent calcimm urolithisis. Mineral Electrolyte Metab 13 (1.987) 294-304

27. Slattery, M.L. Sorenson, A.W., Ford, M.H. Dietary calcium intake a a mitigating factor in colon cancer. Am. J. Epidemiol. 128 (1988) 504.514

28. IARC intestinal micro-ecology group. Dietary fibre, ransir-rime, faccal bacteria, steroids and colon cancer in wo scandinavian popularions. Lancet ii (1977) 207-211

29. Miller, A.B., Howe, G.R., Jain, M., Crails, K.J.P., Harrison, L. Food items and food groups as risk factors in a case-control study of diet and colorcetal cancer. Int. J. Cancer $32(1.983) 155-16)$

30. Manousos, O., Day, N.E., Trichopoulos, D. Gerowassilis, F., Tronou, A. Folychronopoulou, A. Diet and colorectal cancer: a case-control study in Greece. Int. I. Cancer $32(1983) 1-15$ 
31. Garland, C., Barret-Connor, E., Rousof, A.H., Shekelle, R. B., Crouui, M.H. and Paul, O. Dienary whamin $\mathrm{D}$ and calcium and risk of colorectal cancer: 1 19-year prospecrive sudy in men. Lancet i (1985) 307-309

32. Willer, W. The search for the canses of breast and colon cancer. Nanure 338 (1989) $389)-394$

33. Potter, 1.D. McMichael, A.]. Dien and cancer of the colon and rectum: a case-control study. J. Nad. Cancer Inst. 76 (1986) 557-569

34. Cummings, J.H. Southgate, D.A.T, Branch, W. Houston, H. Jenkins, D.J.A., James, W.P.T. The colonic response to dierary fibre form carror, cabbage, apple, bran and guar gum. Lancer i (1978) 5-9

35. Cummings, J.H., Hill, M.J. Jiwat, T. Houston, H., Branch, W. J., Jenkins, D.J.A. The eftect of meat protein and dietary fiber on colonic function and metabolism. I. Changes in bowel habit, bile acid excretion, and calcium absorption. Am. J. Clin. Nutr. 32 (1979) 2086.2093

36. Shetry, P.S., Kurpad, A.V. Increasing stanch incake in the human diet increases fecal butking. Am. J. Clin. Nutr. $43(1986) 210-212$

37. Stasse-Wolthuis M. Influence of dietry fibre on cholesterol metabolism and colonic function in healdhy subjects. Wrid. Rev. Nurr. Diet 36 (1981) 100-140

38. Wakcer, A.R.P., Walker, b. F., Segal, I. Faecal pH value and its modification by dietary means in South African black and white schoolchildren. S. Afr.Med.J. 55 (1979) 495698

39. wan Dokkum, W., de Bocr, B.C.J., wan Faassen, A., Pikar, N.A. Hermus, R.J.J. Diet, faccal pH and colorectal cancer. Br.J. Cancer 48 (1983) 109-110

40. Fleming, S.E., Marthinsen, D., Kuhalein, H. Colonic function and fermentation in men consuming high fiber diets. I. Nutr. 113 (1983) 2435-2544

41. Fleming, S.E., O'Donndl, A.U., Perman, J.A.. Influence of frequent and long-term bean consumption on colonic function and fermentation. Am. J. Clin. Nutr. 41 (1985) 909.918

42. Stephen, A.M., Wiggins, H.S., Englyst, H.N., Cole, T.J., Wayman, B.J., Cummings J.H. The effect of age, sex and level of intake of dietary fibre from wheat on large-bowel funcrion in thirty healthy subjects. Brit. J. Nutr. 56 (1986) 349-361

43. Thornton J.R., Dryden A., Kelleher J., Losowsky M.S. Super-efficient starch absoption. A risk factor for colonic neoplasia? Dig. Dis. Sci 32 (1987) 1088-1091

44. Cummings, J.H., Wiggins, H.S., Jenkins, D.J.A., Houston, H., Jivray, T., Drasar, B.5., Hil. M.I. Influence of diers trigh and low in animal far on bowel habit, gastrointestinal mansic time, fecil microhora, bile acid, and far excrevion. J. Clin.Inwest. 61 (1978) $953-963$

45. Ulrich. 1.H. Lai H.Y., Vona L., Reid, R.L., Abrink M.J. Alterations of fecal steroid. composition induced by changes in diecary fiber consumption. Am. I. Clin. Nurr. 34 (1981) $2054-2060$

46. Stadler J., Yeung, K.S. Furrer R., Marcon N. Himal H.S., Bruce W.R. Proliferative acrivity of rectal mucosa and soluble fecal bile acids in parients with normal colons and in patients with colonic polyps or cancer. Cancer Lerk. 38 (1988) 315-320

47. Allinger U.G., Johansson G.K... Rafter J.J. Shift from a mixed to actovegetaran dien: infucnce on acidic lipids in fecal water - a potential risk factor for colon cancer. Am. I. Clin. Nurr. $50(1989) 992.996$

48. Brussand,J.H., Katan, M.B., Haurvast, J.G.A.J. Fucal excretion of bile acids and neurral steroids on diets differing in type and amount of dietary far in young healahy persons. Eur,.Clin.lnvest. $13(1983) 115-122$ 
49. Newmark H.L. Wargovich M.J., Bruce W.R. Colon cancer and dietary fat phosphare, and calcium: a hypothesis. J. Natl. Cancer Inst. 72 (1984) 1323-1325

50. Davies, G.J., Crowder, M. Reid, B., Dickerson. J.W.T. Bowel function measurements of individuals with different eating patterns. Gur 27 (1986) 164-169

51. Bingham, S.A., Cummings, I.H. Effect of exercise and physical fitnes on large intestinal funcrion. Gastroenterology 97 (1989) 1389-1399

52. Mietinen, T.A. Clinical implicarions of bile acid metabolism in man. In: Bule acids. Nair P. ., Kritchevski D. (eds), Naw York, Plenum Press, 1976, vol.2, p. $191-247$

53. Brever, N.F, Jaekel, S., Dommes, P., Goebell, H. Fecal bile acid excretion parten in cholecystecromized patients. Dig. Dis Sci. 31(1986)95360

54. Reddy, B.S. Hedges, A.R., Laakso, K., Wynder, E.L. Metabolic epidemiology of large bowel cancer. Fectl bulk and constiments of high risk north american and low risk finnish population. Cancer $42(1978) 2832-2838$

55. Jensen, O.M., Madennan, R., Wahrendorf, J. Dier, bowel function, fecal chatacteristics, and large bowel cancer in Denmark and Finland. Nur. Cancer 4 (1982) 5-19)

56. Glober, G.A, Kamiyama, S., Nomura, A., Shimada, A., Abba, B.C. Bowel ransit-times and stool weight in populations with different colon-cancer risks. Lancer it (1977) $110-111$

57. Nakamura, G.J., Lawrence, J., Schneidernan, J., Klauber, M.R. Colorectal cancer and bowel habics. Cancer 54 (1984) 1475-1477

58. Papadimitriou, C. Day, M., Tzonou, A., Gerovassilis, F., Manousos, O. Trichopoulos, D. Biosucial correlates of colorectal cancer in Greece. Int. J. Epidemiol. 13 (1984) 155-159

59. Cummings, J.H., Jenkins, D. I.A., Wiggins, H.S. Measurement of the mean transir time of dietary residue through the human gut. Gut 17 (1976) 210-218

60. Moskovitz, M., White, C., Barnete, R.N., Stevens, S., Ruscell, E., Vargo, D., Hoch, M.H. Diet, fecal bile acids, and neutral sterols in carcinoma of the colon. Dig. Dis. Sci. 24 (1979) 746-751

61. Erich, M.. Aswell, J.E., Tassefl, R.L. van, Wilkins, T.D., Walker, A.R.P., Richardson, N.I. Mutagens in the feces of 3 South-African populations at different levels of risk for colon cancer. Mutation Res. 64 (1979) 231-240

62. Macdonald, I.A., Webb, G.R., Mahony, D. Fecal bydroxysteroid dehydrogenase activities in vegetarian Seventh-Day Adventists, control subjects, and bowel cancer parients. Am. J. Clin. Nutr. 31 (1978) \$233-\$238

63. Samelson, S.L., Nelson, R.L., Nythus, L.M. Protecrive role of faceal pH in experimencal carcinogenesis. J. Royal Soc. Med. 78 (1985) 230-233

64. Jacobs, L..R., Lupton, J.R. Relationship between colonic luininal pH, cell proliferation. and colon carcinogenesis in 1,2-dimethylhydrane-reated rars fed high fiber diets. Cancer Res. 46 (1986) 1727-1734

65. Breuer, N. Goebell, H. The role of bile acids in colonic carcinogenesis. Klin. Wochenschr. $63(1985) 97-105$

66. Hill, M.]. Melville, D., Lemard-Jones, J. Neale, K., Ritchie, J.K. Faccal bile acids and dysplasia and carcinoma in ulcerative colitis. Lancet ii (1987) 185-186

67. Mckeigue, P.M., Adelstein, A.M. Marmot ,M.G., Henly, P.J., Owen, R.W., Hill.M.J., Thompson, M.H. Diet and fecal steroid profile in a Soum Asian population with a low colon-cancer race. Am. J. Clin. Nutr. $50(1989) 151-154$

68. Owen, R.W., Dodo, M., Thompson, M.H., Hill, M. . The faecal ratio of lithocholic acid no deoxycholic acid may be an improtant actiological factor in colo-rectal cancer. Biochem. Soc Trans. $12(1984) 86$ 
69. Hayahi, E., Amuro, Y., Endo, T., Yamamoto, H. Miyamoro, M. Kishimoto, S. Fecal bile acids and neutral sterols in tats with spontaneous colon cancer. In. I. Cancer 37 (1986) $629-632$

70. Narisawa, T., Magadia, N.E., Weisburger, J.H., Wynder, E.L. Promozing effect of bile acids on colon carcinogenesis after intrarectal insillation of MNNG in rats. I. Natd. Cancer Inst. $55(1974) \quad 1093-1097$

71. Nigro, N.D., Singh, D.V., Campbell, R.L., Cook, M.Effece of dierary beef far on incestind rumour fonmation by axoxymethane in racs. J. Natl. Cancer Inst. 54 (1975) $439-442$

72. Stadler, I, Yeung, K.S., Furrer, R., Marcon, N., Himal, H.S., Bruce, W.R. Proliferative activicy of recal mucosa and soluble fecal bile acids in patients with nomal colons and in paticnts with colonic polyps or cancer. Cancer Lett. 38 (1988) 315-320

73. Rafter. J. . Eng, V.W.S., Furrer, R. Medine, A., Bruce, WR. Effects of calcium and pH on whe mucosal damage produced by deoxycholic acid in the rat colon. Gut 27(1986) $1320-1329$

74. Wacabe, J., Bernstein, H. The mutagenicity of bile acids using a fluctuation test. Mutation Res. $158(1985) 45-51$

75. Ventre, S., Bosworth, D., Easton, D.F. Lack of mutagenicity of bile acids in bacterial Alucuation tess. Mutation Res. 190(1987) 191-196

76. Wilpart, M. Mainguet, P. Maskens, A., Roberfroid, M. Mutagenicity of 1,2-dimethylhydrazine toward salmonella tryphimurium, co-mugenic effect of secondary biliary acids. Carcinogenesis 4 (1983) $45-48$

77. Silverman, S.J., Andrews, A. W. Bile acids: comutagenic activity in the Salmonella-mammalian micromsome muragenicity test. ). Natl. Cancer Inst. 59 (1977) 1557-1559

78. Cohen, B.I., Raiche, F.F., Deschner, E.E., Takahiashi, M., Sarwal, A.M., Fazzini, E. Effect of cholic acid feeding on $\mathrm{N}$-methyl-N-nicrosurea induced colon tumors and celle kinetics in ras. J. Nad. Cancen Inst. 64 (1980) $573-578$

79. Martin, M.S., Justrabo, E., Jeannin, J.F., Leclere, A., Marin, F. Effect of diecary chenodeoxycholic acid on intestinal carcinogenesis induced by 1,2-dimethylhydrazine in mice and hamsters. Br. J. Cancer 43 (1981) $884-886$

80. Deschner, E.E., Raiche R.F. Influence of bile on kinetic behaviours of colonic epithelial cells of the rat. Digestion 19 (1979) $322-327$

81. Wargovich, M.J. Eng, V.W.S., Newmark, H.L. Calcium inhibits the damaging and compensatory proliferative effects of farty acids on mouse colon epithelium. Cancer Let. 23 (1984) 253-258

82. Sperty. IF., Salyers, A.A., Wilkins, T.D., Fecal long chain farty acids and colon cancer risk. Lipids 11 (1976) $637-639$

83. Fouric, B., Forrent, C. Jouany, J.P. Colonic metabolism of whear starch in healdhy humans. Efrecis of fecal outputs and clinical symptoms. Gastroenterology 90 (1986) 111.119

84. Rocdiger, W.E.W. Role of anaerobic bacreria in the meabolic welfate of the colonic mucosa in men, Gut $21(1980) 793-798$

85. Whitehead, R.H., Young, G.P., Bhatal, P.S. Efects of short chain farty acids on a new human colon carcinoma cell line (LM1215). Gut 27 (1986) $1457-1463$

86. Weaver, G.A., Krausc, J.A. Miller,T.L., Wolin. M.J., Shor chain fary acid distributions of enema samples from a sigmoidoscopy population an associarion of thigh acerate and low buryrate ratios with adenomatous polyps and colon cancer. Gut 29 (1988) 1539 1543 
87. Day, D.W., Morson, B.C. The adenoma-Carcinoma sequence. In: Morson, B.C. (ed) The pathogenesis of colorectal cancer. Philadelphia, U.S.A., W.B. Sanders, 1978, p 58-71

88. Mower, H.F., Ray, R.M., Shoff, R., Sremmeman, G.N. Nomara, A., Glober, G.A., Kamigama, S., Shimada, A. Yamakawa, H. Fecal bile acids in two lapanese popularions with differen colon cancer risks. Cancer Res. 39 (1979) 328-331

89. Nigro, N.D., Campbell, R.L., Singh, S.V., Lin, Y.N. Wffect of dier high in beef far on the composition of fecal bile acids during intestinal carcinogenesis in the rat. ). Natl. Cancer Inse 47 (1976) 883-888 

Determination of individual human faecal bile acids by gas-liquid chromatography after enzymatic deconjugation and simultaneous solvolysis and methylation using dimethoxypropane

Arendina van Faassen, Fokko M. Nagengast, Magda Hectors, Wim J.M. van den Broek, Anton W.M. Huijbregts, Sjoerd D.J. van der Werf, Gerard P. vam Berge Henegouwen and Jan H.M. van Tongeren

Based on: Clin. Chim. Acta 152 (1985) 231-239

Introduction

In recent years there has been a renewed interest in the measurement of faecal bile acids, because of their possible involvement in colorectal carcinogenesis $(1,2)$.

Several methods have been employed for the determination of individual bile acids in human faeces (3-8). Major problems in the measurement are the extraction of bile acids from the particulate matter in the stool and interference of fatty acids and neutral steroids in the gas-liquid chromatographic (GLC) analysis. Furthermore, conjugated and/or sulfated bile acids can be present in human faeces; therefore, a deconjugation and solvolysis step should be included in the analytical procedure (9-15).

Recently, a very deailed method has been described in which all faecal bile acid metabolites are measured, including conjugated and sulfated (16). The procedure, however, is time-consuming and needs expensive and not widely available equipment like capillary GLC-mass spectrometry. 
We developed a rapid GLC procedure for the determination of individual human faecal bile acids, using enzymatic deconjugation and subsequenty solvolysis and methylation in one step with 2,2-dimethoxypropane.

\section{Materiais and methods}

\section{Chemicals}

All reagents for extraction and analysis were of analytical grade and obtained from Merck Darmstadt (FRG). B-Cholylglycine hydrolase (EC 35.12.24; spec. acr. $7194 \mathrm{U} / \mathrm{mg}$ protein; $1.39 \mathrm{mg}$ protein/ml) was obtained from Schwarz-Mann (Orangeburg, NY, USA).

\section{Bile acid standards}

The following reference bile acids were obrained from Steraloids Inc. (Wilton, NH, USA): lithocholic acid (LC), deoxycholic acid (DC), chenodeoxycholic acid (CDC), cholic acid (C) and 7-kerodeoxycholic acid (7-K-DC). Taurocholic acid (TC) and glycocholic acid (GC) were obtained from Calbiochemical (San Diego, CA, USA). The sulfated bile acids 3, $\alpha$-sul-folithocholic acid (SLC), 30-sulfodeoxycholic acid (SDC) and sulfochenodeoxycholic acid (SCDC; consisting of 70\% $3 \alpha$-sulfo CDC and $30 \%$ $7 \alpha$-sulfo CDC) were obtained from P.L.-Biochemicals (Milwaukee, WI, USA). All reference bile acids were $>95 \%$ pure.

Radiolabelled $\left[24{ }^{14}\right.$ Cllithocholic acid $(50 \mathrm{mCi} / \mathrm{mmol})$ and [24$\llbracket 4 \mathrm{C}$ ) deoxycholic acid ( $60 \mathrm{mCi} / \mathrm{mmol}$ ) were obtained from the Radiochemical Centre (Amersham, UK). $\left[24-{ }^{14} \mathrm{C}\right]$ Chenodeoxycholic acid $(50 \mathrm{mCi} / \mathrm{mmol})$ was obtained from New England Nuclear (Boston, MA, USA).

\section{Instruments}

Faeces were homogenized using a Philips mixer and freeze-dried subsequently in a Breda Scientific Freeze dryer LY-S-FM. Gas-liquid chromatography was performed on a F \& M 402 high efficiency chromatograph (Hewlett Packard, Avondale, USA) with a U-shaped all glass column, $1.20 \mathrm{~m} \mathrm{X} 3 \mathrm{~mm} \mathrm{i.d.,}$ packed with 1\% OV-210 on Gaschrom Q, 100-120 mesh (Chrompack, Middelburg, The Netherlands). Operating conditions for GLC were: oven remperature $235^{\circ} \mathrm{C}$, temperature injection point $250^{\circ} \mathrm{C}$, temperature flame ionisation detector $245^{\circ} \mathrm{C}$. Nitrogen was used as a carrier gas, flow rate 20 
$\mathrm{ml} / \mathrm{min}$; hydrogen $40 \mathrm{ml} / \mathrm{min}$, air $310 \mathrm{ml} / \mathrm{min}$. Retention times and peak areas were measured with a computing integrator (Minigrator, SpectraPhysics, Eindhoven, The Netherlands) and chromatograms recorded on a recorder of Honeywell Controls LTD (UK). Radioactivity was determined in a Philips liquid scincillarion counter PW 4700 (Philips, The Netherlands). Combustion of faccal samples for determination of total ${ }^{14} \mathrm{C}$-radioactivity was performed in a sample oxidator (17).

\section{Collection and preparation of faeces}

Fresh woided faeces were collected and frozen in solid $\mathrm{CO}_{2}$. After weighing, this was diluted with a known amount of distilled water and homogenized with a mixer at a temperature of $80^{\circ} \mathrm{C}$ (to speed up thawing and denaturate bile acid converting enzymes). A sample $(10 \mathrm{~g})$ was immediately frozen $\left(-20^{\circ} \mathrm{C}\right)$, lyophilized for $48 \mathrm{~h}$ and stored at $-20^{\circ} \mathrm{C}$ until analysis.

\section{Analytical procedure}

The method is a modification of the Grundy technique (3). The procedure is illustrated in the flow sheet (Fig. 1). The procedure is described here stepwise.

Enzymatic deconjugation $50 \mathrm{mg}$ lyophilized faeces are weighed in a glass stoppered centrifuge rube. Two millilitres of $0.1 \mathrm{~mol} / 1$ sodium acetate buffer (pH 5.7 with $2.0 \mathrm{~g}$ EDTA/l and $0.2 \mathrm{~m} \| \mathbb{B}$-mercaptoethanol/l) and $50 \mu \mathrm{l}$ cholylglycine hydrolase are added. Incubation is carried out overnight in a warerbath at $37^{\circ} \mathrm{C}$.

Saponification To each sample $0.1 \mathrm{ml} 5 \mathrm{mmol} / \mathrm{l}$ 7-K-DC are added as an internal standard to correct for losses during the procedure. One millilitre of $10 \mathrm{~mol} / 1$ sodium hydroxide, $6 \mathrm{ml}$ methanol and some boiling chips are added and the mixture is refluxed for $2 \mathrm{~h}$ at boiling point.

Extraction of neutral steroids Neutral steroids are extracted 3 times in petroleum ether after shaking and centrifugation.

Solvolysis and methylation After the extraction of the neutral steroids $1.0 \mathrm{ml}$ $\mathrm{HCl}$ and $7.0 \mathrm{ml} \mathrm{DMP} / \mathrm{ml}$ aqueous solution is added. After mixing, incubation is carried out for $18 \mathrm{~h}$ in the dark (to prevent formation of pigment polymers) at $37^{\circ} \mathrm{C}$. After this overnight incubation the mixture is evaporated under a stream of nitrogen at $50^{\circ} \mathrm{C}$. Beyond this temperature, a dark brown residue will appear due to the formation of pigment polymers. 


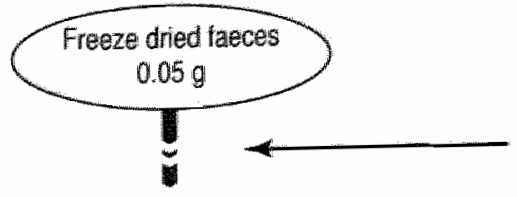

add $2 \mathrm{ml}$ sodiumacetate butter pH 5.7

incubation overnight with

cholylglycinehydrolase at $37^{\circ} \mathrm{C}$

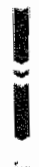

add $7 \mathrm{KDC} 0.1 \mathrm{~m}$

5 mmol/ (int.stand)

reflux for 2 hour in 1 mol/ $\mathrm{NaOH}$ in

$68 \%$ methanol at boiling point $\left(80^{\circ} \mathrm{C}\right)$

extract of neutral

steroinds in

petroleum ether

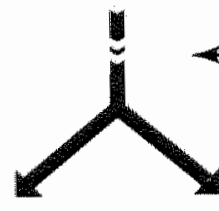

alkaline solution of

ble acids

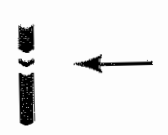

add $1 \mathrm{ml} \mathrm{HCL}$

add $7 \mathrm{ml} \mathrm{DMP}$ per ml

aqueous solution

extract 3 times with

$10 \mathrm{~m}$ petroleum ether

incusbation 18 hours at

$37^{\circ} \mathrm{C}$ in the dark

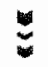

evaporation under $\mathrm{N}_{2}$ at $50^{\circ} \mathrm{C}$

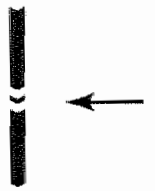

add $7 \mathrm{ml}$ aquadest. extract 3 times with $10 \mathrm{mi}$ diethylether

extract of methylated bile acids

in diethyllether

8

avaporation

2

deriwatisation

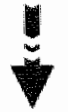

gaschnomatography

RGURE 1

Flow sheet of the method for the analysis of human faecal bile acids. 
Extraction of bile acids $7 \mathrm{ml}$ aqua dest is added to the residue and the methylated bile acids are extracted 3 times with $10 \mathrm{ml}$ diethylerher. After completion the diethylether is evaporated under a stream of nitrogen.

Derivatisation The methylated bile acids are converted into their trifuoroacetates by addition of $0.2 \mathrm{ml}$ trifluoroacetic anhydride to the residue and incubation in closed tubes for $20 \mathrm{~min}$ ar $37^{\circ} \mathrm{C}$.

Gas-liquid chromatography The rrifuoroacetic anhydride is evaporated and the residue dissolved in $0.2 \mathrm{ml}$ acetone. After injecring a $1 \mu \mathrm{l}$ sanple in the gaschromatograph, the bile acids are identified by comparing the retention times to those of reference bile acids and for one keto bile acid with a reference in the literature on a QF-1 column. The amount of bile acid in each sample is calculated by dividing the peak area of the bile acid by that of the internal standard, multiplied by the amount of internal standard added to the sample and corrected for the response factor of the flame ionizing detector.

Liquid scintillation counting In case recovery experiments with radiolabelled bile acids are performed, $0.1 \mathrm{ml}$ of the final acetone mixcure is transferred into a counting vial and evaporated. The residue is dissolved in a PPO/POPOP mixture $(5: 0.2 /$ litre $)$ in toluene and counted with external standardization for quench correction.

Determination of accuracy and precision The accuracy of the method is determined by measuring the recoveries of added reference bile acids to lyophilized faeces. Furthermore, the recovery of endogenously present DC and CDC in the stool of two patients (injected with ${ }^{14} \mathrm{C}$-labelled DC and CDC for kinetic studies) is determined by comparing radioactivity in the final acetone extracts with radioactivity measured after direct combustion of the faecal samples. The intra-assay precision is evaluated by calculating the CV values from the duplicate measurements of LC and DC in a control sample on different days. The inter-assay precision is calculated from the means of the duplicate measurements each day.

\section{Results}

In Fig. 2A, a GL chromatogram of a faecal sample with secondary bile acids is shown. Figure $2 B$ shows a GL chromatogram of a faecal sample in which a considerable quantity of primary bile acids are present. A reasonable separation of bile acids is achieved within $10 \mathrm{~min}$. Unfortunately on an OV-210 column isolithocholic acid (3B-hydroxy-5ß-cholanic acid) cannor be 


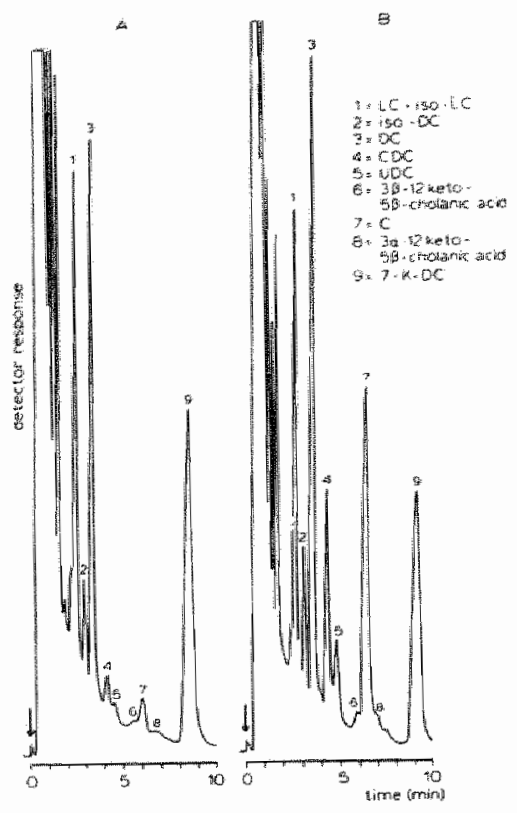

\section{FIGURE 2}

GLC of faecal bile acids in two different stools. (A) with secondary bile acids and a minor fracron of primary bile acids; (B) with secondary and primary bile acids.

TABLE 1

Recovery of radiolabelled reference bile acids added to faeces

\begin{tabular}{lll} 
No. of samples & Added bile acid & Recovery $(\% \pm$ SD) \\
\hline 10 & {$[24-14 \mathrm{CJLC}$} & $89.7( \pm 1.6)$ \\
12 & {$[24-14 \mathrm{CJDC}$} & $86.3( \pm 1.7)$ \\
10 & {$\left[24^{14} \mathrm{ClCDC}\right.$} & $85.8( \pm 2.6)$ \\
\hline
\end{tabular}

separated from lithocholic acid. In contrast, isodeoxycholic acid $(3 \beta, 120$;dilhydroxy-5B-cholanic acid) can be separated from deoxycholic acid. At the end of the run kero bile acids are eluted, of which 3B,12-kero-5B-cholanic acid and $3 \alpha, 12$-keto-5ß-cholanic acid can be identified. However, these keto bile acids are not always completely separated from cholic acid.

Recoveries of added radiolabelled reference bile acids are shown in Table 1 and proved to be sufficient and reproducible. Recoveries of two conjugared, four unconjugated and three sulfated bile acids, measured by GLC, are 
TABLE 2

Recovery of reference bile acids added to faeces determined by GLC

\begin{tabular}{lll}
\hline No. of samples & Added bile acid & Recowery $(\% \pm$ SD) \\
\hline 8 & LC & $95.8( \pm 5.0)$ \\
8 & DC & $95.5( \pm 6.5)$ \\
8 & CDC & $96.2( \pm 8.2)$ \\
4 & C & $92.8( \pm 4.0)$ \\
4 & GC & $85.5( \pm 0.7)$ \\
4 & TC & $84.5( \pm 7.7)$ \\
8 & SLC & $100.0( \pm 10.2)$ \\
8 & SDC & $101.3( \pm 3.0)$ \\
8 & SCDC & $98.0( \pm 5.4)$ \\
\hline
\end{tabular}

TABLE 3

Recovery of ${ }^{14} \mathrm{C}$ from faeces on 4 consecutive days a

\begin{tabular}{llll}
\hline Patient $\mathbb{1}^{b}$ & Radioactivity & Radioactivity & Recovery \\
{$[24-14 \mathrm{C}] \mathrm{DC}$} & after combustion & after extraction & $\%$ \\
& (disintegrations/g & (disintegrarions/g \\
& faeces) & faeces)
\end{tabular}

\begin{tabular}{lrrr}
\hline Day 1 & 1220 & 1040 & 85.2 \\
Day 2 & 8455 & 7336 & 86.7 \\
Day 3 & 6477 & 5601 & 86.5 \\
Day 4 & 10525 & 8257 & 78.4
\end{tabular}

Patient $2^{c}$

$\left[2,{ }^{14} \mathrm{C}\right] \mathrm{CDC}$

$\begin{array}{lrrr}\text { Day 1 } & 8419 & 7441 & 88.4 \\ \text { Day 2 } & 16193 & 12891 & 79.6 \\ \text { Day 3 } & 7077 & 6890 & 97.4 \\ \text { Day 4 } & 5076 & 4383 & 86.3\end{array}$

After intravenous injection of $\left[24^{14} \mathrm{CJDC}\right.$ or $\left[24^{14} \mathrm{C}\right] \mathrm{CDC}$ in two pationts.

b Patient with malignant adenoma of the colon and secondary bile acids in faeces.

"Patient with bile acid induced diarhoea and only primary bile acids in faeces.

sufficient and reproducible as is shown in Table 2. Recovertes of two endogenous bile acids (DC and CDC) were determined in two parients. In one patient (injected with $\left[24-{ }^{14} \mathrm{C}\right] \mathrm{DC}$ ) only secondary bile acids were present in the stool; in the other patient (injected with [24-1/4]CDC) only primary bile acids were detected in the stool. Faeces was collected during four days. Combusrion of faeces in a sample oxidator ( $\pm 1 \mathrm{~g}$ wet faeces) was used as a reference. The efficacy of the combustion had been determined by adding a 
known amount of $\left[24^{-14}\right] \mathrm{DC}$ to wet fresh voided faeces. The recovery of the ${ }^{14} \mathrm{CO}_{2}$ was $96.7 \pm 6.9 \%(\mathrm{n}=5)$ of the calculated radioactivity. After extraction of the faeces of the two patients, the recovery of DC was $84.2 \pm 3.9 \%$ (mean $\pm S D)$ and of CDC $87.9 \pm 7.3 \%$ (mean \pm SD), compared to combustion in the sample oxidator, as is shown in Table 3 . The intra-assay precision for the determination of the most prominent faecal bile acids $\mathrm{LC}$ and $\mathrm{DC}$ was 2.8 and $4 \%$, respectively. The inter-assay precision was $9.0 \%$ and $7.2 \%$ for $L C$ and DC, respectively.

\section{Discussion}

Most extraction procedures of faecal bile acids are complex, use several purification steps and are time-consuming. The Grundy method (3), which is regarded as our reference procedure does not allow the measurement of sulfated bile acids and some keto bile acids. Furthermore, the strong alkaline hydrolysis which is used, can give rise to artefacts (18), like the formation of unsaturated derivatives of sulfated chenodeoxycholic acid (23). In our method alkaline hydrolysis is replaced by enzymatic deconjugation. The conjugated bile acids are hydrolysed sufficiently.

Bile acids are extracted from the particulate matter by refluxing in an alkaline methanolic solution. We use methanol instead of ethanol to prevent the formation of bile acid echylesters. The extraction of endogenous DC and CDC is acceptable by refluxing for two hours. The extraction efficiency of endogenous LC could not be detected unfortunately. However, Podesta et al extracted $99 \%$ of the radioactivity in faeces of a healthy volunteer, who ingested $\left[24^{-14} \mathrm{C}\right] \mathrm{CDC}$, by refluxing $2 \mathrm{~h}$ in an alkaline ethanolic solution (9). Since CDC is normally almost completely dehydroxylated to LC (+isoLC) in the large bowel, the radioactivity would be present in this last fraction.

After the saponification step neurral steroids must be extracted with petroleum ether, because coprostanon can interfere with the gas liquid chromatographicanalysis on OV-210. This compound is eluted at the same time as (iso) lithocholic acid.

The extent of sulfation of bile acids in human faeces is still debated. Some investigators found up to $40 \%$ sulfated bile acids in human faeces $(9,10)$, whereas, others found only a minor fraction $(<5 \%)$ sulfared bile acids in human stool $(11,12,14,15)$. Because sulfated bile acids (mainly sulfated lithocholic acid) can be present in human faeces we decided to carry out a 
solvolysis procedure. The solvolysis procedure, originally described by Javint (19) and applied to serum by Cantafora et al (20), seemed appropriate to use for faecal bile acids. An advantage of the method is the simultaneous methylation of the free bile acids that occurs in the acidified anhydrous mixture (21). To split CDC-7-sulfate incubation overnight at $37^{\circ} \mathrm{C}$ is warranted (22). We have tried to measure the amount of unsulfated bile acids by extraction of the bile acids after saponification with diethylether at an acidic $\mathrm{pH}$. However, in accordance with the observations of Pageaux et al (23) added sulfolithocholic acid was partly solvolysed during this procedure. Even when the extraction was performed at a lower temperature or higher $\mathrm{pH}$ partial solvolysis took place. So, quantitative measurement of unsulfated bile acids was not possible.

Recently, a rapid extraction procedure for the determination of faecal bile acids was published (8). Recoveries, however, were measured qualitatively using thin-layer chromatography or quantitatively by enzymatic determination.

In conclusion, the proposed method for the determination of the major bile acid metabolises in human stool by GLC is rapid and does allow the determinarion of a considerable number (about 48 ) of faecal samples in 3 days. The simultaneous solwolysis and methylation of the bile acids after saponification is of particular advantage. Conjugated and sulfated bile acids, which may be present in human faeces, are included in the determination of the individual bile acids.

\section{Acknowledgements}

This study was supported by The Netherlands Cancer Foundarion (NUKC 78-4 and 83-10), The Netherlands Organisation for Advancement of Pure Research ( $Z$ WO 94-38) and the University of Nijmegen.

The authors are grateful for the technical assistance of Mrs. A. van Schaik at the beginning of the study.

\section{References}

1. HiLl MJ, Drasar BS, Williams $\mathbb{R E O}$, er al. Faecal bile acids and clostridia in patients with cancer of the large bowel. Lancet 1975; i: 535-539.

2. Cohen Bl, Raiche RF, Deschner EE, et al. Effect of cholic acid feeding on N-methyl N. nitroso-urea induced colonic tumours and cell kinerics in rats. I Wat Cancer Inst 1980; $64: 573-578$. 
3. Grundy SM, Ahrens Jr EH, Metrinen TA. Quancitarive isolation and gas-liquid chromatographic analysis of total fecal bilc acids. J Lipid Res $1965 ; 6: 397-410$.

4. Eneroth $P$, Gordon $B$, Ryhage $R$, Sjowall $]$. Idenutication of mono- and dihydroxy bile acids in human feces by gas-liquid chromatography and mass spectrometry. If Lipid Res $1966 ; 7: 511-523$

5. Encroth P, Gordon B, Sjövall I. Characterization of misubstituted cholanic acids in human feces. I Lipid Res 1966; 7: 524-530.

6. Evrard $\mathbb{E}$, Janssen $G$. Gas-liquid chromatographic determination of human fecal bile acids. I Lipid Res 1968; 9: 226-236.

7. Roseleur OJ, Van Gent CM. Alkaline and enzymatic hydrolysis of conjugated bile acids. Clin Chim Acta 1976: 66: 269-272.

8. Van den Ende A, Radeeker CE, Mairnhu WM, Van Zanten AP. Improved extraction procedure for determination of bile acids in faeces. Clin Chim Acta 1982: 121:95-109.

9. Podesta MT, Murphy GM, Dowling RH. Measurement of faecal bille acid sulphates. J Chromattogr 1980; 182:293-300.

10. Salwioli G. Salat R. Faecal bile acid loss and bile acid pool size during short-term treatment with ursodeoxycholic and chenodeoxycholic acid in patients with radiolucent gallstones. Gur 1979; 20:698-704.

11. Islam MA, Raichr RF, Cohen BI. Isolation and quantitation of sulfared and unsulfated sterouds in human feces. Anal Biochen 1981; 112:371-377.

12. Mclunckin B, Fromm R, Sarva P, Amin P. Factors in the mechanism of diarthea in bile acid malabsorption: fecal $\mathrm{pH}$, a lkey determinant. Gastroenterology 1981; 80: 1454-1464.

13. Van Fazssen A, Huibregts AWM. Letter to the editor. J Lipid Res 1982; $23: 508$.

14. Tanida N, Hikase $Y$, Shimoyaura T, Setchell KDR. Comparison of faecal bile acid profilles berween patients with adenomatous polyps of the large bowel and healthy subjecrs in Japan. Gut 1984: 25:824-832.

15. Hikasa $Y$, Tanida $N$, Ohno $T$, Shimoyana T. Faecal bile acid profiles in panients with large bowel cancer in Japan. Gut 1984; 25: 832-838.

16. Setchell KDR, Lawson AM, Tanida N, Sjövall ]. General methods for the analysis of metabolic profilles of bile acids and related compounds in feces. I Lip"d Res 1983; 24: 1085-1100.

17. Griffith MH, Mallinson A. A furnace for combustion of biological material containing tritium and carbon-14 labeled compounds. Anal Biochem 1968; 2: 465-473.

18. Lepage $G$, Fontaine $A$, Roy $\mathrm{CC}$. Vulnerability of keto bile acids to alkaline hydrolysis. I Lipid Res 1978; 19: 505-509.

19. Javirt $\mathbb{N B}$, Lawy U. Serum chenodeoxycholate in neonatal liver disease. In: Matern $S$, Hackenschrnidt J, Back P. Gerok W, eds. Advances in bile acid research. Sturgart-New York: FK Schattauer Verlag, 1974: 123.

20. Cancufora A, Angelico M, Atrilt AF, Ersoli L, Copocaccia L. An improved gaschromatographic method for the determination of sulfared and unsulfated bille acids in serum. Clin Chim Acra 1979; 95: 501-508.

21. Shaw $\mathbb{R}$, Elliot WH. Bile acids LV. 2,2-Dimethoxypropane: an esterifying agent preferred to diazomethane for chenodeoxycholic acid. J Lipid Res 1978; 19:783-787.

22. Cohen BH. Budai K, Javitt NB. Solwolysis of chenodeoxycholic acid sulfares. Steroids $1981 ; 37: 621-626$.

23. Pageaux Jf:, Duperray $B$, Anker $\mathbb{D}$, Dubois $M$. Bile acid sulfates in serum bile acids determination. Steroids $1978 ; 34: 73-88$. 


\section{Chapter 3}

\section{Bile acids, neutral steroids, and bacteria in faeces as affected by a mixed, a lacto-ovovegetarian, and a vegan diet}

Arendina van Faassen, Jan Bol, Wim van Dokum, Nicolaas A. Pikaar, Theo Ockhuizen and Rudolph J.J. Hermus

Based on: Am. J. Clin. Nutr. 46 (1987) 962-967

\section{Abstract}

In a metabolic ward 12 healthy male subjects consumed mixed Western (M), lacto-ovovegetarian (L), and vegan (V) diets in a randomized order for $20 \mathrm{~d}$ each. The concentrations of deoxycholic acid, isolithocholic acid, and total bile acids in 4-d composites of faeces on the $\mathrm{L}$ and $\mathrm{V}$ diets were significantly lower than on the $M$ diet. The chenodeoxycholic-to-isolithocholic plus lithocholic acid ratio was significantly higher on the $\mathrm{V}$ diet. The concentrations of coprostanol and of coprostanol plus cholesterol were highest on $M$ diet and lowest on $\mathrm{V}$ diet. The number of faecal lactobacilli and enterococci on the $\mathrm{V}$ diet was significantly lower than on the $\mathrm{M}$ or the $\mathrm{L}$ diets. This study showed a decrease in the concentration of faecal (secondary) bile acids by the $\mathrm{L}$ and the $\mathrm{V}$ diets and an alteration of the faecal Flora composition by the $\mathrm{V}$ diet.

\section{Introduction}

In epidemiological studies the mortality of colorectal cancer has been associated with the diet. For omnivores a higher mortality is reported for colorectal cancer than for vegetarians $(1,2)$ and vegans (3). A high-fat low-fiber diet is associated with a high risk of developing colorectal cancer (4). 
However, lifestyle factors other than the diet also may be responsible for the difference in colorectal cancer mortality between groups with different dietary habits. To determine the role of the diet in developing colorectal cancer, many studies have been perfortned on the influence of fat, fiber, and meat on faecal characteristics, which also are associated with this form of cancer $(5,6)$. We studied the combined effect of three types of habitual diets, ie, mixed Westem $(M)$, lacto-ovovegetarian (L), and vegan ( $V$ ) diets, on faecal concentrations of bile acids, neutral steroids, and bacteria.

\section{Materials and methods}

\section{Subjects and diets}

The study was a diet-controlled, Latin-square design involving 12 male Caucasians, aged 20-27 y, selected from a pool of volunteers because of general health condition as assessed by hematological and clinical examinarion, dictary habits (nonvegetarian), and trustworthiness. Two identical experiments were carried out with six volunteers each. They were housed in the institute's controlled metabolic ward and continued their normal daily routine. A working group responsible for human nutrition studies performed at the institute approved this study.

After an adaptation period of $8 \mathrm{~d}$ on a mixed diet, the three experimental diets were provided in randomized order for $20 \mathrm{~d}$ each. The energy and nutrient contents of the diets were determined as described earlier (7). The mean values of four daily samples of each diet are shown in Table 1 . The nutrient composition of the diet was based on a descriptive study of the nutritional status of Dutch lacto-ovovegetarians and omniwores (8) aged 18-30 y. The diets differed in the amount and composition of fat and dietary fiber and in composition of the protein. The percentage of meat protein was zero in the $\mathrm{L}$. and $V$ diets and 46 in the $M$ diet. The percentage of milk protein was zero in the $V$ dier and 28 and 54 in the $M$ and L diets, respectively. The percentage of vegetable protein in the $V, L$, and $M$ diets were 100,46 , and 26 , respectively. The food was prepared in the diet kitchen; portions were weighed to the nearest gram and deep frozen if necessary. Sugar, soft drinks, and jelly were supplied when the body weight, as measured in the adaptation period, had decreased $>2 \%$.

\section{Faecal steroids}

Faeces were collected at $-20^{\circ} \mathrm{C}$ using deep-freeze toilets (9). Composites of 4-d collections were thawed overnight at room temperature, homogenized, 


\begin{tabular}{llll}
\hline & $\begin{array}{l}\text { Mixed } \\
\text { diet } \\
(\mathrm{M})\end{array}$ & $\begin{array}{l}\text { Lacto- } \\
\text { ovovegetarian } \\
\text { diet (L) }\end{array}$ & $\begin{array}{l}\text { Vegan } \\
\text { diet } \\
\text { (V) }\end{array}$ \\
\hline Metrabolizable energy (M) & 11.8 & 12.9 & 13.0 \\
Metabolizable energy (kca) & 2820 & 3080 & 3110 \\
Protein (energy \%) & 17 & 16 & 17 \\
Far (energy \%) & 38 & 32 & 33 \\
Available cabohydrates (energy \%) & 45 & 52 & 50 \\
Linoleic acid (energy \%) & 5 & 1.1 & 17 \\
Sarurated fatry acids (energy \%) & 1.3 & 14 & 8 \\
Neutral detergent dietary fiber (g) & 22 & 28 & 40 \\
Hemicellulose (g) & 11 & 13 & 22 \\
Cellulose (g) & 7 & 10 & 6 \\
Lignin (g) & 4 & 5 & 12 \\
\hline
\end{tabular}

and frozen in portions. From a thawed portion $0.5 \mathrm{~g}$ was weighed into a glass-stoppered centrifuge tube. The concentration of faecal steroids was measured by a modification of the method for faecal bile acids as described earlier (10). Enzymaric deconjugation was omitted because in healthy subjects most faecal bile acids are deconjugated (11). Hyodeoxycholic acid and $5 \alpha-$ cholestane (Steraloids Inc, Wilton) were used as internal standards for the determination of acidic steroids (bile acids) and neutral steroids (cholesterol and vegetable steroids such as B-sitosterol), respectively. Sulfated steroids (12) were split by addition of $7 \mathrm{ml}$ 2,2-dimethoxypropane per $\mathrm{ml}$ faecal water, acidification to $0.1 \mathrm{~N} \mathrm{HCl}$, and incubation overnight at $37^{\circ} \mathrm{C}$. After neurralization with NAOH in methanol, the anhydrous mixture was evaporated under a nitrogen stream. Esters were hydrolysed and bile acids were extracted from the particulate matter with a $76 \%$ (vol/vol) methanolic solution containing $\mathbb{N} \mathrm{NaOH}$. The neurral steroids and fatty acids were extracted with petroleum ether after acidifying the mixture with acetic acid to $\mathrm{pH}$ 4. The neutral steroids were trifluoracetylated after evaporation. Bile acids were extracted with diethyl ether after acidifying to $\mathrm{pH}<1$ with concentrated $\mathrm{HCl}$ and then methylated in methanol-2,2 dimethoxypropane-concentrated $\mathrm{HCl}, 10: 10: 1$ (vol/vol) by incubating overnight at room temperature in the dark. After evaporation of the reagents, the methylated bile acids were trifluoracetylated. Neutral steroid trifluoracetates and bile acid methyl ester trifluoracetylates were analyzed on a $25 \mathrm{~m} \times 0.45 \mathrm{~mm}$ id capillary glass column coated with $0.4 \mu \mathrm{m}$ CP Sil 5 (Chrompack, Middelburg, the Netherlands) using a Packard Becker 420 gas chromatograph (Packard Instrument Co, Inc, Downers Grove, IL) with a solid injector. Operation and conditions were as 
follows: column owen temperature $224^{\circ} \mathrm{C}_{;}$injector port temperature $235^{\circ} \mathrm{C}$; hydrogen flame detector $260^{\circ} \mathrm{C}$; carrier flow of helium, $8 \mathrm{ml} / \mathrm{min}$; and split-flow $15 \mathrm{ml} / \mathrm{min}$. Peaks were identified by comparing their relative retention times with those of pure standards. The amount of each steroid was calculated from the relative peak height andamount of internal standard used. Peak height of each steroid was corrected for detector response. Samples from the three different dietary periods of one person were processed simultaneously.

\section{Faecal bacteria}

The microbial composition of two faecal samples taken on different days during the last week of a dietary period was determined. Immediately after defaccation, subsamples from different regions of the stool were pooled in a prereduced transport medium (13). Prereduced media and an anaerobic glovebox were used for the analyses of anaerobic microorganism. Total anaerobes and clostridia were determined on blood agar and SuaP-agar (14), respecrively. Bifidobacteria were enumerated on bifidobacteria agar and Bacteroides species on KVL agar (15). Isolates were confirmed by gas chromatographic analysis of the volatile fatty acids and lactic and succinic acids in culture broths.

Ambient conditions were used for analysis of aerobic microorganisms. The total number of aerobes, enterobacteriaceae, lactobacilli, and enterococci were estimated using tryptone soya glucose agar (TSGA) (CM 131, Oxoid Ltd, Hants, UK, supplemented with $1 \%$ glucose), violet red bile glucose (VRBG) (Oxoid CM 485), Rogosa (5413, Merck, Amsterdam, the Netherlands), and kanamycin milk agar (13), respectively.

Statistical analysis

Analysis of variance was applied to detect differences in faecal characteristics during the dietary periods and the two experiments. The effects of the diets were correcred for possible residual influences of one preceding experimental diet period (16). Variables that were not normally distributed, even after rtansformation, were analyzed using the signed-rank test.

\section{Results}

All 12 subjects completed the study and adhered faithfully to the dietary regimen. There were no reports of any health problems. No statistically 
TABLE 2

Concentrations of faecal bile acids during mixed (M), lacro-ovovegerarian (L), and vegan (W) periods

Concentration in $\mu$ mol/g wet weight:

\begin{tabular}{llll}
\cline { 2 - 4 } Bule acid & $\mathrm{M}$ & $\mathrm{L}$ & $\mathrm{V}$ \\
\hline Deoxycholic acid (DC) & $1.95(0.8-3.2)$ & $1.52(0.6-2.7)^{*}$ & $1.29(0.2-2.1)^{*}$ \\
Isolithocholic acid (ILC) & $0.90(0.5-1.3)$ & $0.69(0.1-1.1)^{*}$ & $0.52(0.1-0.8)^{*}$ \\
Lithocholic acid (LC) & $1.36(0.1-2.0)$ & $1.14(0.1-1.7)$ & $1.08(0.1-1.9)$ \\
Chenodeoxycholic acid (CDC) & $0.15(0.0-0.4)$ & $0.14(0.0-0.4)$ & $0.17(0.0-0.3)^{*}$ \\
Ursocholic acid (UDC) & $0.13(0.1-0.3)$ & $0.15(0.0-0.3)$ & $0.14(0.1-0.2)$ \\
7-ketodeoxycholic acid (7-K-DC) $0.00(0.0-0.1)$ & $0.00(0.0-0.1)$ & $0.00(0.0-0.1)$ \\
7-ketolitbocholic acid (7-K-LC) & $0.21(0.0-0.5)$ & $0.17(0.1-0.5)$ & $0.13(0.0-0.3)$ \\
DC+ILC+LC+CDC+UDC+7- & & & \\
K-DC+7-K-LC & $4.61(3.0-7.3)$ & $3.77(2.1-5.7)^{*}$ & $3.34(1.0-5.2)^{*}$ \\
CDC/LC + LC & $0.06(0.0-0.2)$ & $0.10(0.0-0.5)$ & $0.15(0.0-0.5)^{*}$
\end{tabular}

Mean walues wich minimum and maximum values in parentheses.

* Significantly different from their respective values in the $M$ period $(p<0.05)$.

* Significantly different from their respecive values in the $L$ periad $(p<0.05)$.

significant residual effects of the preceding diet period and no differences in results between the two experiments were observed. Therefore, results are given for the 12 subjects.

Faecal bile acid concentrations were influenced by the diets (Table 2). The faecal concentration of deoxycholic acid (DC), isolithocholic acid (ILC), and the sum of DC, ILC, lithocholic acid (LC), chenodeoxycholic acid (CDC), ursodeoxycholic acid (UDC), 7-ketodeoxycholic acid (7-K-DC), and 7ketolithocholic acid $(7-\mathrm{K}-\mathrm{LC})$ decreased significantly $(\mathrm{p}<0.05)$ during the $\mathrm{L}$ and $V$ diets. During the $V$ diet, the concentration of $D C$ was lower and that of CDC higher than during the L diet. For ILC there was a trend $(0.05<\mathrm{p}<$ a. 1) to a lower concentration on the $V$ diet compared with the $L$ diet and for LC a trend to a lower concentration on the $\mathrm{V}$ diet compared with the $\mathrm{M}$ diet. The CDC:(ILC + LC) ratio, which is a measure for the primary-to-secondary bile acids ratio, was significantly higher $(p<0.05)$ during the $V$ diet than during the $M$ and $L$ diets.

The concentrations of faccal cholesterol and coprostanol and their sum were significantly lower $(\mathrm{p}<0.05)$ during the $\mathrm{V}$ diet than the $\mathrm{L}$ diet (Table 3). The concentrations of coprostanol and of cholesterol plus coprostanol on the $L$ diet was lower than the $M$ diet; for cholesterol there was a trend $0.05<p<$ $0.1)$ to a lower concentration on the $L$ diet than on the $M$ diet. The cholesterol-to-coprostanol ratio, which is a measure of the cholesterol 
TABLE 3

Concentrations of faceal cholesterol and coprostanol during mixed (M), lacro-ovovegetarian (L) and wegan (V) periods

\begin{tabular}{llll}
\hline & \multicolumn{3}{c}{ Concentration in $\mu$ mol/gwer weight } \\
\cline { 2 - 4 } Neutral steroid & $M$ & $L$ & $V$ \\
\hline Coprostanol & $9.50(1.6-20.7)$ & $6.67(2.8-11.4)^{*}$ & $3.62(1.1-9.6)^{*}$ \\
Cholesterol & $2.17(0.2-4.8)$ & $1.60(0.2-4.0)$ & $0.91(0.1-2.5)^{*}$ \\
Cholesterol + coprostanol & $11.68(3.8-24.5)$ & $8.27(3.2-15.0)^{*}$ & $4.53(1.8-12.1)^{*}$ \\
Cholesterol/Coprostanol & $0.39(0.0-2.2)$ & $0.23(0.0-0.4)$ & $0.28(0.1-0.7)$ \\
\hline
\end{tabular}

Mean values with minimum and maximum values in parentheses.

- Significandy different from their respective values in the $M$ period $(p<0.05)$.

\#ignificantly different from their respective values in the $L$ period $(p<0.05)$.

\section{TABLE 4}

Faccal chalesterol-to-coprostanol and 24-ethyl cholesterol ( $\beta$-sirosterol)-to-24-echyl coprostanol ratios of one wolunteer during successive mixed $(\mathrm{M})$, vegan $(\mathrm{V})$, and lacto-ovovegetarian (L) periods

\begin{tabular}{lccccccccc}
\hline Ratio & $\mathrm{M}_{1}$ & $\mathrm{M}_{2}$ & $\mathrm{M}_{3}$ & $\mathrm{~V}_{1}$ & $\mathrm{~V}_{2}$ & $\overline{\mathrm{V}_{3}}$ & $\mathrm{~L}_{1}$ & $\mathrm{~L}_{2}$ & $\mathrm{~L}_{3}$ \\
\hline $\begin{array}{l}\text { Cholesterol:Coprostanol } \\
\text { 24-ethylcholesterol: }\end{array}$ & 2.3 & 2.2 & 2.2 & 2.0 & 0.3 & 0.3 & 0.2 & 0.3 & 0.2 \\
\begin{tabular}{l} 
24-ethyl coprostanol \\
\hline
\end{tabular} & 2.8 & 3.4 & 2.9 & 1.8 & 0.10 & 0.1 & 0.1 & 0.1 & 0.1 \\
\hline
\end{tabular}

hydrogenating activity of the faecal flora, did not change significantly. For one volunteer, however, lower cholesterol-to-coprostanol and ethyl cholesterol (B-sitosterol, a vegetable steroid)-to-ethyl coprostanol ratios were found after changing from the $M$ to the $V$ and then to the $L$ diets (Table 4). In the first 4 -d composite of faeces of this volunteer on the $V$ diet, the rarios still were similar to the ones on the $M$ diet.

The mean counts of anaerobic microorganisms in the faeces during the different diecary periods differed only slightly (Table 5). The $V$ and $\mathrm{L}$ diets reduced clostridia counts to some extent in eight wolunteers. The numbers of lactobacilli and enterococci were significantly $(\mathrm{p}<0.05)$ lower on the $\mathrm{V}$ diet compared with the $L$ diet. The number of lactobacilli was significantly $(p<$ 0.05 ) higher on the $\mathrm{M}$ diet than on the $\mathrm{V}$ diet. In some individuals the differences were $>2 \log$ units. 
Number of facal bacteria during nimed (M), lacco-ovovegerarian (L), and vegan (V) periods

Number (log viable cound/g wet weight)

\begin{tabular}{|c|c|c|c|c|c|c|}
\hline \multirow[b]{2}{*}{ Frecal bacteria } & \multicolumn{2}{|l|}{$M$} & \multicolumn{2}{|l|}{$\mathrm{L}$} & \multicolumn{2}{|l|}{$\mathrm{V}$} \\
\hline & Mean & Range & Mean & Range & Mean & Range \\
\hline Totall anaerobes & 9.9 & $9.0-10.8$ & 9.9 & $9.4-10.3$ & 99 & $8.9-110.6$ \\
\hline Clostridia & 7.9 & $6.8-8.8$ & 7.5 & $6.7-8.3$ & 7.4 & $6.5-8.4$ \\
\hline Bifidobacteria & 8.8 & $<7-10.3$ & 8.7 & $7.7-9.5$ & 8.9 & $<7-10.1$ \\
\hline Bacteroides & 9.5 & $9.0-10.5$ & 9.5 & $9.2-10.1$ & 9.6 & $8.6-9.9$ \\
\hline Total aerobes & 6.9 & $6.2-7.7$ & 7.2 & $5.6-8.5$ & 67 & $5.7-8.4$ \\
\hline Enterobacteriaceae & 6.4 & $4.9-7.7$ & 6.6 & $5.0-8.4$ & 6.0 & $<4-8.4$ \\
\hline Enterococci & 5.3 & $3.5-6.4$ & 5.8 & $4.4-7.3$ & $5.1^{\circ}$ & $<3.6 .7$ \\
\hline Lactobacilli & 4.9 & $3.2-6.4$ & 5.4 & $4.9-6.7$ & $4,1^{4}$ & $<3.6 .4$ \\
\hline
\end{tabular}

"Significanty different from their respective walues in the $L$ period $(p<0.05)$.
"Significantly ditterent from their respective values in the M period $(p<0.05)$.

\section{Discussion}

The aim of this study was to measure the influence of habituall diers on faecal characteristics that have been associated with the risk of developing colorectal cancer, ie, the faecal concentrations of bile acids, neutral steroids, and bacteria. The concentrations of the secondary bile acids DC and ILC and also of the sum of the measured bile acids, which are positively associated with the risk of colorectal cancer $(17,18)$, was highest on the $\mathrm{M}$ diet. This diet provided. the highest amount of fat and meat and the lowest amount of dietary fiber. A higher excretion of bile acids and a lower faecal wet weighe (19) was found on this diet than on the $L$ and $V$ diets, causing the higher bile acid concentration.

The enhancing effect of fat on the DC concentration was described for beef far (20). The lowering effect of dietary fiber on the concentrations of total bile acids was described for fiber from bran $(7,21)$, for a fiber rich diet (22) and for vegetarian diets $(3,23,24)$. The DC concentration was lower on the $V$ diet than on the $L$ dier. The fat content of both diers was equal and so were the resulting faecal weights. However, the $V$ diet contained no milk products and more polyunsaturated fatty acids than the $\mathrm{L}$ diet. The hypothesis has been put forward that milk products increase the excretion of DC because of 
gastrointestinal binding to insoluble calcium phosphare (25). Polyunsaturated farty acids were found to increase the excretion of faecal bile acids only, at high cholesterol levels of the diet (26). The $V$ diet contained almost no cholesterol.

The CDC:(ILC + LC) (primary-to-secondary bile acid) ratio, which is negatively associated with the risk of colorectal cancer $(3,24)$, was highest on the $\mathrm{V}$ diet. The ratio of the other primary bile acid $(\mathrm{C})$ to its secondary products (IDC $+\mathrm{DC}$ ) could not be determined because of the poor separation of $\mathrm{C}$ and DC in $30 \%$ of the chromatograms. A higher ratio has been described after consumption of a diet rich in fiber (27). The $\mathrm{V}$ diet contained the highest amount of dietary fiber, especially of fermentable hemicellulose. The higher ratio of CDC:(ILC + LC), mainly because of the higher concentration of CDC, may be caused by a lower $7 \alpha$-dehydroxylating activity of faecal bacteria because faecal $\mathrm{pH}$ was lower on the $\mathrm{V}$ diet (28. 29). It should be realized however that the secondary-to-primary bile acid ratio is not the only variable determining the concentration of secondary bile acids. The concentration of primary bile acids is even more important.

The concentration of faecal cholesterol plus coprostanol, which has been positively associated with the risk of colorectal cancer in epidemiological studies (4), but which promoting effect on chemically induced colon carcinogenesis is uncertain (30), was highest on $\mathrm{M}$ diet and lowest on $\mathrm{V}$ diet. The concentration of coprostanone could not be measured because of its degradation during the analytical procedure. However, this compound is a minor bacterially degraded product of cholesterol (31). "The lower amount of fat and the higher amount of dietary fiber in the $L$ diet compared with the $M$ diet will be responsible for the lower concentration of cholesterol plus coprostanol in the faeces during the $L$ diet, and the almost zero amount of cholesterol in the $V$ diet for the lowest faecal concentration of cholesterol plus coprostanol on this diet $(18,26,32,33)$.

The cholesterol-to-coprostanol ratio, which has been reported to be higher in persons belonging to groups at high risk of colon cancer (34), did not change in most of the subjects. Only one volunteer, who was a low converter of cholesterol and ethyl cholesterol ( $B$-sitosterol)(35) on the M diet, became a high converter when consuming the $V$ and $L$ diets. The reason for this may be his rapid gastrointestinal transit on the $M$ diet, which slowed down on the $L$ and $V$ diets (36).

The anaerobes-to-aerobes ratio, which has been shown to be higher in individuals with an increased risk of colorectal cancer (37), did not differ on the three diets. It should be realized, however, that in this ratio organisms with 
potiential totally different metabolism are combined and therefore this ratio probably is not relevant in bowel flora studies. Total numbers of faecal enterococci and llactobacilli were clearly reduced on the $\mathrm{V}$ diet compared with the other diets. For some volunteers a difference of $>2 \mathrm{log}$ units was observed. A possible explanation may be the increased inhibitory action of bile acids at the lower $\mathrm{pH}$ value on this diet (38). Until now nonextreme experimencal diets have been reported to cause only minor changes in faecal flora composition $(6,39)$.

In a low-risk population (Finland) a greater number of faecal lactobacilli was reported (40). The Finnish diet contains a large amount of milk products (41) and, therefore, is comparable to our $\mathrm{L}$ diet, on which we found a higher number (as compared with the $M$ diet) of faecal lactobacilli in 8 of 12 volunteers.

This study shows a decrease of the concentration of faecal (secondary) bile acids by the $\mathrm{V}$ and $\mathrm{L}$ diets. It also was observed that the composition of the faecal flora was changed after consuming the $V$ diet for 2 wk.

\section{Acknowledgements}

We wish to thank Jacques T.N.M. Thissen, MSc, and Michel Wedel, MSc, for statistical support; Miss A. Wesstra for composing the diets; our subjects for eating the diets; Mr L. van Ginkel for the assays of faccal bile acids and neutral steroids; and Mr E.J. van Overeem for the determination of faecal bacteria.

\section{References}

1. Philips RL, Kuzma JW, Beason, Lorz T. Influence of selection venus lifistyle on risk of Fatal cancer and cardiovascular disease among Seventh-Day Adventists. Am J Epidemiol $1980 ; 112: 296-314$.

2. Kinlen Lf, Hermon $C_{3}$ Smith PG. A proportionate study of cancer mortality among members of a vegetarian society. Br J Cancer 1983,48:355-61.

3. Reddy BS, Wynder EL. Large bowel carcinogenesis: fecal constituents of populations with diverse incidence rates of colon cancer. J Nad Cuncer Inst 1973;50:1437-42.

4. Zaridze DG. Envinonmental etiology of large-bowel cancer. I Nat Cancer Inst $1983 ; 70: 389-400$.

5. Kay RM. Effects of diet on the fecal excretion and bacterial modification of acidic and neutral steroilds, and implications for colon carcinogenesis. Cancer Res 1981;41:3774-7.

6. Hill MJ. Diet and the human intestinal bacrerial flora. Cancer Res 1981;41:3778-80. 
7. van Dokkum $W$, Pikaar NA, Thissen ITNM. Physiological effects of fibre-rich types of bread. 2. Dietary fibre from bread: digestibiliry by the incestinal micro flora and warerholding capacity in the colon of human subjects. BrJ Nutr 1983;50:61-74.

8. Rookux MA, PJey LMH, van der Beck EJ, er al A compararive sewdy of nutrirional status and physical performance of $18-30$ yr old lacto-owo vegetarians and omnivorics. Voeding $1983 ; 44: 24655$ (abstr English).

9. Ghoos $Y$, wan Trappen $G$. Clean collection and manipuarion of stools. Lancet $1977 ; 1: 884-5$.

10. van Faassen A, Nagengabt FM, Hectors $M$. et al. Determination of indiwidual human faccal bille acids by gas hiquid chromarography after enxymatic deconjugarion and simultaneous solvolysis and methylation using dimethoxypropane. Clin Chim Acta 1985;152: 231.9.

11. Setchell KDR, Lawson AM, Tanida N, Sjövall J. General methods for the analysis of merabolic profdes of bile acids and related compounds in feces. J Lipid Res $1983: 24: 1085-100$.

12. Islam MA, Raicht RF, Cohen B1. Isolation and guantitation of sulfated and unsulfated steroids in human feces. Anal Biochem 1981;112:371-7.

13. Var der Wiel-Korstanje IAA. Bifidobacterien en enterococen in de darmflora van de mens. Utrecht: Drukkerij Elinkwijk, 1973.

14. Mossel DAA, De Wart J. The enumeracion of clostridia in foods and feeds. Ann Inst Pasteur Lille 1968;19:13-27.

15. Sutter VL, Vargo VL, Finegold SM. Wadsworth anacrobic bacteriology manual. 2 nd ed. Los Angeles, CA: Wadsworth Hospital Center, Veterans Administration and the Department of Medicine, UCLA, 1975.

16. Cochran WG, Cox GM. Experimental designs. 2nd ed. London: John Wiley and Sons, 1957.

17. Hill MI. The aetiology of colorectal cancer. Clin Gastroenterol 1980;S:297-309.

18. Coben Bl, Raichr RF. Effects of bille acids on colon carcinogenesis in rats treated with carcinogens. Cancer Res 1981;41:3759-60.

19. van Faassen A, van Dokkum W, Pikaar NA, Hermus RJJ. The influence of a lacrovegetarian, a vegan and a mixed diet on colonic function of man: preliminary results. In: Galli $\mathrm{G}$, Bosisio $\mathrm{E}$, eds. Liver, nutrition and bile acids, New York: Plenum Press, $1985: 249-52$.

20. Reddy BS, Hanson D, Mangat $S$, et al. EfFect of high-fat high-beef diec and of mode of cooking of beef in the diet on fecal bacterial enzymes and fecal bile acids and neurtal strels.) Nut 1980;110:1880-7.

21. Cummings JH, Hill MJ, Jivraj T, Houston $H$, Branch WJ, Jenkins DJA. The effect of mear protein and dietary fiber on colonic function and metabolism. I Changes in bowel habit, bille acid excrerion, and calcium absorption. Am II Clin Nutr 1979;32-2086-93.

22. Kretch MJ, Crawford L, Calloway DH. Some aspects of bile acid and urobilinogen excretion and fecal elimination in men given a rural Guatemalan diet and egg formulas with and withour added oat bran. Am J Clin Nutr 1979;32:1492-6.

23. Aries VC, Crowther JS, Drasar BS, Hill M], Ellis FR. The efreet of a strict wegetarian dien on the faccal Mora and faccal steroid concenuation. I Pathol 1971;10354-5.

24. Turiman $N$, Goodman GT, Jaeger $\mathbb{B}$, Nair $\mathbb{P}$. Diet, nucrition intake and metabolism in populations at high and low risk for colon cancer. Merabolism of bile acids. Am I Clin Nutr $1984,40: 937-41$.

25. van der Meer R, de Vries HT. Differential binding of glycine-and taurine-conjugated bile acids to insoluble calcium phosphace. Biochem ] 1985;229:265-8. 
26. Oh SY, Monaco PA. Effect of dietary cholesterol and deguee of hat unsatumcion on plasma lipid levels, lipoprotein composition, and fecal steroid excretion in normal yourg adult men. Am J Clin Nutr 1985:42:399-413.

27. Ullich IH, Lai HY, Vona L, Reid RL, Abrink MJ. Alterations of fecal steroid composition induced by changes in dietary fiber consumption. Arn J Chin Nurr 1981;34:2054-60.

28. Macdonald $\mathbb{E A}$. Singh G, Mahony DE, Meier CE. Effect of $\mathrm{pH}$ on bile salt degradacion by mixed fecal culcures. Steroids $1978 ; 32: 221-30$.

29. van Dokkum W, de Boer BC], van Faassen A Pikaar NA, Hermus RJ. Dier, faecal pH and colorectal cancer. Br J Cancer 1983:48:109-10.

30. Cohen BI, Raicht RF, Fazzini E. Reduction of N-muthyl-N-nitrosourea-induced colon tumors in the rat by cholesterol. Cancer Res 1982;42:5050-2.

31. Férezou J. Gouffier E, Coste T. Daily elimination of fecal neutral sterols by humans. Digestion 1978:18:201-12.

32. Jenkins DJA, Hill MJ, Cummings JH. Effect of wheat fiber on blood lipids, fecal steroid excretion and serum iron. Am J Clin Nucr 1975;28:1408-11.

33. Kay PM, Truswell AS. Effect of wheat fiber on gastrointestinal function, plasma lipids and steroid excrerion in man. Br J Nutr 1977;37:227-34.

34. Nair P. Turjman N. Role of bile acids and neutral sterols in familial cancer syndromes of the colon. Dis Collon Rectum 1983;26:629-32.

35. Wilkins TD, Hackman AS. Two patterns of neutral steroid conversion in the feces of normal North Americans. Cancer Res 1974:34:2250 -4.

36. Sian MS, Harding Rains AJ. Bile acid, neurral sterol and faecal fat excretion in subjects treated with fenfluramine and its relationship to fenfuranine-induced diarthea. Postgrad Med I 1979;55:180-7.

37. van der Werf SD], Nagengast FM, van Berge Henegotwen GP, Huijbregts AWM, van Tongeren JHM. Intracolonic environment and the presence of colonic adenomas in man. Gut 1983;24:876-80.

38. Binder $\mathrm{HI}$, Filburn B, Floch M. Bile acid inhibition of intestinal anaerobic organisms. Am J Clin Nutr 1975;28:119-25.

39. Hentges DJ. Does diet infuence human fecal microflora composition? Nutr Rev 1980;38:329-36.

40. IARC Intestinal Micro-ecology group. Dietary fibre, transit-time, faecal bacteria, steroids and colon cancer in rwo Scandinavian populations. Lancet 1977;2:207-1 1 .

41. Reddy BS, Hedges AR, Laakso K, Wynder EL. Metabolic epidemiology of large bowel cancer. Fecal bulk and constituents of high-risk North American and low-riskl Finnish population. Cancer 1978;42:2832-8. 



\section{Chapter 4}

\section{Bile acids and $\mathrm{pH}$ values in total faeces and in faecal water from habitually omnivorous and vegetarian subjects}

Arendina van Faassen, Mathew J. Hazen, Piet A. van den Brandr, Anthony E. van den Bogaard, Rudolph J.J. Hermus and. Ruud A. Janknegt.

Based on: Am. J. Clin. Nutr. 58 (1993) $917-922$

\section{Abstract}

Twenty habitually omnivorous subjects and 19 habitual lacto-ovo-vegetarians aged 59-65 yrs collected faeces during 4 consecutive days. The concentrations of bile acids in total faeces did not differ between the omnivores and vegetarians, but the bile acid concentrations in faecal water were significantly lower in the vegetarians. The concentration of the colorectal cancer-predicting bile acid deoxycholic acid in faecal water was explained by the intake of saturated fat and the daily faecal wet weight $\left(\mathrm{r}^{2}=0.50\right)$. Faecal $\mathrm{pH}$ did not differ between the omnivores and vegetarians. This parameter was significantly $(p<0.05)$ explained by the intake of calcium $\left(r^{2}=0.30\right) ; 24$-h faecal wet weight and defaecation frequency were significantly higher in the vegetarians. In conclusion, our vegetarian subjects had a lower concentration of deoxycholic acid in faecal water, higher faecal wet weight and a higher defaecation frequency than the omnivorous subjects.

\section{Introduction}

Omnivores have a higher colorectal cancer mortality than vegetarians $(1,2)$. In a previous study, we found a lower concentration of deoxycholic acid (DC), one of the main faecal bile acids, in total faeces and a lower $\mathrm{pH}$ of total faeces 
in subjects on a vegan diet compared to those with an omnivorous diet (3). DC may be a promoting factor for colorectal cancer. In epidemiological correlation and some case-control studies (reviewed in 4) and in a prospective study with ulcerative colitis patients an increased concentration of DC in total faeces was associated with a high risk on colorectal cancer (5). The ratio of primary to secondary bile acids was lower in high-risk patient groups (6). The ratio of the orher main faecal bile acid, lithocholic acid (LC), to DC was higher in patients than control subjects (7). In experimental studies on rats (8), a higher concentration of DC resulted in a higher incidence of collorectal tumours.

A high faecal pH has been associated with an increased risk of colorectal cancer in correlation studies between countries (9-11), within countries $(12,13)$, as well as in case-control studies $(14,15)$. However, in a more recent case-control study no difference in gastrointestinal $\mathrm{pH}$ measured by a $\mathrm{pH}$ sensitive radiotelemetry capsule, was found (16). Acidification of stools of rats and enhanced transit time due to dietary supplementation with lactulose or sulphate diminished the number of colon tumours after treatment with dimethylhydrazine (17). On the other hand rats treated with dimethylhydrazine and a low colonic $\mathrm{pH}$ due to consumption of high amounts of guar or pectin showed a higher tumour incidence than controls (18).

More recently higher concentrations of DC in faecal water (19) and plasma (20) have been detected in patients than in control subjects. It has been postulated (21) that the concentration of DC in faecal water might be a better marker for colorectal cancer risk than the concentration in total faeces, because this concentration represents the amount of $D C$ which will be in contact with the colonic mucosa. A high concentration of DC combined with a high $\mathrm{pH}$ showed the most severly damaging effect on a perfused colon (22).

Our previous study was performed under metabolically controlled conditions and only bile acids and pH in total faeces were measured. In the present study we measured bile acids and $\mathrm{pH}$ in total and in the aqueous phase of faeces of habitual omnivores and vegetarians.

\section{Methods}

Recruitment of subjects

Subjects were recruiced in two ways. One hundred forty-nine omnivores were recruited at random from a larger age- (55-69 yrs) and sex-stratified sample 
( $n=594)$, drawn from 23 municipalities in the Nerherlands which participate in a pilot investigation for a cohort study on diet and cancer (23). They were asked to assess faecall $\mathrm{pH}$ using a strip of $\mathrm{pH}$ paper (Combur-3-test; Boehringer, Mannheim, Germany) and send the self assessed samples to the laboratory (24). Additionally, 11 vegetarians were recruited by the Dutch Vegetarian Society to perform the same activities, and then 10 more to send only faecal samples.

The study protocol was approved by the Medical Erhics Committees of the State University Limburg and the TNO-Nutrition and Toxicology Institute.

A structured dietary history interview was taken from the respondents at their homes (25). The frequency and amount (number of standard portions) of food items were asked. Portion sizes of important food items were checked by weighing. To minimize the effects of seasonal variation, the reference period covered the whole year preceding the interview. Nutrient intake was calculated using the standardized Dutch Uniform Encoding System (26) and the 1984 release of the National computerized Dutch Nurrient Databank (27). This databank is prepared by a national committee.

The individuals who volunteered for self-assessment of faecal $\mathrm{pH}$ received at home a styrofoam box with $25 \mathrm{~kg}$ dry ice $\left(-78^{\circ} \mathrm{C}\right)$, a plastic bucket that fit into the toiler (Emergo, Landsmeer, "The Netherlands) and coded plastic bags that fit into the bucket. On 4 consecurive days, the plastic bags containing the stools were transferred to the dry ice to freeze quickly. Defaecarion date and time, and contamination with urine were recorded on a form. After $12.00 \mathrm{~h}$ on the fourth day, the box containing the remaining dry ice, the stool samples and the form were mailed to the laboratory.

\section{Laboratory methods}

The stools were weighed to the nearest gram and stored in a freezer at $-20^{\circ} \mathrm{C}$. The defaecation frequency was calculated from the number of stools between $15.00 \mathrm{~h}$ on the first day and $12.00 \mathrm{~h}$ on the fourth day. Ar the end of the study period of three mo the stools were thawed at $4^{\circ} \mathrm{C}$ to avoid $\mathrm{pH}$ changes and mixed inside the bag by kneading vigorously. The homogeneous-looking mixture was transferred to plastic bowls and mixed again by stirring with a wooden spatula. The $\mathrm{pH}$ was measured with a $\mathrm{pH}$ electrode for small samples at rwo positions and the average $\mathrm{pH}$ was recorded. The $\mathrm{pH}$ meter was calibrated with buffers of $\mathrm{pH} 4$ and 7 . 
Measurement of the $\mathrm{pH}$ of homogenized faeces with an electrode for small samples appeared to be feasible and reproducible, al though a few samples took about 1 minute before the value stabilized. Nevertheless, most samples could be measured immediately. The CV as calculated from 20 duplicate measurements was $2 \%$. Only the first two stools were analyzed because only a fraction of the subjects had three bowel movements during the sampling period.

Samples of 20 omnivores who were randomly selected and samples from all 19 vegetarians were used for the analysis of bile acids. Eight-gram samples of subsequently produced stool samples were combined per subject. This way of pooling results in an averaged concentration of exposure to the colon. Faecal water was isolated by centrifuging the wet faeces for $2 \mathrm{~h}$ at $25,000 \mathrm{xg}$ in the $250 \mathrm{ml}$ bucker of a hook-rotated centrifuge rotor (XL-80;Beckman, Palo Alto, CA). A good separation between faecal water and pellet was achieved in all faecal samples.

Bile acids in total faeces were isolated as earlier (28). The methyl esters of bile acids were silylated with a pyridin/Hydrox-sil (Chrompack, Middelburg, The Netherlands) mixture $(3: 1 \mathrm{vol} / \mathrm{vol})$ for $30 \mathrm{~min}$ at $80^{\circ} \mathrm{C}$. After evaporation of the reagent, the residue was dissolved in hexane and centrifuged for $5 \mathrm{~min}$ at $1000 \mathrm{x}$. The supernate was analyzed on a capillary fused silica column $25 \mathrm{~m}$ length and with $0.32 \mathrm{~mm}$ internal diameter coated with $0.2 \mu \mathrm{m}$ CP Sil $19 \mathrm{CB}$ (Chrompack) combined with a capillary fused silica column $5 \mathrm{~m}$ length and wich $0.25 \mathrm{~mm}$ internal diameter coated with $0.25 \mu \mathrm{m}$ CP Sil 8 CB by using a Dani 8521-a gas chromatograph (DANI SpA, Monza, Milan,Italy) and a splitless, hot-needle injection technique. Operation conditions were as follows: the column oven temperature 6 sec at $200^{\circ} \mathrm{C}, 2.5 \mathrm{~min}$ increasing at $20^{\circ}$ $\mathrm{C} / \mathrm{min}, 10 \mathrm{~min}$ at $250^{\circ} \mathrm{C}, 8 \mathrm{~min}$ increasing at $3^{\circ} \mathrm{C} / \mathrm{min}$ and then $15 \mathrm{~min}$ $275^{\circ} \mathrm{C}$. Temperature of the injector port was $285^{\circ} \mathrm{C}$, the hydrogen flame derector was $300^{\circ} \mathrm{C}$. The head pressure was $0.8 \times 10^{5} \mathrm{~Pa}$ helium. Peaks were identified by comparing their relative retention times with those of pure standards from Sigma (Instruchemie, Hilversum, The Netherlands). The amount of each steroid was calculated from the peak height and detector response relative to the internal standard (hyodeoxycholic acid).

Bile acids from faecal water were isolated by extraction with diethylether after acidifying with diluted $\mathrm{MCl}$. Gas chromatography was performed as described above. The $\mathrm{pH}$ of faecal water was measured at $37^{\circ} \mathrm{C}$ with a glass $\mathrm{pH}$ electrode. 
Differences in dietary intake and faecal values berween omnivores and vegetarians and between males and females were assessed by Student's t-test. Variables with skewed distributions were logarithmically transformed. Linear regression was used to examine determinants of the faecal variables (29).

\section{Results}

Of the omnivores, 17 males and 30 females volunteered to collect stools on four consecutive days about 9 weeks after the dietary survey. The stools of 6 subjects $(11 \%)$ were not used for determination of faecal $\mathrm{pH}$, because they were already thawed on arrival at the laboratory. The stools from 4 subjects $(7 \%)$ were not analyzed for faecal $\mathrm{pH}$, because it was indicated on the accompanying form that the faeces were contaminated with urine. Seven vegetarian males and 14 females collected stools; 11 of them filled in the dietary questionnaire.

Table 1 shows that the habitual vegetarians had significantly $(p<0.05)$ lower intake of saturated fat, monounsarurated fat and animal protein, whereas the intake of polyunsaturated fat, dietary fibre and vegetable protein was significantly higher. The intake of calcium tended to be higher in the vegetarians than in the omnivores $(\mathrm{p}<0.1)$.

The concentrations of bile acids in total faeces did not differ between the omnivorous and vegetarian groups (Table 2). Moreover, the ratio of primary bile acids - chenodeoxycholic acid (CDC) and cholic acid (C) - to their secondary bile acids - LC plus isolithocholic acid (ILC) and DC plus isodeoxycholic acid (IDC) - did not differ berween the two groups. The LC:DC ratio was marginally lower for vegetarians (Table 2).

Table 3 shows that faecal bulk was significantly larger for vegetarians than omnivores $(\mathrm{p}<0.05)$, and defaecation frequency was higher. Moreover, males had a higher defaecation frequency than females in both vegetarians and omnivores $(p<0.05)$. Fourty-two of the volunters collected at least two stools. The mean $\mathrm{pH}$ values of these two stools did not differ significandy between omnivorous and vegetarian groups $(\mathrm{p}>0.05$ ), nor did the $\mathrm{pH}$ of pooled faecal water.

The concentrations of the following bille acids in faecal water were significantly lower for vegetarians than omnivores: $I D C, D C, C D C, C$ and the sum of 
TABLE 1

Nutrient intake of omnwores and wegetarians

\begin{tabular}{|c|c|c|}
\hline Nutrient & $\begin{array}{l}\text { omniwores } \\
(n=20)\end{array}$ & $\begin{array}{l}\text { vegetarians } \\
(n=11)\end{array}$ \\
\hline Energy $(\mathrm{k} / \mathrm{d})^{*}$ & $9229 \pm 2606$ & $9232 \pm 1509$ \\
\hline Far $(g / d)$ & $92.9 \pm 33.9$ & $81.7 \pm 22.7$ \\
\hline Saturated & $42.8 \pm 16.9$ & $30.5 \pm 14.9^{*}$ \\
\hline Monounsacurated & $33.8 \pm 12.6$ & $28.5 \pm 8.2^{\text {f }}$ \\
\hline Polyunsaturated & $14.0 \pm 6.3$ & $19.7+6.7^{4}$ \\
\hline$P: S^{b^{*}}$ & $0.32 \pm 0.13$ & $0.68 \pm 0.90^{*}$ \\
\hline Cholesterol $(g / d)$ & $352 \pm 114$ & $177 \pm 124$ \\
\hline Fiber $(\mathrm{g} / \mathrm{d})^{*}$ & $27.3 \pm 6.5$ & $40.8 \pm 11.0^{3 *}$ \\
\hline From cereal" & $11.4 \pm 4.7$ & $17.8 \pm 5.6^{*}$ \\
\hline From fruit and vegetables & $158 \pm 4.9$ & $23.1 \pm 9.3^{3}$ \\
\hline Protein $(g / d)$ & $76.3 \pm 19.6$ & $642 \pm 18.1$ \\
\hline animal & $51.0 \pm 16.4$ & $28.4 \pm 17.0^{*}$ \\
\hline vegetable & $25.5 \pm 5.7$ & $35.8 \pm 6.5^{*}$ \\
\hline Carbolydrates $(g / d)$ & $242 \pm 56$ & $261 \pm 68$ \\
\hline Mono- and disacharides. & $\$ 19 \pm 45$ & $110 \pm 33$ \\
\hline Polysaccharides & $122 \pm 28$ & $139 \pm 41$ \\
\hline Calcium (mg/d) & $887 \pm 309$ & $1155 \pm 4.80^{5}$ \\
\hline vitamin $C(\mathrm{mg} / \mathrm{d})^{*}$ & $118 \pm 56$ & $134 \pm 76$ \\
\hline
\end{tabular}

Mean \pm SD

Ratio of polyunsaturated to saturated fat

* Logaridumically transformed in t-test

"Significandy different from omaivores $p<0.05$

Marginally different from omnivores, $p<0.1$

the analyzed bile acids (Table 4). In the vegetarians the percentage of ILC+ LC was higher, whereas the percentage of IDC $+D C$ was lower in the aqueous phase of faeces leading to a higher ratio of ILC + LC to IDC * DC for faecal water. The ratio of $\mathrm{DC}$ in the aqueous phase to $\mathrm{DC}$ in total faces was significantly lower for vegetarians than omnivores (mean \pm SD) $0.044 \pm$ 0.024 versus $0.018 \pm 0.016$

To explain these results in terms of dietary intake, regression analyses were performed by using different models. The models that explained most of the variance in the faccal parameters are shown in Table 5. Fifty percent of the variance in the concentration of DC in faecal water could be explained by the intake of saturated fat, faecal bulk and sex. In omnivores the same amount of variance was explained by sex and incake of saturated fat. Thirty-nine percent 
TABLE 2

Concentration of bile acids in total faeces from habitual om mivores $(n=20)$ and wegerarians

Bile acid

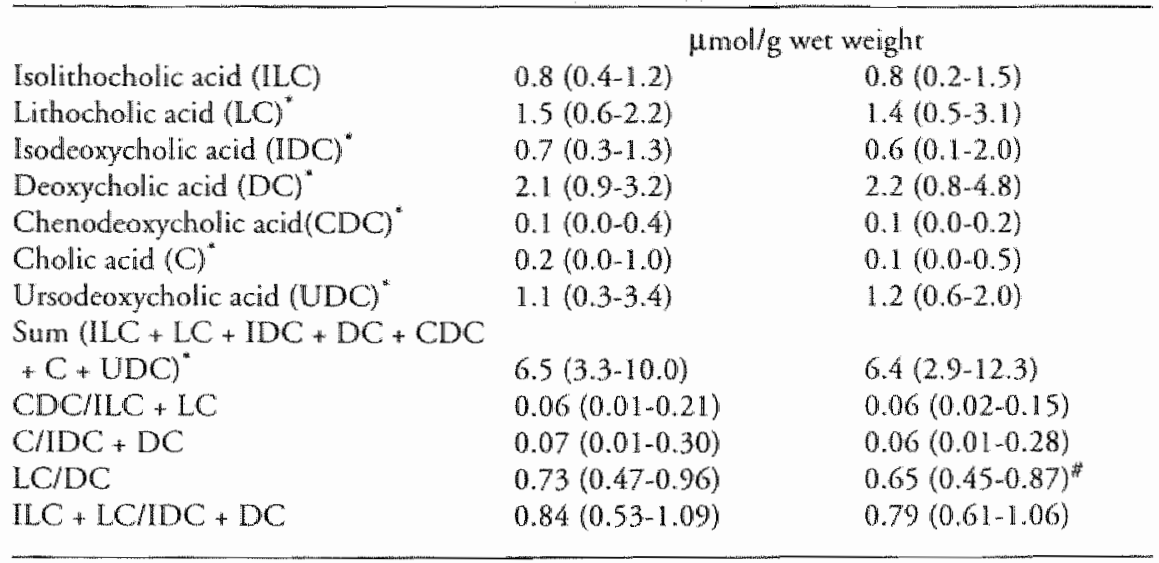

al mean, range in parentheses.

"Logarithmically transformed in t-test

Marginally different from omnivores, $\mathbb{P}<0.1$

\section{TABLE 3}

Faecal variables of habitual omnivores and vegetarians ${ }^{\text {a }}$

\begin{tabular}{|c|c|c|}
\hline Faecal variable & Omniwores & Vegecallians \\
\hline Bulk $(\mathrm{g} / 24 \mathrm{~h})^{*}$ & $119 \pm 61[19 \rrbracket$ & $189 \pm 70[15]^{\#}$ \\
\hline Dry weight (\% by wt) & $27.1 \pm 4.5[20]$ & $27.9 \pm 6.6119\rfloor$ \\
\hline $\begin{array}{l}\text { Faecal water (m/g faeces) } \\
\text { Defaecation frequency }\end{array}$ & $0.33 \pm 0.09[20]$ & $0.34 \pm 0.15[19]$ \\
\hline (number of srools $/ 24 \mathrm{~h}$ )" & $0.9 \pm 0.3[20]$ & $1.5 \pm 0.6[17]^{\#}$ \\
\hline Bile acid excretion fumol/day)" & $505 \pm 150[18]$ & $489 \pm 178 \llbracket 15 \rrbracket$ \\
\hline Mean pH of two srools" & $6.8 \pm 0.3\lceil 23\rceil$ & $6.8 \pm 0.5 \llbracket 17]$ \\
\hline Facal water $p H$ & $6.9 \pm 0.6[20]$ & $7.1 \pm 0.6\lfloor 2 !]$ \\
\hline
\end{tabular}

mean $\pm \mathrm{SD}$; n in brackets

* Logarithmically ransformed in t-tese

Significandly different from omnivores, $\mathrm{p}<0.05$.

of the variance in faecal bulk was explained by the daily amount of cereals, fruits and vegetables and sex. Defaecation frequency was explained significantly by the intake of fibre from fruits and vegetables and by sex.

Unexpectedly, $30 \%$ of the variance in faecal $\mathrm{pH}$ was explained by the intake of calcium. Figure 1 shows the regression line between these two variables. 
TABLE 4

Concentration of bile acids in faccal water from habitual omniwores and vegetarians

Bile acid

$\begin{array}{ll}\text { Omnivores } & \text { Vegetarians } \\ (n=20) & (n=19)\end{array}$

Isolithochalic acid (LC)

unnoll

Lithocholic acid (LC)

$10(2-28)$

$23(7-97)$

$8(0-23)$

Isodeoxycholic acid (IDC) ${ }^{*}$

$27(10-77)$

$21(6-94)$

$87(23-247)$

$15(3-38)^{3 / 4}$

Deoxycholic acid (DC)

$6(0-19)$

$34(4-77)^{4}$

Chenodeoxycholic acid (CDC)"

$19(0-83)$

$2(0-10)^{\prime \prime}$

Cholic acid $(\mathrm{C})$ "

$11(2-23)$

$5(0-22)^{4}$

Ursodeoxycholic acid (UDC)"

Sum (ILC + LC + IDC + DC +

$13(2-48)$

$C D C+C+U D C)$

$187(59-442)$

$98(34-213)^{4}$

$D C+\| D C / S u m$

$0.6(0.4-0.9)$

$0.5(0.2-0.7)^{\#}$

$\mathrm{LC}+1 \mathrm{LC} /$ Sum

$0.2(0.1-0.4)$

$0.3(0.1-0.5)^{\text {th }}$

$(\mathrm{LC}+\mathrm{LC} / \mathrm{DC}+\mathrm{DC})$

$0.4(0.1-1.1)$

$0.8(0.2-2.1)^{\text {年 }}$

"mean; range in parentheses.

"Logarithmically transformed in t-test

* Significantly different from omnivores, $p<0.05$.

TABLE 5

Linear regression of faecal parameters.

\begin{tabular}{|c|c|c|c|c|}
\hline Dependent variable & Explanatory variable & $\beta$ & SE $\mathbb{P}$ & $r^{2}$ \\
\hline${ }^{10} \log \mathrm{DC}$ in fatecal water & $\operatorname{Sex}(1=$ male, $2=$ female $)$ & 0.16 & 0.11 & \\
\hline \multirow[t]{2}{*}{$(\mu \mathrm{mol} / \mathrm{l})$} & ${ }^{10} \mathrm{Log}$ saturared fac $(\mathrm{g} / \mathrm{d})$ & $0.87^{14}$ & 0.24 & \\
\hline & ${ }^{10} \mathrm{Log}$ faecal bulk $(\mathrm{g} / 24 \mathrm{~h})$ & $-0.41^{*}$ & 0.22 & 0.50 \\
\hline \multirow[t]{3}{*}{${ }^{10} \log$ faccal bulk $(\mathrm{g} / 24 \mathrm{~h})$} & Sex $(1=$ male 2 -female $)$ & $-0.16^{i t}$ & 0.08 & \\
\hline & ${ }^{10} \log$ cereal fiber $(g / d)$ & $0.46^{*}$ & 0.22 & \\
\hline & ${ }^{10} \mathrm{Log}$ fruit and vegetable fiber $(\mathrm{g} / \mathrm{d})$ & $0.59^{\circ}$ & 0.23 & 0.39 \\
\hline${ }^{10} \log$ defacation frequency & Sex (1=male, $2=$ female $)$ & $-0.16^{*}$ & 0.07 & \\
\hline \multirow{2}{*}{$(\operatorname{sicools} / 24 h)$} & ${ }^{10} \mathrm{Log}$ ccreal fiber $(\mathrm{g} / \mathrm{d})$ & 0.25 & 0.18 & \\
\hline & ${ }^{10} \mathrm{Log}$ fruit and wegerable fiber $(\mathrm{g} / \mathrm{d})$ & $0.47^{*}$ & 0.19 & 0.35 \\
\hline${ }^{10} \mathrm{Log}$ meat $\mathrm{pH}$ of two srools & Calcium (mg/day) & $5 \times 10^{-5 *}$ & $2 \times 10^{-5}$ & 0.30 \\
\hline
\end{tabular}




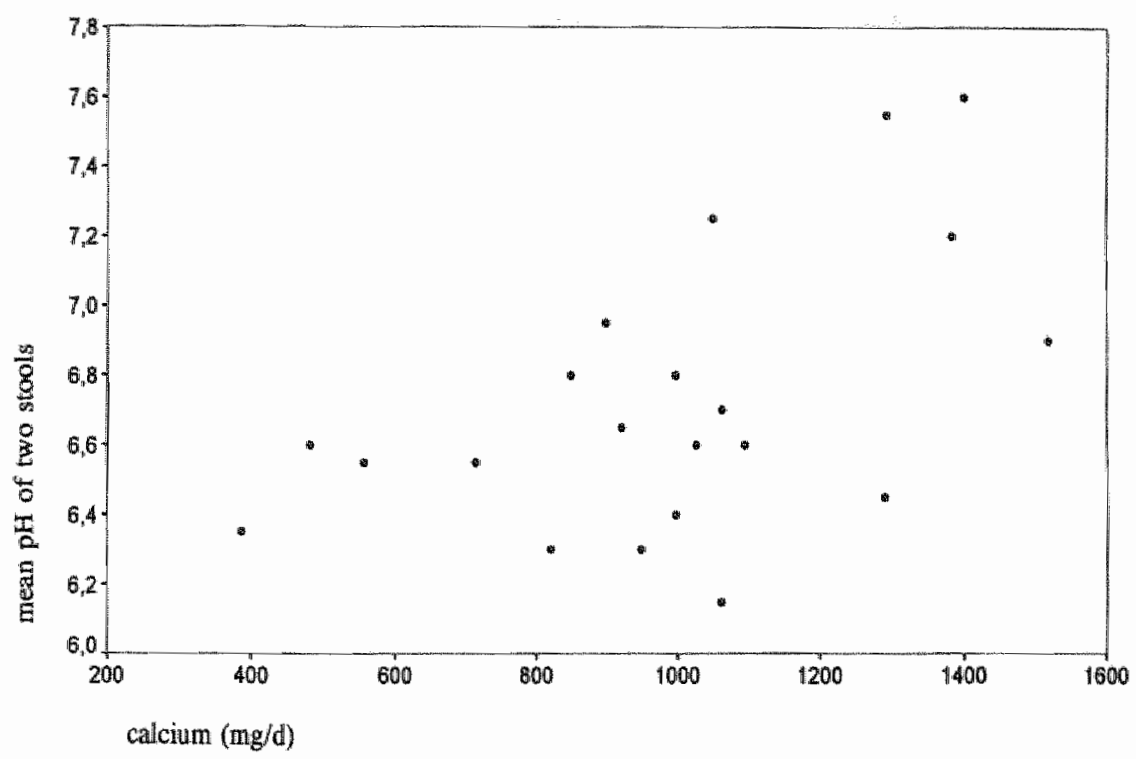

FIGURE 1

mean $p H$ of wo stools $=6.1 \pm 0.0006$ Ca-intake. SE $\beta=0.0003 ; r^{2}=0.24$

\section{Discussion}

The aim of this study was to determine differences between omnivorous and vegetarian groups in faecal variables that have been associated with the risk of developing colorectal cancer, i.e. bile acids (especially deoxycholic acid) and faecal $\mathrm{pH}$.

The volunteers were visited at their homes. Only those who were able to answer the dietary questions and to collect stools in the proper way were entered in to the study.

Intake of nutrients from supplements were not included in the dietary data. Only $3 \%$ of Dutch onminvores of age $50-64$ yrs use vitamin $\mathrm{C}$ pills and only $1 \%$ use calcium supplements (30). Of the vegetarians, $30 \%$ use supplements, calcium among others, and $25 \%$ use vitamin $\mathrm{C}$ supplements (31). Therefore, the differences between omnivores and vegetarians in intake of calcium and vitamin $C$ are probably higher than calculated.

The concentration of DC in total faeces did not differ between omnivores and vegetarians, but the concentration of DC in faecal water was significantly 
lower in the vegetarians. Turjman et al (32) found lower concentrations of DC in the total faeces of vegetarians, but the diets of the males studied contained significantly less fat than those of the omnivores (33). In the present study the vegetarians did not consume signicantly less fat than the omnivores (Table I).

Our results agree with those of others: a lower concentration of DC in faecal water when volunteers changed from a normal diet to a low-fat dier (34) and from a mixed to a lacto-owo-vegetarian diet (35). The lower concentration of $D C$ in faecal water was explained significantly by the intake of saturated fat and faecal bulk. Saturated fat may enhance the concentration of DC in faecal water by delivering saturated fatry acids to the gastrointestinal tract, which displace DC from its unsoluble calcium salt (36). Most probably, the higher faecal bulk in vegetarians caused a lower concentration of DC in the aqueous phase due to binding of DC solid material such as fibre, bacteria, calcium or magnesium ions (37). It also confirms why animal or saturated fat and low fiber have been associated with the risk of colorectal cancer and its precursors, colorectal adenomas (38).

The higher ratios of LC + ILC to DC + IDC in total faeces from the omnivores agree with the higher fatios in patients with colorectal cancer than in control subjects (7). We also found a negative correlation between the ratio LC + ILC to IDC + DC and faecal bulk (39). On the basis of the analytical method used by Owen et al (7), the concentrations of IDC + DC and ILC + LC in our study are comparable with the concentrations of DC and of LC in the study of Owen et al.

Neither the mean $\mathrm{pH}$ values of the two stool samples nor the $\mathrm{pH}$ values of faecal water differed berween the omnivorous and vegetarian groups, although diets differed in contents of dietary fibre. In metabolic studies faecal $\mathrm{pH}$ is lowered in young healthy males by the daily ingestion of large amounts of pectin-rich forms of dietary fibre such as 7 oranges (40), an experimental vegan diet (41) or $35 \mathrm{~g}$ commercial pectin (42). About $18 \mathrm{~g}$ of fibre from oat-bran reduced faecal $\mathrm{pH}$ in older, male and female volunteers (43). Large amounts of other forms of dietary fibre such as corn bran (44) or non-starch polysaccharides from wheat bran $(43,45)$ did not lower faecal $\mathrm{pH}$.

Thornton et al (46) suggested that faecal pH was influenced by the intake of pollymeric carbohydrates. In the regression analyses in the present study faecal $\mathrm{pH}$ was not associated with this dietary variable. Pectin intake would have been higher in the vegetarians, because vitamin $\mathrm{C}$ intake was higher. 
However, a lowering effect of pectin on faecal $\mathrm{pH}$ in the vegetarians would have been counteracted by an enhancing effect of their higher intake of calcium. Our results show a significanc positive correlation between the mean $\mathrm{pH}$ of the two stools and the intake of calcium. This correlation was much lower berween calcium intake and the $\mathrm{pH}$ of pooled faecal water. Pooling samples for the measurement of $\mathrm{pH}$ is probably not the best method, because samples may influence each other. In experimental studies supplemental calcium (about $1200 \mathrm{mg}$ as calcium carbonate) increased the faecal $\mathrm{pH}$ by 0.3 units $(47,48)$. Also, supplementation of rats with calcium phosphate increased faecal $\mathrm{pH}$ (49). This effect may be explained by the neutralizing effect of calcium in the colon on the poorly absorbed short chain fatty acids like lactate and succinate (50). The effect of reducing the calcium intake from 1000 to $500 \mathrm{mg} / \mathrm{day}$ on faecal $\mathrm{pH}$ (and bile acids) is currently being studied in a clinical trial in the Department of Urology of the State University of Limburg.

Other significant differences in faecal parameters related to colorectal cancer risk included the higher faecal bulk in the vegetarians. A higher faecal bulk has been associated with a lower risk of colorectal cancer (51). The variance in this faecal variable could be partly explained by the intake of dierary fiber from cereals. It could not be explained by the intake of polymeric carbohydrates as reported before (52). After adjustment for fiber intake, males still had a larger faecal bulk than females, although the difference was not statistically significant as have been reported previously (45).

The higher defaecation frequency in vegetarian than in omnivorous subjects corresponds wirh findings based on a questionnaire in the United States (53). Defaecation frequency could be explained partly by sex and the intake of dietary fiber from fruits, vegetables and cereals. In metabolic studies, defaecation frequency increased by the consumption of bran, pectin, cereals, fruits and vegetables (54). The higher defaecation frequency in vegetarians may be explained to a great extent by the higher degree of physical activity of most vegetarians (55). The relation between defaccation frequency and colorectal ancer risk is currently being studied in the Dutch prospective study on diet and cancer (23). The accuracy of the question about defaecation frequency in this study is being studied in our clinical trial mentioned above.

The lower defaecation frequency in females than in males in omnivores as well as in vegetarians ( 2.3 versus $3.0 /$ day and 3.8 versus 5.4 respectively) agrees with the longer gastrointestinal transit time of females (42). It also supports the hypothesis (56) that a difference in transit time causes a higher risk of colorectal cancer in females. 
From our results it appears that the lower risk of colorectal cancer in vegetarians cannor be explained by lower concentrations of bile acids in total faces. On the other hand, the lower concentration of DC in the faecal water may contribute to hte explanation of this difference. This amount of the cancer-promoting bile acid will be in contact with the colonic mucosa. The lower concentration of DC in faecal water in vegetarians may the consequence of the stronger binding of fatry acids than DC to calcium and binding of DC to the increased amounts of solid faecal material. Moreover, the shorter time of contact between this promotor and the colonic mucosa due to the higher defaecation frequency may also contribute to the protection against the development of colorectal cancer in vegetarians.

Lacto-ovo-vegetarians had a lower concentration of DC in faecal water, probably because of the lower intake of saturated fat and the larger amount of faeces. The faecal $\mathrm{pH}$ was not lower in the vegetarians, probably because these subjects had a higher intake of calcium.

\section{Acknowledgements}

We thank A. Huldij, H. Brants of the TNO-Toxicology and Nutrition Institute for collection of the dietary interviews and the stool samples; and Dr. R. van der Meer of the Department of Nutrition, Netherlands Institute for Dairy Research (NIZO) for stimulating discussions and critically reviewing the manuscript.

\section{References}

1. Philips RL, Kuzma JW, Bcason WL, Lotz T. Infuence of selection wersus lifestyle on risk of faral cancer and cardiowascular disease among Seventh-Day Adventists. Am I Epidemiol $1980 ; 112: 296-314$.

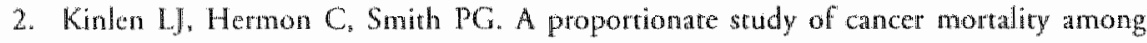
members of a vegetarian socicy. Br ] Cancer 1983;48:355-6\%.

3. Fuasen A van, Bol J, Dokkum W wan, Pikaar NA, Ockhunzen, Th, Harmus RJ]. Bile acids, neutral steroids and bacteria in feces as influenced by a mixed, a lacto-ovovegetarian and a vegan diet. Am J Clin Nut 1987;46:962-7.

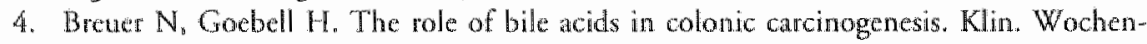
schr. 1985:63:97-105.

5. Hill MJ, Melwille D, Lennard-Jones J, Neale K, Ritchie JK. Faecal bile acids and dysplasia and carcinomis in ulcerariwe colitis. Lancet 1987:2:185-6.

6. McKeigue PM. Adelstein AM, Marmot MG, Henly PI, Owen RW, Hill MJ. Thompson MH. Dier and fecal steroid profile in a South Asian population with a low colon-cancer rare. Am J Clin Nurr 1989:50:151-4. 
7. Owen RW, Dodo M, Thompson MH, Hill MI. The faecal ratio of lithocholic acid to deoxycholic acid may be an improtant aeriological factor in colo-rectal cancer. Biochem.Soc. Trans. 1984:12:86.

8. Hayashi E, Amuro $Y$, Endo $T$. Yamamoto $H$, Myramoto $M$, Kisimoto S. Fecal bile ards and neural sterols in rats with spontaneous colon cancer. Int ] Cancer 1986;37:629-32.

9. Drasar BS, Hill MJ. Bacteria, steroids and cancer of the colon. In: Drasar BS, Mill MJ, eds. Human intescinal flora. London: Academic Press, 1974:212-222.

10. IARC intestinal micro-ecology group. Dietary fbre, transit-tine, faecal bacteria, steroids and colon cancer in wo scandinavian populations. Lancer 1977;2:207-11.

11. Jensen OM, Maclennan R, Wahrendorf ]. Diet, bowrel function, fecal characteristics, and large bowel cancer in Denmark and Finland. Nutr Cancer 1982;4:5-19.

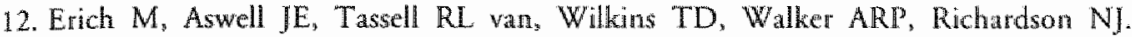
Muragens in the feces of 3 South-African populations at different levels of risk for colon cancer. Mutarion Res 1979:64:231-40.

13. Malhotra SL. Faecal urobilinogen levels and $\mathrm{pH}$ of stools in population groups wich. different incidence of cancer of rhe colon, and their possible role in its aetiology. J Royal Soc Med 1982;75:709-14.

14. Macdonald IA, Webb GR. Mahony D. Fecal hydroxysteroid dehydrogenase activities in vegetarian Seventh-Day Adventists, control subjects, and bowel cancer parients. Am J Clin Nutr 1978;31:\$233-8.

15. Pietroiusri A, Giuliano M, Vita P. Ciamiello P, Caprilli R. Faccal pH and cancer of the lange bowel. Gastroenterology 1983;84:1273.

16. Pye $G$, Evans DF, Ledingham $S$, Hardcastle JD. Gastrointescinal intraluminal pH in normal subjects and those with colorectal adenoma or catcinoma. Gut 1990;31:1355-7.

17. Samuelson SL, Nelson RL, Nyhus LM. Protective role of faecal pH in experimental. carcinogenesis. J Royal Soc Med 1985;78:230-3.

18. Jacobs LR, Lupton JR. Relationship between colonic luminal $\mathrm{pH}$, cell proliferation, and colon carcinogenesis in 1,2-dimethylhydrazine-treated rats fed high fiber diets. Cancer Res 1986;46:1727-34.

19. Stadler J, Yeung, KS, Furrer R, Marcon N, Himal HS, Bruce WR. Proliferative activity of rectal mucasa and soluble fecal bille acids in pattients with normal colons and in parients with colonic polyps or cancer. Cancer Lett 1988;38:315-20.

20. Bayerdorffer $\mathrm{E}$, Mannes $\mathrm{GA}$, Richter WO. Increased secondaty bile acids in the serum of men with colorectal adenomas. Gastroenterology 1991; 100(5) S:A349.

21. Newmark HL, Wargowich MI, Bruce WR. Colon cancer and dietary fat, phosphate, and calcium: a hypothesis. J Nat Cancer Inst 1984:72:1323-5.

22. Rafter JD, Eng VWS, Furrer R, Medine A, Bruce WR. Effects of calcium and pH on the mucosal damage produced by deoxycholic acid in the rat colon. Gur; $1986: 1320-9$.

23. Brandt PA van den, Goldbohm RA, Veer P wan 't, Volovicz A, Hemus RI], Surmans F. A large-scale prospective chohort study on dier and cancer in the Nethentands. $]$ Clin Epidemiol $1990 ; 43: 285-95$

24. Faassen $A$ van, Veer $P$ van ', Bausch-Goldbohm RA, Sturmans F, Hernus RI]. SelE-as. sessmenr of faecal $\mathrm{pH}$ and faecal bulk in epidemiological studies. Br J Cancer $1992 ; 65: 735-6$.

25. Bausch-Goldbohm RA, Brand P van den, Veer van 'c, Sturmans F. Hermus RJ]. Results of the methodological study for the design of a simplified, self-administered questionnaire. In: Riboli E, Saracei R, eds. Dict, hormones and cancer: methodological issues for prospective studies. Lyon, France: LARC, 1988:79-89 (Technical reporr 4). 
26. Hatrast $1 \mathrm{GA}$. Commissie uniforme codering voedingsmiddelen: ontwikkeling van cen system on gegwens wan voedingsenquetes met behulp van de computer te verwerken. Voeding $1975,36,356-60$ (in Dutch).

27. Voolichingsbureat woor de Voeding. NEVO table. Dutch food composition table 1984-1985. The Hague, The Netherlands: Voorlichtingsbureau voor de Voeding, 1984.

28. Faassen A van, Nagengast FM, Hectors M, Brock WJM wan den, Huijbregts AWM, Werf SDJ wan der, Berge Henegouwen GP van, Tongeren JHM van. Deteminarion of individual faccal bile acids by gas-liquid chromarography using dimethoxypropane for simultancous solvolysis and methylation. Clin Chim Acta 1985; $52: 231-9$.

29. Armitage P and Berry G. Statistical methods in medical research. Oxford: Blackwell, 1987.

30. Dorant E, wan den Brandr PA, Hamstra AM, Feenstra HM, Bausch-Goldbohm RA. Dietary supplement use in the Netherlands (Durch). Ned Tijdschr Geneesk 1991;135:68-73 (in Dutch).

31. Bants HAM, Lowik MRH, Westenbrink S, Hushof KFAM, Kisternaker C Adequacy of a vegerarian dier at old age. I Am Coll Nur 1990;9:292-302.

32 Tujman N, Goodman GI, Jaeger B, Nair, P. Dier, nutrition intake and metabolism in populations at high and low risk for colon cancer. Metabolism of bile acids. Am J Clin Nutr 1984:40:937-41.

33. Rider AA, Arthur RS, Callins BM. Diet, nurrition inake, and metabolism in populations at high and low risk for colon cancer. Laboratory analysis of 3-day composite of food samples. Am J Clin Nurr 1984;40:914-6.

34. Sradler J, Stem HS, Yeung KAS, Mcguire V, Furrer R, Marcon N, Bruce WR. Effect of high far consumption on cell proliferation activity of colorecral mucosa and on soluble faecal bile acids. Gut 1986;29:1326-31.

35. Allinger UG, Johansson GK, Fafter JJ. Shife from a mixed to a lactovegetarian diet: influence on acidic lipids in fecal water - a potental risk factor for colon cancer. Am J Clin Nur 1989;50:992-6.

36. Bhatchcharyya $A K$, Thera $C$, Anderson JT, Grande F, Keys A. Diecary calcium and fac. Effect on serum lipids and fecal excretion of cholesterol and its degradation products in man. Am J Clin Nutr 1969,22:1161-74.

37. Newmark HL, Wargovich MI. Bruce WR. Colon cancer and dietary fat, phosphate, and calcium: a hypothesis. J Nat Cancer Inst 1984;72:1323-5.

38. Giovannucci $E$, Stampfer MJ, Coldiz $G$, Rimm EB, Willet WC. Retationship of dier to risk of colorectal adenoma in men. I Natl Cancer Insr 1992;84:91-8.

39. Brydon WG, Eastwood MA, Elton RA. The relationshp beween stool weight and the Lichocholatefdeoxycholate ratio in Gaces. Br I Cancer 1988;57:635-6.

40. Walker ARP, Walker BF, Segal I. Faecal pH value and ies modificarion by dietary means in Souch Afriwa black and white schoolchilden. S Afr Med ) 191979,55:495-8.

41. Dokkun W war, Boer BCJ de, Faassen A wan, Pikar NA, Hermus RJ. Diet, faecal pH and colorecal cancer. Br" Jance 1983,48:109-10.

42. Heming SE, Marthinsen $\mathrm{D}$, Kuhnlew $H$. Colonic funcrion and fermentation in men consuming high fiber diews, N Nuer 1983:1 13:2435-544.

43. Kashan H. Stern HS. Jenkins DJA, Jenkins AL. Thompson LU. Hay K, Marcon $\mathbb{N}$. Minkin $S$. Bruce WR. Colonic fermencation and markers of colorectal-cancer risk. Am I Clin Nuter 1992;55:723-8.

44. Neming $S E$, O'Donnell $A U$, Perman JA. Influence of frequent and long-term bean consumption on colonic function and fermentation. Am J Clin Nutr 1985:41:909-18. 
45. Stephen AM, Wiggins HS, Englyst HN, Cole TJ, Wayman BJ, Cummings JH. The effect of age, sex and level of intake of dietary fibre from wheat on large-bowel function in thirty healthy subjects. Brit ] Nutr 1986:56:349-61.

46. Thornton ]R, Dryden A, Kelleher J. Losowsky M.S. Super-efficient starch absopt:ton. A risk factor for colonic neoplasia? Dig Dis Sci 1987,32:1088*91.

47. Gregoire RC, Stern HS, Yeung KS, Stadler J, Langley S, Furrer R. Bruce Wh. Effect of calcium supplementation on mucosal cell proliferation in high risk patients for colon cancer. Gut 1989;30:376-82.

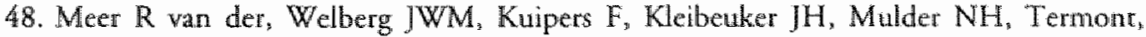
DSML, Vonk RJ, Vries, HT de, Vries EGE de. Effect of supplemental dietary calcium on the intestinal association of calcium, phosphate, and bile acids. Gastroenterology $1990 ; 99: 1653-9$.

49. Lapré JA, Vries DSM de, Kleibeuker JH, Vries ECE. Mechanism of the protective effect of supplemental dietary calcum on cytolytic acrivity of fecal water. Cancer Res $1993 ; 53: 1-6$.

50. Newmark HL, Lupton JR. Determinants and consequences of colonic luminal pH: implications for colonic cancer. Nutr Cancer 1990;14:161-73.

51. Glober GA, Kamiyama 5, Nomura A, Shimada A, Abba BC. Bowel transit-times and. srool weight in populacions with different colon-cancer risks. Lancet 1977;2:110-1.

52. Shetry PS, Kurpad AV. Increasing starch intake in the thuman dier increases fecal bulking. Arr. J Clin Nutr 1986;43:210-2.

53. Freeland-Graves JH, Greninger $S A$, Graves GR, Young RK. Health practices, artirudes, and beliefs of vegetarians and nonvegetarians. Am J Diet Assoc 1986;86:913-8.

54. Stasse-Wolthuis $M$. Influence of dietary fibre on cholesterol metabolism and colonic function in healthy subjecrs. Wrld Rev Nutr Diet 1981;36:100w40.

55. Holdstock DJ, Misiewica J], Smith T, Rowlands EN. Propulsion (mass movements) in the human colon and its relationship to meals and somatic acrivity. Gut 1979;1 1:91-9.

56. McMichael AJ, Potter JD. Do intrinsic sex differences in lower alimentary tract physiology infuence the sex-specific risks of bowel cancer and other biliary and intestinal diseases? Am J Epidemiol 1983;118:620-7. 



\section{Chapter 5}

\section{Effects of a calcium binder on solubility of bile acids and fatty acids in the large intestine of the rat}

Arendina van Faassen, Anthony E. van den Bogaard, Matthew J. Hazen and Ruud $A$. Janknegt

Based on: Cancer Lett. 81 (1994) 77-80

\section{Abstract}

Kidney stone patients with hypercalciuria type I are treated with an oral calcium binder. Lower intakes of calcium $(\mathrm{Ca})$ in the range of $0-1500$ $\mathrm{mg} /$ day have been associated with an increased incidence of colorectal cancer. The aim of this study is to analyze the effects of feeding ethylene diamine tetracetic acid sodium salt (EDTA), a strong, non-absorbable binder of $\mathrm{Ca}$, on the solubility of bile acids (BA) and long chain fatty acids (LCFA) in the large intestine of the rat. We have shown that the concentrations of soluble BA and LCFA in the large intestine contents remained constant while the concentration of total BA and LCFA decreased. Therefore, lowering the amount of Ca available for binding BA or LCFA is unlikely to increase the risk of colorectal cancer by that method.

\section{Introduction}

We are treating kidney stone patients with hypercalciuria type I with an oral calcium binder (1). Lower intakes of calcium (Ca) in the range of $0-1500$ $\mathrm{mg} / \mathrm{day}$ have been associated with a higher risls of colonic cancer in epidemiological studies (2-5). Higher intakes of Ca ( $1000-3000 \mathrm{mg} / \mathrm{day})$ have been associated with a reduced incidence of colorectal cancer in experimental studies in humans $(6,7)$ and animals (8). The protective effect of Ca has been explained by the precipitation of bile acids (BA) and long chain 
farty acids (LCFA) in the large intestine, by that decreasing the contact of these toxic compounds with epithelial colon cells (9). Another mechanism may be the direct stimulation of epithelial cell differentation (10).

We studied the effect of calcium binding by feeding rats ethylene diamine tetracetic acid sodium salt (NA 2 EDTA), a strong, non-absorbable binder of $\mathrm{Ca}$. The aim of the study was to analyze the effects of lower availability of colonic $\mathrm{Ca}$ on the solubility of BA and LCFA in the large intestine of the rat.

\section{Materials and methods}

Animals and their treatment

Twenty male SPF BN/M rats, 12 weeks old and weighing approximately 250 g, were obtained from the Centralized Experimental Animal Facilities of the University of Limburg and divided at random into 4 groups of 5 animals. The animals were housed under standardized conditions; each group in a separated macrolon cage with sterilized woodshavings as bedding marerial. They were fed ad libitum with a commercially available rat chow (SRM-A, Hope farms, Woerden, The Netherlands) containing approximately $1.4 \% \mathrm{Ca}$ and $0.2 \%$ magnesium and had free access to demineralized drinking water, acidified with $\mathrm{HCl}$ to approximately $\mathrm{pH} 3$.

At day 0 all animals received subcutaneously $0.5 \mathrm{ml}$ of a ferri-dextrane solution (Prevan-200, AUV, Cuyck, the Netherlands) containing $200 \mathrm{mg}$ $\mathrm{Fe}^{3+}$ per $\mathrm{ml}$ to prevent iron deficiency. For group 2 this was repeated after 7 days and for group 3 the injection was repeated after 7 and after 14 days. Three groups were given twice daily at approximately 8.00 and $16.00 \mathrm{~h} 2 \mathrm{ml}$ of water containing $10 \%(w / v)$ EDTA by gavage. The fourth group served as a control group and was given twice daily $2 \mathrm{ml}$ of water by gavage. After 7 days the control group (group 0) and group 1 was euthanized with a $\mathrm{CO}_{2} / \mathrm{O}_{2}$ mixture (11), a blood sample taken by aorta-puncture in tubes containing EDTA for hemoglobin measurement. In the morning the contents of caecum and colon were collected for measurement of soluble and total BA, LCFA and $\mathrm{Ca}$. After two weeks group 2 and after three weeks group 3 was treated in the same way. 
Faecal water is difficult to separate from faeces of rats. We therefore analyzed soluble BA and LCFA from caecal contents. Due to limited amounts of caecal water per rat, the caecal contents of each group were pooled. Total BA and LCFA were analyzed in the colonic contents of each rat.

The concentrations of soluble BA and LCFA were analyzed in the supernatants of the pooled caeca of 5 rats of a group after centrifuging during $2 \mathrm{~h}$ at $25,000 \times \mathrm{g}$. The concentrations of total BA and total LCFA were analyzed in the contents of the colon of individual rats after freeze-drying.

The analysis of bille acids was performed as described before (12) using 7-ketodeoxycholic acid instead of hyodeoxycholic acid as internal standard. Briefly, total bile acids were isolated after hydrolysis in $76 \%(\mathrm{w} / \mathrm{v})$ methanolic solution containing $1 \mathrm{~N} \mathrm{NaOH}$. After extraction of neutral steroids and fatry acids with petroleum ether and acidifying the mixture to $\mathrm{pH}<1$ with concentrated $\mathrm{HCl}$, bile acids were extracted with diethyl ether. They were then methylated in methanol/2,2 dimethoxypropane/concentrated $\mathrm{HCl}$ and silylated with pyridin/Hydrox-sil mixture (Chrompack, Middelburg, The Netherlands). The derivatives were analyzed on a combination of a capillary fused silica column coated with CP Sil 19 CB and one coated with CP Sil 5 CB. Soluble bile acids were isolated with the same method starting hydrolysis of faecal water in $100 \%$ methanol containing $1.25 \mathrm{M} \mathrm{NaOH}$.

The concentrations of unesterified LCFA were measured as following: freeze dried contents of the colon were spiked with an internal standard (heptadecanoic acid) and incubated during $1 \mathrm{~h}$ at roomtemperature with methanol containing $1 \mathrm{mM} \mathrm{HCl}$. After stopping the teaction with water, the LCFA were extracted with hexane. The derivatives were analysed on a $50 \mathrm{mx}$ $0.25 \mathrm{~mm}$ i.d. capillary glass column coated with $0.2 \mathrm{um}$ CP Sil88 (Chrompack, Middelburg, The Netherlands) using a Dani 8521 -a gaschromatograph (DANI S.p.A., Monza, Milan, Italy). Operation conditions were as follows: column oven temperature rising at $4^{\circ} \mathrm{C} / \mathrm{min}$ from $160^{\circ} \mathrm{C}$ to $230^{\circ} \mathrm{C}$ injector port remperature $230^{\circ} \mathrm{C}$; hydrogen flame detecror $250^{\circ} \mathrm{C}$; head pressure 1.6 Bar He; split-flow $50 \mathrm{ml} / \mathrm{min}$. Faecal waters were dried in a vacuum-concentrator (Heto, Instrumentenhandel, The Hague, The Netherlands). After methylation and extraction with hexane, the derivatives were analyzed by a splitless, hot-needle injection technique. Operation conditions were: column oven temperature $2 \mathrm{~min}$ at $80^{\circ} \mathrm{C}$, rising at $30^{\circ} \mathrm{C} / \mathrm{min}$ from $80^{\circ} \mathrm{C}$ to $160^{\circ} \mathrm{C}$ and at $4^{\circ} \mathrm{C} / \mathrm{min}$ from $160^{\circ} \mathrm{C}$ to $230^{\circ} \mathrm{C}$; injector port temperature $230^{\circ} \mathrm{C}$; hydrogen flame detector $250^{\circ} \mathrm{C}$; head pressure $2.5 \mathrm{Bar} \mathrm{He}$. With this method the variability of LCFA in total faeces was lower than $5 \%$. The variability of 
the analysis of soluble LCFA was lower than 10\% for the main LCFA (C16:0, C18:0, C18:1 and C18:2) making about 90\% of the total LCFA in rats, while the variability of the analysis of the other LCFA was approximately $20 \%$. Only main LCFA ar analyzed, therefore.

The concentrations of calcium in colonic contents were analyzed by atomic absorption spectrophotometry after destruction of freeze dried material by 3 $h$ boiling in $20 \% \mathrm{H}_{2} \mathrm{O}_{2}$ and $1 \mathrm{~N} \mathrm{HCl}$ at the Laboratory of Clinical Chemistry of the University Hospital Maastricht.

Differences between groups are analyzed using Student's t-test.

\section{Results}

The animals stayed healthy during the study as observed by the technicians giving them daily the EDTA-solution by gavage. The concentration of hemoglobin in blood remained constant.

The concentrations of $\mathrm{BA}$ in the supernatant of centrifuged caecal contents remained constant during the experiment, although the concentration of total BA in the colon content decreased considerably (Table 1).

The concentrations of LCFA in the supernatant of centrifuged caecal contents of groups 1 to 3 were much lower than those of the controls (group 0). The concentration of total LCFA in the colonic contents was significantly lower for groups 2 and 3 when compared with group 0 (Table 2).

\section{TABLE $\mathbb{1}$.}

Concentracions of soluble bile acids in pooled caecal contents and of toral bile acids in colonic contents of rats fed EDTA

\begin{tabular}{lll}
\hline Group no. & $\begin{array}{l}\text { Soluble bile acids } \\
\text { in poolled caecal } \\
\text { contents }(\mu \mathrm{mol} / \mathrm{l})\end{array}$ & $\begin{array}{l}\text { Total bille acids } \\
\text { in colonic contents } \\
(\mu \mathrm{mol} / \mathrm{g} \text { wet weight } \pm S D)\end{array}$ \\
\hline 0 & 76 & $1.3 \pm 0.5$ \\
1 & 70 & $0.9 \pm 0.3$ \\
2 & 99 & $0.6 \pm 0.1^{*}$ \\
3 & 75 & $0.4 \pm 0.1^{*}$ \\
\hline
\end{tabular}

\footnotetext{
Significantly different from group $0(p<0.05)$
} 
TABLE 2

Concentrations of soluble long chain farty acids in pooled caccal contents and of total long chain fatty acids in collonic contents of rats fed EDTA

\begin{tabular}{lcl}
\hline Group no. & $\begin{array}{l}\text { Soluble long chain fatry acids } \\
(\mu \mathrm{mol} /)\end{array}$ & $\begin{array}{l}\text { Total long chain fatry acids } \\
(\mu \mathrm{mol} / \mathrm{g} \text { wet weight } \pm \mathrm{SD})\end{array}$ \\
\hline 0 & $244^{*}$ & $16.8 \pm 3.3$ \\
1 & $29^{*}$ & $14.0 \pm 3.7$ \\
2 & $56^{*}$ & $11.5 \pm 4.1^{*}$ \\
3 & $21^{*}$ & $10.8 \pm 2.7^{*}$
\end{tabular}

Significantly different from group $0(\mathrm{p}<0.05)$

TABLE 3

Concentrations of calcium in and weights of colonic contents of rats fed EDTA

\begin{tabular}{llll}
\hline Group no. & $\begin{array}{l}\text { Calcium } \\
(\mathrm{mmol} / \mathrm{g} \pm \mathrm{SD})\end{array}$ & $\begin{array}{l}\text { Weight } \\
(\mathrm{g} \pm \mathrm{SD})\end{array}$ & $\begin{array}{l}\text { "Excretion" } \\
(\mathrm{mmol} / \mathrm{aninnal} \pm \mathrm{SD})\end{array}$ \\
\hline 0 & $0.185 \pm 0.025$ & $1.10 \pm 0.40$ & $0.21 \pm 0.09$ \\
3 & $0.120 \pm 0.031$ & $2.28 \pm 0.44$ & $0.26 \pm 0.06$ \\
\hline
\end{tabular}

The concentration of $\mathrm{Ca}$ in the colonic contents was lower for group 3 than for group 0 , but multiplying the concentration with the weight of the colonic contents showed a higher 'excretion' of calcium by group 3 than by group 0 (Table 3).

\section{Discussion}

EDTA is a very efficient binder of cations with two free protons like calcium, magnesium, etc. We therefore fed rats with EDTA to study the effect of free calcium-binding on solubility of BA and LCFA in the gastrointestinal tract. A high solubility of these compounds is associated with an increased risk of developing colorectal cancer.

The pattern of faecal bile acids in our rats is slightly different from humans; that of fecal LCFA is similar (results not shown).

Assuming a consumption of $15 \mathrm{~g}$ chow per day, the molar proportion of EDTA to Ca intake would be $1: 5$. However only $30 \%$ of the $\mathrm{Ca}$ in the chow 
is avallable as free calcium (results not shown and personal communication of Hope Farms). Therefore the ratio between the intake of EDTA and Ca was about 1:2.

Because rats normally eat during wilight hours and EDTA-gavage was at 8.00 and $16.00 \mathrm{~h}$, the intake of EDTA and Ca was about the same time.

The total concentration of BA in the colon contents decreased after EDTAfeding. Most likely this is caused by a lower excretion of $\mathrm{BA}$ in the colon, because multiplying the total concentration in wer weight with the weights of the colonic contents showed a significantly lower 'excretion' by group 4 than group 0. This lower excretion will be due to less precipitated BA by calcium and magnesium, which were bound by EDTA. The amount of soluble BA remained constant despire the decreasing amount of $\mathrm{BA}$.

The total concentration of LCFA decreased after EDTA-feeding, although the products of concentration and weights of colonic contents showed no significantly lower 'excretion' of LCFA due to EDTA-treatment. This will be due to the stronger binding of Ca to LCFA than to EDTA (9). The amount of soluble LCFA decreased strongly after feeding EDTA. This cannot be explained by a lower $\mathrm{pH}$ due to lower calcium availability (13), because the $\mathrm{pH}$ of caccal water increased from 5.7 in group 0 to 6.5 in group 3 (results not shown). It may be explained by pulling $C a$ which is bound to EDTA in the stomach, into the intestine. After the production of free LCFA in the small intestine by splitting dietary triglycerides, the higher amount of $\mathrm{Ca}$ is bound to the LCFA, resulring in lower concentrations of soluble LCFA in groups 1. -3 .

This study shows that lowering the amount of $\mathrm{Ca}$ available for binding $\mathrm{BA}$ or LCFA is unlikely to increase the risk of colorectal cancer by that method, because ir docs not increase the concentrations of soluble BA or LCFA in the large intestine and it lowers the concentration of total faecal BA and LCFA. Whether this effect also occurs in humans consuming between 0 and $1500 \mathrm{mg}$ Ca per day, has to been shown in our clinical trial with kidney stones patients, who are prescribed a calcium-poor dier $(500 \mathrm{mg} / \mathrm{d}) \mathrm{due}$ to their hypercalciuria type II.

\section{References}

1. Churchill, D.N. (1987) Medical reament to prevent recurrent calcium urolithiasis. Mineral Electrolyce Metab., 13, 294-304. 
2. Garland, C., Barrer-Connor, E., Rossof, A.H., Shekelle, R.B., Criqui, M.H. and PAUL. O. (1985) Dietary vitamin $\mathrm{D}$ and calcim and risk of colorectal cancer: 1 19-year prospective study in men. Lancer, $1,307-309$.

3. Slattery, M.L., Sorenson, A.W. Ford, M.H. (1988) Dietary calcium intake as at mirigating factor in colon cancer. Am. J. Epidemiol. 128, 504-514.

4. Stemmerman, G.N., Nomura, A., Chyou, P.H. (1990) The influence of dairy and nondairy calcium on subsite large bowel-cancer fisk. Dis. Colon Rectum, 33, 190-194.

5. Peters, R.K., Pike, M.C., Garabrant, D. and Mack, T.M. (1992) Diet and colon cancer in Los Angeles County, California. Cancer Causes Control, 3, 457-473

6. Rozen, P., Fireman, Z., Fine, N., Wax, Y., Ron, E. (1989) Oral calcium supresses increased rectal epirhelial proliferation of persons at risk of colorectal cancer. Gut, 30 , 650-655.

7. Wargovich, M.J., Isbell, G., Shabot, M., Winn, R., Lanza, F., Hochman, L., Larson, E. Lynch, P., Roubein, L. and Levin, B. (1992) Calcium supplementation decreases rectal epithelial cell proliferation in subjects wich sporadic adenoma. Gastroenterollogy, 103 , 92-97.

8. Wargovich, M.J., Baer, A.R. (1989) Basic and dinical investigations of dietary calcium in the prevention of colorectal cancer. Prev. Med. 18,672-679.

9. Newmark, H.L., Wargovich, M.J., Bruce, W.R. (1984) Colon cancer and dietary fat, phosphate, and calcium: a hypothesis. J. Narl. Cancer Inst. 72, 1323-1325.

10. Newmark, H.L. and Lipkin, M. (1992) Calcium, witamin D, and colon cancer. Cancer Res., 52, 20675-20705.

11. Bogaard, A. E. van den, Dam, E. van and Weekers, F.H. (1985) Use of carbon dioxide as euthanising agent of rats. Biotechniek, 2, 22-24 (in dutch)

12. Kok T.M.C.M. de, Levels, P.J., Fassen, A. van, Hoor, E. ten, Kleinjans, J.C.S. (1992) Chromatographic methods for the denermination of toxicants in facts. J. Chromatography, $580,135-159$.

13. Faassen, A. van, Hazen, M.J., Brandt, P.A. van den, Bogaard, A.E. van den, Hermus, R.J.I. and Janknegr, R.A. (1993) Bile acids and $\mathrm{pH}$ values in rotal feces and in focal warer from habicually ommivorous and vegetarian subjects. Am. J. Clin. Nutr. 58,917-922. 



\section{Chapter 6}

\section{Effects of Calcisorb ${ }^{\circledast}$ on faecal bile acids and fatty acids in human volunteers}

Arendina van Faassen, Anthony E. van den Bogaard, Marthew J. Hazen, Phil Geerlings, Rudolph J.J. Hermus and Ruud A. Janknegt

\section{Submitted}

\section{Abstract}

The intake of calcium ( $\mathrm{Ca}$ ) is negatively associated with colorectal cancer (CRC) risk. The aim of this study was to investigate in a double blind, placebo controlled trial, the effects of the Ca-binder Calcisomb ${ }^{\circledR}$, which is given to kidney stone patients with hypercalciuria type I, on risk factors for CRC risk, bile acids (BA) and long chain fatry acids (LCFA) in faecal water. Results show that the concentration of BA and LCFA in faecal warer did not change, although the urinary excretion of $\mathrm{Ca}$ and magnesium and the concentration of $C a$ and magnesium in faecal water decreased. The daily excretion of $B A$ and LCFA acids decreased significantly $(\mathrm{p}<0.05)$ during the Calcisorb ${ }^{\mathbb{B}}$-period. In conclusion binding dietary $\mathrm{Ca}$ and magnesium with Calcisorb ${ }^{(B)}$ from a diet with a relatively low amount of fat does not enhance the solubility of BA and LCFA in faecal water.

\section{Introduction}

Lower intakes of callium (Ca) are associated with an increased risk of colorecral cancer (CRC) in some epidemiological studies (1-4), but recently no significant association (5) and no significant association after adjustment for vitamin $D$ intake (6) were found. In experimental studies in humans $(7,8)$ and amimals (9) Ca-supplementation decreases rectal epithelial cell proliferation. 
The protective effect of $\mathrm{Ca}$ has been explained by the precipitation of bile acids (BA) and long chain fatry acids (LCFA), decreasing the contact of these toxic compounds with epithelial colorectal cells [10]. Another mechanism may be the direct stimulation of epithelial cell differentation by $\mathrm{Ca}$ (11).

Untill now, the potential modulating effect of $\mathrm{Ca}$ has been studied by supplementing the diet with $\mathrm{Ca}$ from pharmaceutical preparations $(12,13)$ or by omitting the calcium from milk (14).

The aim of this study is to investigate the effects of Calcisorb ${ }^{\circledR}$ on the solubility of BA and LCFA in the faeces as markers for colorectal cancer risk. Calcisorb is used in the therapy of kidney stones with hypercalciuria type I (15). This product contains sodium cellulosephosphate and binds cations like calcium (Ca) and magnesium (Mg). It is not absorbed from the intestinal tract and hydrolysis in the large intestine is minimal (information from the supplier). While the incidence of hypercalciuria type I is low, the placebo-controlled trial was performed with healthy volunteers.

\section{Materials and methods}

\section{Subjects}

Two adult male subjects $(A B, M H)$ participated in a pilot study. For the placebo-controlled trial six healthy male volunteers were recruited from the staff of the University of Limburg. They were $23(2 \mathrm{x}), 45(2 x)$ and 46 yrs old. They were all without medication which might influence $\mathrm{Ca}$, bile acid and/or fatty acid metabolism. All subjects gave their informed consent, and all of them finished the study.

\section{Experimental protocol}

The study protocol of the trial was approved by the Medical Ethics Committee of the University Hospital Maastricht.

In the pilot study the subjects consumed $15 \mathrm{~g}$ Calcisorb ${ }^{\circledR}$ (Riker/3M, Zoeterwoude, The Netherlands) per day for three weeks. Faeces were sampled for one day before the trial, weekly during the Calcisorb ${ }^{\circledR}$ intake and one week after stopping the supplementation. 
Before starting the trial, the six volunteers recorded their diet during three days (Thursday, Friday and Saturday) in specially designed diaries. They were asked to maintain their usual dietary habits during those days and during the trial. The major moments of $\mathrm{Ca}$ intake were analyzed by a dietician. At those moments the subjects were asked to take their prescribed dose of Calcisorb ${ }^{(B)}$ or placebo (see below) during one week. At the end of the second period the volunteers again recorded their diet during three days (Sunday, Monday and Tuesday).

A double-blind cross-over design was used to eliminate bias due to subjects' or investigators' attitudes. To control for carry-over effects there was one week interval between both treatment periods. Subjects were divided at random between the group which started with the Calcisorb ${ }^{(B)}$ and the one which started with the placebo.

Before starting the experiment and at the end of both experimental periods, the volunteers sampled urine for $2 \times 24$ hours during weekdays and all stools for $2 \times 24$ hours during the weekend. During 7 days before sampling stools the subjects took 10 radiopaque cubic pellets (Resprecare Medical B.V, Den Haag, The Netherlands; specific gravity $1.36 \mathrm{mg} / \mathrm{mm}^{3}$ ) three times a day for correcting excretion values for faecal flow.

All faecal and urinary samples were coded so that the origin of the samples was unknown during processing and chemical analysis.

\section{Experimental products}

The Calcisorb ${ }^{\circledR}$ was supplied following the prescription of the supplier: $15 \mathrm{~g}$ per day. This amount showed to have rigourous effects on faccal bile acids and fatty acids in the pilot study. It contains $3 \mathrm{mmol}$ phosphate per gram (information from Riker and results of our analysis). The placebo (also $15 \mathrm{~g}$ per day) was made by the Dept. of Clinical Pharmacy, Academic Hospital Maastricht and consisted of microcrystalline, depolymerized cellulose (Avicel. PH 101) coloured with a small amount of ferric oxide. This placebo had the same texture, colour and taste as Calcisorb ${ }^{\circledR}$ and did not swell in water. Both products were easy to consume after mixing e.g. in coffee or apple mash. 
The dietary records were coded by a dietitian using the Dutch Uniform Encoding System (16). Nutrient intake was calculated using the 1990 release of the National Computerized Dutch Nutrient Databank (17). Stability of the diet during the two experimental periods was checked by measurement of

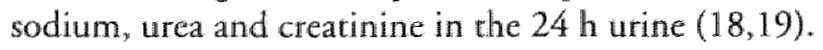

\section{Urinary collection and analyses}

Urine was sampled during $2 \times 24 \mathrm{~h}$ using a small sampler $(8 \mathrm{~cm}$ diameter $\times 15$ $\mathrm{cm}$ heught) (U-mate P, Sumitomo Bakelite Co, Tokyo, Japan) with the lower part filled with $1.7 \mathrm{~g}$ boric acid as preservative. It is based on the principle of the sampler described by Tochikubo (20). The apparatus is double-bottomed and has a pipe-shaped scale with a stopcock leading to the lower compartment. The diameter of the pipe is $1 / 50$ of that of the upper compartment. The urine is voided into the main compartment. A constant fraction, can be sampled from the pipe and stored in the subcompartment. The remainder of the urine in the main compartment can be discarded. By repeating this manipulation 1/50 of the total urine excreted during 24 hours can be collected in the small cup. With this small apparatus, $24 \mathrm{~h}$ urine can be sampled very easily and without having to carry a big jerrycan of 2,51 . The sampler can be cleaned and desinfected by soap and hypochlorite.

Utinary analyses were performed by the Dept. of Clinical Chemistry of the Academic Hospital Maastricht. Creatinin was measured by a colorimetric assay of the Dimension ${ }^{(2)}$ clinical chemistry system (Dupont de Nemours, Wilmington, U.S.A.) and urea by the method of the Dimension system. Sodium was analyzed by flame spectroscopy on a photometer (model 943, Instrumentation Labotatory Incorporation, Milan,Italy). Ca and $\mathrm{Mg}$ were determined by aromic absorption spectrophotometry (model AA/AE 551, Instrumentation Laboratory Incorporation, Milan,Italy.) with long path air acetylene burner (IL 43005-02) Phosphate was determined as described by the Dimension ${ }^{\circledR}{ }$ system.

\section{Stool collection and analyses}

Stools were collected in coded plastic bags which were folded in a plastic bucker which fits into the toilet (Emergo, Landsmeer, The Netherlands). The stools were placed immediately after defaecation between four frozen ele- 
ments of a freezing pack that were surrounded by styrofoam plates in a cardboard box. In this manner sampling materials and faecal samples can be easily mailed and the samples stay below $5^{\circ} \mathrm{C}$ during four days. Faccal pH was stable at this temperature.

In the laboratory the stools were weighed, flattened for $x$-raying and stored in a freezer at $-20^{\circ} \mathrm{C}$. X-rays were made using AGFA-Gevaert Curix RPI films of $24 \times 30 \mathrm{~cm}$ in Kodak X-omatic cassettes in a Philips camera type Practix. The samples (4 per plate) were illuminated at $60 \mathrm{~cm}$ distance by $50 \mathrm{kV}$ for 0.2 sec. The pellets were counted on a lighted bank.

After thawing the samples overnight at $4^{\circ} \mathrm{C}$, they were mixed inside the bag by kneading vigorously. Faecal water was obtained by centrifugation of $24 \mathrm{~g}$ of stools for $2 \mathrm{~h}$ at $25,000 \times \mathrm{g}$ at $20^{\circ} \mathrm{C}$ in the $250 \mathrm{ml}$ bucket of a hook-rotated centrifuge rotor (XL-80; Beckman, Palo Alto, CA). In this way a good separation between faecal water and pellet could be achieved in all samples. Faecal water was carefully aspirated and the $\mathrm{pH}$ was measured at room temperature. Samples were stored at $-20^{\circ} \mathrm{C}$ for further analyses. A part of the homogenized faeces was freeze-dried, and the percentage dry weight calculated.

The analysis of BA was performed as described before (21). The concentrations of unesterified LCFA were measured by a the method described before (22). Briefly, freeze dried faeces $(100 \mathrm{mg})$ and faecal waters $(100 \mu \mathrm{l})$ were spiked with $100 \mu$ l of an internal standard (heptadecanoic acid), dissolved in $0.5 \mathrm{ml}$ methanol and $50 \mu \mathrm{l}$ concentrated $\mathrm{HCl}$ and incubated during $1 \mathrm{~h}$ at room temperature. After stopping the methylation reaction with $0.5 \mathrm{ml}$ water, the LCFA were extracted with $2 \times 1 \mathrm{ml}$ hexane. The derivatives were analyzed by gas-liquid chromatography as described before. The variability of the analysis of the main LCFA (C16:0, C18:0, C18:1 and C18:2) in total faeces and in faecal water was lower than $20 \%$, while the variability of the analysis of the orher LCFA was higher. Only main LCFA were analyzed, therefore. No saponification of myristate cholesterylester occurred during the procedure and only little saponification of $\alpha$-lecithin $(7-16)$.

After ashing of the freeze-dried faeces and digestion in 50 perchloric acid and 7.5 hydrogen peroxide, $\mathrm{Ca}, \mathrm{Mg}$ and phosphate were measured as described above. The concentrations in faecal water were analyzed as described by Van der Meer (10). 


\section{Statistics}

Results are given as mean $\pm S D$. Each value is the mean of measurements of rwo consecutive days. Differences between means at the end of both experimental periods were tested by the Student's $t$-test for paired samples.

\section{Results}

In the pilor study the concentrations of BA and LCFA in faecal water did not change after taking Calcisorb ${ }^{B}$. The concentration in total faeces however, decreased by 50 after one week and returned to the initial values one week after stopping the supplementation. Based on these strong effects in both subjects after one week, we decided to perform the trial during one week with 6 subjects and to apply a one week washout period.

The diet of the volunteers in the trial reflected a typical omnivorous Dutch diet (23) (Table 1). One subject had diarrea a few days before sampling of the faeces during his Calcisor $b^{\circledR}$-period. Moreover, this was the only person with a higher excretion of $\mathrm{Ca}$ in urine during his $\mathrm{Calcisorb}^{\left({ }^{2}\right.}$-period than during the placebo-period. During the Calcisorb ${ }^{\circledR}$-period, he probably consumed much more dietary protein than during the placebo-period, because also his excretion of urea, phosphorous and creatinine was much higher during this period. Therefore the data of this subject are treated separately from the data of the other five subjects.

Urinary markers of dietary intake (Table 2) showed that the intake of sodium and protein did not differ significantly between the periods.

Table 3 shows the total urinary plus faecal excretion of $\mathrm{Ca}, \mathrm{Mg}$ and phosphorous during the placebo and the Calcisorb ${ }^{B}$ - period. The Ca-excretion did not differ between both periods, but the $\mathrm{Mg}$-excretion was lower in the Calcisorb ${ }^{\circledR}$-period. It occured in each subject. As expected, the phosphorousexcretion was much higher in the Calcisorb ${ }^{\circledR}$-period.

The excretion of $\mathrm{Ca}$ and $\mathrm{Mg}$ with urine decreased significantly (Table 4 , The mean decrease of Ca was $1.5 \mathrm{mmol} / \mathrm{d}$, that of $\mathrm{Mg} 2.5 \mathrm{mmol} / \mathrm{d}$ The excretion of phosphorous increased with $7 \mathrm{mmol} / \mathrm{d}$.

The effects of Calcisorb on general faecal variables are shown in Table 5. Faecal bulk was significantly $(\mathrm{p}<0.05)$ lower in the Calcisorb ${ }^{\circledR}$-period. The effects on characteristics of faecal water are collected in Table 6. The $\mathrm{pH}$ of faecal water did not differ significantly. The amount of faecal water was 
TABLE I

Dietary intake of the volunters before the experiment

\begin{tabular}{ll}
\hline & mean \pm SD $(\mathrm{n}=6)$ \\
\hline Energy $($ kcal/d) & $2390 \pm 695$ \\
Total protein $(\mathrm{g} / \mathrm{d})$ & $77.7 \pm 16.4$ \\
Animal protein $(\mathrm{g} / \mathrm{d})$ & $44.8 \pm 14.3$ \\
Total fat $(\mathrm{g} / \mathrm{d})$ & $85.7 \pm 24.4$ \\
Sarurated fat $(\mathrm{g} / \mathrm{d})$ & $33.8 \pm 12.7$ \\
Mono-unsaturated fat $(\mathrm{g} / \mathrm{d})$ & $33.2 \pm 13.1$ \\
Poly-unsacurated far $(\mathrm{g} / \mathrm{d})$ & $14.6 \pm 2.9$ \\
Fibre $(\mathrm{g} / \mathrm{d})$ & $26.9 \pm 7.9$ \\
Calcium $(\mathrm{mg} / \mathrm{d})$ & $1005 \pm 4.9$ \\
Phosphorous $(\mathrm{mg} / \mathrm{d})$ & $1591 \pm 517$ \\
\hline
\end{tabular}

\section{TABLE 2}

Urinary markers of dietary intake during the placebo and the Calcisorb period (mean $\pm S D)$ ( $n=5$; values of omitted subject berween brackers)

\begin{tabular}{llll} 
& placebo & Calcisorb & difference \\
\hline sodium (mmol/d) & $134 \pm 25$ & $158 \pm 49$ & $24,3 \pm 32$ \\
urea (mmol/d) & {$[117]$} & {$[113]$} & \\
& $340 \pm 113$ & $307 \pm 57$ & $33 \pm 117$ \\
creatinine (mmol/d) & {$[342]$} & {$[546]$} & \\
& $19 \pm 4$ & $16 \pm 5$ & $3 \pm 4$ \\
& {$[23]$} & {$[30]$} & \\
\hline
\end{tabular}

\section{TABLE 3}

Total urinary plus fecal excretion of calcium, magnesium and phosphorous during the placeboand the Calciscrb period (mean $\pm S D$ )

( $n=5$; values of omitted subject berween brackets)

\begin{tabular}{|c|c|c|c|}
\hline & placebo & Calcisonb & difference \\
\hline calcium $(\mathrm{mmol} / \mathrm{d})$ & $\begin{array}{l}30.5 \pm 5.5 \\
{[31.11}\end{array}$ & $\begin{array}{l}26.7 \pm 5.4 \\
|62.6|\end{array}$ & $3.8 \pm 5.8$ \\
\hline magnesium (mmol/d) & $\begin{array}{l}21.1 \pm 3.5 \\
{[22.4]}\end{array}$ & $\begin{array}{l}16.9 \pm 2.8 \\
{[49.1]}\end{array}$ & $4.2 \pm 2.1^{\prime \prime}$ \\
\hline phosphare (mmol/d) & $\begin{array}{l}61.6 \pm 5.7 \\
{[67.3]}\end{array}$ & $\begin{array}{l}97.1 \pm 8.6 \\
{[130.9]}\end{array}$ & $35.5 \pm 5.6$ \\
\hline
\end{tabular}

$p<0.05$

Calcisorb and faecal markers of volunteers 79 
THBLE 4

Effects of Calcisonb on uninary excretion of calcium, magnesium and phosphorous (mean \pm SD) ( $n=5$; values of omited subjece berween brackets)

\begin{tabular}{llll}
\hline & placebo & Calcisont & difference \\
\hline alcium (mmol/d) & $3.6 \pm 1.4$ & $2.1 \pm 1.3$ & $1.5 \pm 0.8^{*}$ \\
& {$[6.4]$} & {$[9.5]$} & \\
magnesium (mmol/d) & $5.0 \pm 1.3$ & $2.5 \pm 1.2$ & $2.5 \pm 0.74$ \\
& {$[7.2]$} & {$[5.2]$} & \\
phosphorous (mmol/d) & $31.4 \pm 8.5$ & $38.0 \pm 7.7$ & $6.6 \pm 8.9$ \\
& {$[42.0]$} & {$[69.0]$} & \\
\hline
\end{tabular}

$p<0.05$

* $p<0.01$

TABLE 5

Effects of Calcisonb on general faecal valiables (mean \pm SD)

$(\mathrm{n}=5$; values of omited subject berween brackers)

\begin{tabular}{llll}
\hline & placebo & Calcisorb & difference \\
\hline Defaecation frequency (stools/d) & $1.2 \pm 0.5$ & $1.1 \pm 0.2$ & $0.1 \pm 0.2$ \\
& {$[2]$} & {$[2]$} & \\
Faecal bulk (g wet weigt/d) & $259 \pm 60$ & $204 \pm 62$ & $55 \pm 37^{*}$ \\
& {$[188]$} & {$[302]$} & \\
Dry weight (\%) & $30.0 \pm 5.1$ & $27.7 \pm 3.6$ & $2.3 \pm 5.6$ \\
& {$[33.0]$} & {$[24.2]$} & \\
Faecal water (ml/24g) & $7.4 \pm 1.6$ & $5.4 \pm 1.9$ & $2.0 \pm 1.3^{*}$ \\
& {$[8.6]$} & {$[5.3]$} & \\
\hline
\end{tabular}

" $\mathrm{p}<0.05$

significanty lower $(p<0.01)$ after taking Calcisorb ${ }^{(0)}$. The concentrations of Cand $\mathrm{Mg}$ were lower after consuming Calcisorb ${ }^{\mathbb{B}}$, those of phosphorous higher. The amount of solubilized $C$ a (calculated as the amount of Ca in the aqueous part of the faeces divided by the amount in total faeces) was significantly lower in the Calcisotb ${ }^{(B)}$ period. Concentrations of BA and/or LCFA in faecal water did not change significantly due to the intake of Calcisorb ${ }^{(B)}$ (see also Figure 1 and 2). Faecal excretion of BA and LCFA decreased significanty (Table 7). Faccal excretion of phosphorous increased strongly in the Calcisorb ${ }^{B}$-period. 
TABLE 6

Effects of Calcisorb on constiruents of faecal water (mean \pm 90 )

$(n=5$. values of omirned subject between brackets)

\begin{tabular}{|c|c|c|c|}
\hline & placebo & Calcisont ${ }^{3}$ & difference \\
\hline$p^{H}$ & $\begin{array}{l}6.6 \pm 0.2 \\
{[6.2]}\end{array}$ & $\begin{array}{l}6.4 \pm 0.2 \\
{[5.9]}\end{array}$ & $0.2 \pm 0.3$ \\
\hline Bile acids ( $\mu \mathrm{mol} / \mathrm{l})$ & $\begin{array}{l}130 \pm 44 \\
{[200]}\end{array}$ & $\begin{array}{l}306 \pm 309 \\
{[150]}\end{array}$ & $176 \pm 317$ \\
\hline Long chain farry acids (mmol/1) & $\begin{array}{l}1.4 \pm 1.8 \\
{[3.2]}\end{array}$ & $\begin{array}{l}1.0 \pm 0.5 \\
{[1.3]}\end{array}$ & $0.4 \pm 1.3$ \\
\hline Calcium (mM) & $\begin{array}{l}10.2 \pm 6.1 \\
{[14.8]}\end{array}$ & $\begin{array}{l}5.5 \pm 2.9 \\
{[26.8]}\end{array}$ & $4.7 \pm 5.6$ \\
\hline Magnesium (mM) & $\begin{array}{l}20.2 \pm 5.9 \\
{[40.2]}\end{array}$ & $\begin{array}{l}7.6 \pm 2.1 \\
{[28.7]}\end{array}$ & $12.6 . \pm 5.5^{5}$ \\
\hline Inorganic phosphate (mM) & $\begin{array}{l}19.7 \pm 10.7 \\
{[39.5]}\end{array}$ & $\begin{array}{l}39.8 \pm 9.3 \\
{[15.3]}\end{array}$ & $20.1 \pm 12.9^{*}$ \\
\hline $\begin{array}{l}\text { Rario } \mathrm{Ca} \text { in water to } \mathrm{Ca} \text { in } \\
\text { tolal faeces ( } \mu \mathrm{mol} / \mu \mathrm{mol} \text { ) }\end{array}$ & $\begin{array}{l}0.03 \pm 0.01 \\
{[0.04]}\end{array}$ & $\begin{array}{l}0.01 \pm 0.01 \\
{[0.03\rceil}\end{array}$ & $0.02 \pm 0.01^{\circ}$ \\
\hline
\end{tabular}

$p<0.05$

$\mathrm{p}<0.01$

TABLE 7

Effects of Calcisorb ${ }^{(1)}$ on faecal excretion values (mean \pm SD) ( $n=5$; values of omitted subject between brackets)

\begin{tabular}{|c|c|c|c|}
\hline & placebo & Calcisoub & difference \\
\hline Bile acids $(\mathrm{mmol} / \mathrm{d})$ & $\begin{array}{l}1.1 \pm 0.3 \\
{[0.6]}\end{array}$ & $\begin{array}{l}0.7 \pm 0.1 \\
{[1.5]}\end{array}$ & $0.4 \pm 0.3^{*}$ \\
\hline Long chain farry acids (mmol/d) & $\begin{array}{l}9.4 \pm 2.5 \\
{[10.0]}\end{array}$ & $\begin{array}{l}4.1 \pm 1.5 \\
\lfloor 15.7\rceil\end{array}$ & $5.3 \pm 2.4^{\text {it }}$ \\
\hline Calcium (mmol/d) & $\begin{array}{l}27.0 \pm 5.0 \\
{[24.7]}\end{array}$ & $\begin{array}{l}24.6 \pm 4.6 \\
\llbracket 53.1 \rrbracket\end{array}$ & $2.4 \pm 6.1$ \\
\hline Magnesium (mmol/d) & $\begin{array}{l}16.2 \pm 3.1 \\
{[15.3]}\end{array}$ & $\begin{array}{l}14.4 \pm 2.2 \\
\llbracket 44.0\rfloor\end{array}$ & $1.7 \pm 1.9$ \\
\hline Phosphorous (mol/d) & $\begin{array}{l}30.2 \pm 6.4 \\
{[25.3]}\end{array}$ & $\begin{array}{l}59.1 \pm 3.9 \\
{[61.6]}\end{array}$ & $28.9 \pm 6.2^{\prime \prime}$ \\
\hline
\end{tabular}

$p<0.05$
$p<0.01$ 


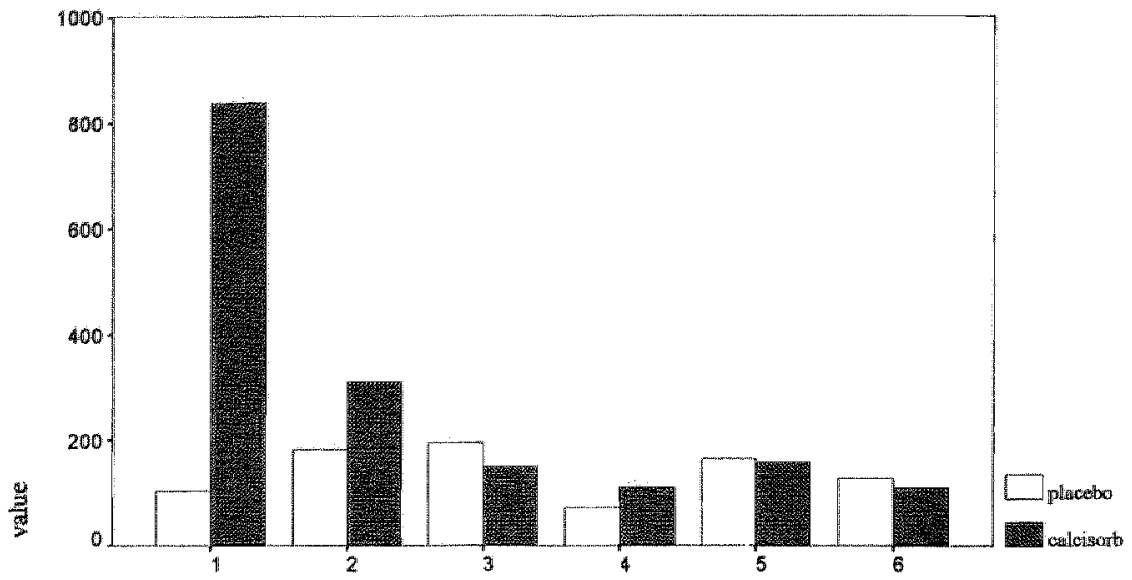

case number

FIGURE 1

Individual values of bile acids in Gaecal water ( $\mu$ mol/1)

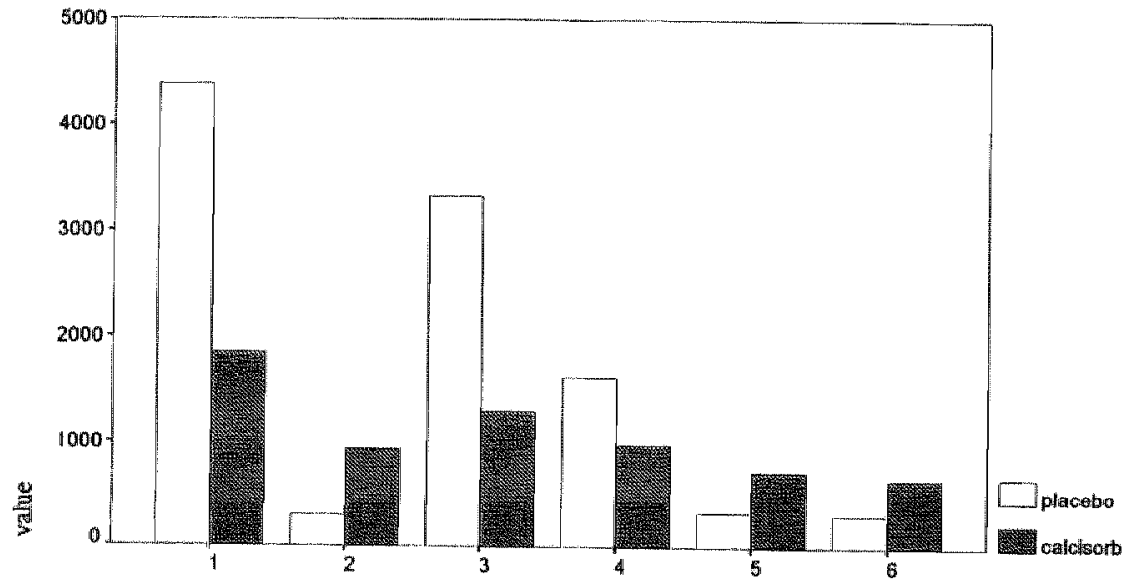

case number

FIGURE 2

Individual values of long chain farty acids in faecal water ( $\mu$ mol/I) 


\section{Discussion}

Intake of $15 \mathrm{~g}$ Calcisorb ${ }^{(B)}$ or placebo per day did not cause discomfort. although gastrointestinal discomfort has been described for Calcisorb $^{(B)}$ in some persons (15). Compared to values before the trial, faecal excretion and faecal water increased a little during the placebo-period (see below). The difference between daily excretion of phosphorous in the Calcisorb ${ }^{3}$. and placebo-period (35 mmol/d) can be explained by the daily intake of $15 \mathrm{~g}$ Calcisorb ${ }^{\circledR}$ which contains $3 \mathrm{mmol}$ phosphorous per gram.

The lower excretion of $\mathrm{Ca}$ and $\mathrm{Mg}$ with urine in the Calcisorb that the absorption of $\mathrm{Ca}$ and $\mathrm{Mg}$ is diminished by the $\mathrm{Calcisorb}^{(B)}$. The higher excretion of phosphorous will have been caused by the hydrolysis of some Calcisorb ${ }^{\circledR}$ in the gastrointestinal tract (information from the supplier).

The faecal wet weight and faecal water in the Callisorb ${ }^{(B)}$-period were equal to the ones before the trial. Therefore the placebo will have increased the faecal weight and the amount of faecal water a little. Although the placebo consisted of microcrystaline, depolymerized cellulose that does not swell (results not shown), most probably the cellulose will have bound a certain amount of water.

The lower amount of $\mathrm{Ca}$ and $\mathrm{Mg}$ in faecal water after the $\mathrm{Calcisorb}{ }^{\circledR}$ intake shows that the binding of $\mathrm{Ca}$ and $\mathrm{Mg}$ to the Calcisorb ${ }^{(B)}$ is still present in the faeces. The higher phosphate concentration in faecal water will be caused by the small hydrolysis of Calcisorb ${ }^{\circledR}$. A lower concentration of Ca in faecal. water may cause a higher risk of colorectal cancer (11).

We did not detect a diminishing effect of Ca-binding on faecal $\mathrm{pH}$ as expected from our previous cross-sectional study with different intakes of $\mathrm{Ca}$ (21) and the dietary study with milk low in Ca by Govers et al (14). This may be due to the range of $\mathrm{Ca}$-intake in this study. $\mathrm{A}$ difference in urinary excretion of $1.5 \mathrm{mmol} / \mathrm{d}$ multiplied by an absorption of abour 30 gives 4.5 $\mathrm{mmol}=180 \mathrm{mg} / \mathrm{d}$. Therefore the range of intake was berween 1000 and 800 $\mathrm{mg} / \mathrm{d}$. In the study of Govers the intake of Ca varied berween 1800 and 800 $\mathrm{mg} / \mathrm{d}$. The scatter diagram of faecal $\mathrm{pH}$ and Ca-intake from our cross-sectional study (21) shows no relation between both variables below a Ca-intake of about $1000 \mathrm{mg} / \mathrm{d}$.

The excretion of $\mathrm{Ca}$ and $\mathrm{Mg}$ with the faeces is not enhanced during the Calcisorb ${ }^{\circledR}$-period. It is difficult to detect the small difference in $\mathrm{Ca}$ and $\mathrm{Mg}$ absorption (1.5 and $2.5 \mathrm{mmol} / \mathrm{d}$ respectively) among the large amount of faecal $\mathrm{Ca}$ and $\mathrm{Mg}$ (27 and $16 \mathrm{mmol} / \mathrm{d}$ respecrively). 
The "Ca-and Mg-binding" by Calcisorb ${ }^{\text {(2) }}$ did not enhance the concentrations of BA or LCFA in faecal water as expected from the hypothesis of Newmark et al (24). In one subject (see Figure 1) the concentration of BA was enhanced extremely in the Calcisorb ${ }^{(}$-period. These high concentrations have been found before (12). We could nor explain this high concentration by faecal or dietary factors.

The daily excretion of BA and LCFA decreased significantly after taking Calcicorb ${ }^{R}$. This corresponds well withan increased excretion of BA and LCFA after supplementation with Ca (10).

The diets in this study contained less far than the amount for which Newmark proposed his hypothesis ( 85 compared to $150 \mathrm{~g} / \mathrm{d}$ ). A high far diet will cause a high concentration of BA and LCFA in faeces. A low Ca-diet may then have a more pronounced effect on BA and LCFA in faecal water than a low fat diet. Such an effect has been reported for rats (25).

In conclusion, binding dietary $\mathrm{Ca}$ and $\mathrm{Mg}$ in the intestinal tract with Calcisorb ${ }^{\circledR}$ from a diet with a relatively low amount of fat apparently does not enhance the solubility of BA and LCFA in faecal water. Kidney stone patients who use this diet and drug, most likely will have no enhanced risk of developing colorectal cancer by this way. The importance of a low concentration of $\mathrm{Ca}$ in faecal water as a risk factor for colorectal cancer has to be studied in animal and epidemiological studies.

\section{Acknowledgements}

We wish to thank mrs. M. van der Westerlaken, M.Sc. of the Dept. of Clinical Pharmacy, Academic Hospital Maastricht for preparing and resting the placebo and randomizing the volunteers. Mr. Walenkamp of Riker/3M, Zoeterwoude provided us with the Calcisorb ${ }^{\circledR}$ and its specifications. Mr. L. Donselaar of the Dept. of Clinical Chemistry, Academic Hospital Maastricht coordinated the clinical chemistry of urine and faecal samples and mr. M. Bost of the Centralized Animal Services made the X-rays of the stools. Dr. R. van der Meer of the Dept. of Nutriton, Netherlands Institute for Dairy Research (NIZO), Ede has critically rewiewed the manuscript. The volunteers are grarefully acknowledged for their dedication. 


\section{References}

1. Garland, C., Barrer-Connor, E., Rossof, A.H., Shekelle, R.B., Criqui, M.H., Paul, O. Dietary vitamin $\mathrm{D}$ and calcium and risk of colorectal cancer: 119 -year prospective study in men. Lancet 1 (1985) 307-309

2. Slartery, M.L., Sorenson, A.W., Ford, M.H. Dietary calcium intake ats a mitigating factor in colon cancer. Am. J. Epidemiol. $128(1988) 504-514$

3. Stemmerman. G.N., Nomura, A., Chyou, P.H. The influence of dairy and nondairy calcum on subsite large bowel cancer risk. Dis. Colon Recum 33 (1990) 190-194

4. Perers, R.K. Pike, M.C., Garabrant, D., Mack, T.M. Diet and colon cancer in Los Angeles Councy, California. Cancer Causes Conrrol 3 (1992) 457.473

5. Kampman, E., Goldbohm, R.A., van den Brandt, P.A. van 'r Veer, P. Fermented dairy products, calcium, and colorecral cancer in the Netherlands Cohort Study. Cancer Res. $54(1994) 3186-3190$

6. Bostick, R.M., Porter, J.D., Sellers, T.A., McKenzie, D.R., Kushi, L.H., Folsom, A.R. Relarion of calcium, vitamin $\mathrm{D}$, and dairy food incake to incidence of colon cancer among older women. The Towa Women's Healch Study. Am.J.Epidemiol. (137) 1302-1317

7. Rozen, P. Fireman, Z., Fine, N., Wax, Y., Ron, E. Oral calcium supresses increased rectal epithelial proliferacion of persons at risk of colorectal cancer. Gut 30 (1989)650-655

8. Wargovich, M.J., Isbell, G., Shabot, M., Winn, R., Lanza, F., Hochman, la, Larsoin, E., Lynch, P., Roubein, L and Levin, B. Calcium supplementation decreases rectal epithelial cell proliferation in subjects with sporadic adenoma. Gastroenterology 103 (11.992) 92-97

9. Wargowich, M.J., Baer, A.R. Basic and clinical investigations of dietary alcium in the prevention of colorectal cancer. Prev. Med. 18(1989) 672-679

10. Meer, R. van der, Welberg, J.W.M., Kuipers, F., Kleibeuker, J.H., Mulder, N.H., Termont, D.S.M.L., Vonk, R.J., de Vries, H.T., de Vries, E.G.E. Effecr of supplemental dietary calcium on the intestinal association of calcium, phosphate, and bile acids. Gastroenterology 99 (1990) $1653-1659$

11. Newmark, H.L. and Lipkin, M. Calcium, vitamin D, and colon cancer. Cancer Res. 52 (1992) $2067 \mathrm{~S}-2070 \mathrm{~S}$

12. Gregoire, R.C., Stern, H.S., Yeung, K.S., Stadler, J, Langley, S., Furrer, R., and Bruce, W.R. Effect of calcium supplementation on mucosal cell proliferacion in high risk patients for colon cancer. Gut 30 (1989) 376-382

13. Lapre, J.A., de Vries, H.T., Termont, D.S.M.L., Kleibeuker, J.H., de Vries, E.G.E der Merer, R. Mechanism of the protective effect of supplenental dietary calcium on Cytolyric activity of fecal water. Cancer Res. 53 (1993) 248-253

14. Gowers, M., Lapre, J., Kleibeuker, J. Vonk, R. and wan de Meer, R. Coalcium in milk products precipiates intestinal surfactants and inhibits luminal cycolyric activity in healny subjects. Gastroenterology 106 (1994): A388

15. Churchill, D.N. Medical treatmene to prevent recurrent calcium urolithảasis. Mincral Electrollyte Metab. 13 (1987) 294-304

16. Hautrast J.G.A.J. Commitee on a uniforn code of foods: development of a system to handle dietary questionatues by computer (Commissie uniforme codering voedingsmiddcten: ontwikkeling van een systcem orm gegevens van vocd ingsenquetes mer behulp wan de computer te verwerken). Voeding 36 (1975) 356-360 (in Durch)

17. Voorlichringsbureau voor de Voeding. NEVO rablc. Durch food composition rable 1990-1991. The Hague, The Nerherlands: Voorlichungsburcau voot de Voeding, 1990

18. Hunter, D. Biochemical indicators of dietary intake. In: W. Willet (ed.), Nutritonal epidemiology, New York, Oxford Unikersicy Press, 1990, p 143-216 
19. Riboli, E, Ronnholm, H., Saracci, R. Biological markers of dier. Cancer Surveys 6 (1987) $685-718$

20. Tochitubo, 0 , Uneda, 5 , and Kaneko, Y. Simple portable device for sampling a whole days urine and ies applicarion to hypertenswe oupatients. Hypertension 5 (1983) $270-274$

21. van Fassen, A. Hazen, M.J, van den Brande, P.A, wan den Bogaard, A.E. Hermus, R.I.J. and Janknegt, RA. Bile acids and $\mathrm{pH}$ values in total feces and in fecal water from habitually omniworous and vegerarian subjects. Am. J. Clin. Nurr. 58 (1993) $917-922$

22. van Faassen, A., wan den Bogaard, A.E., Haxen, M.J. Janknegt, R.A. Effecrs of a calcium binder on the solubility of bile acids and fatry acids in the large intestine of the rar. Cancer Lett. $81(1994) 77-80$

23. Hulshof, K.F.A.M., Kistemaker, C., Bouman, M. The intake of nutrients and food groups by Dutch population groups. TNO report V93.412, Zeist, The Necherlands, 1992 (in Durch)

24. Newmark, H.L., Wargovich, M.J., Bruce, W.R. Colon cancer and dievary far, phosphate, and calcium: a hypothesis. J. Natl. Cancer Inst. 72 (1984) 1323-1325

25. Pence, B.C., Buddingh, F. Inhibition of diecary fat-promoced colon carcinogenesis in rats by supplemental calcium or vitumin $\mathrm{D}_{3}$. Carcinogenesis 9 (1988) $187-190$ 


\section{Chapter 7}

\section{The calcium-restricted diet of urolithiasis patients with hypercalciuria type II: a benefit for kidney stones but a risk for colorectal cancer?}

A. van Faassen, E.M.C. van der Ploeg, M. J. Hazen, A.E. van den Bogaard, H.M.L. Habets, R. van der Meer, R.J.J. Hermus and R.A. Janknegt.

\section{Subwitted}

\section{Abstract}

The calcium (Ca)-restricted diet of urolithiasis patients with hypercalciuria type II may decrease the urinary Ca-excrecion but increase biochemical markers of risk for colorectal cancer (CRC). We allocated twenty-nine patients from 6 hospitals at random into an experimental (Ca-restriction to $500 \mathrm{mg} /$ day) and a control (no restrictions) group for one month. During the trial the experimental group consumed $800 \mathrm{mg}$ less Ca than the control group, but also less animal protein, mono- en disaccharides, polysaccharides, cholesterol, saturated fatty acids, energy, phosphorous and sodium. The urinary Ca-excretion did not decrease significantly, but the oxalate excretion decreased, although not significantly either. The concentration of bile acids and long chain fatty acids in faccal water and its cytotoxicity decreased. We conclude that our Ca-restricted diet, which turned out to be lower in $\mathrm{Ca}$, animal protein and fat due to the omission of dairy products, may be a benefit for male hypercalciuria rype II patients without enhancing theit risk for CRC. For women, a diet restricted in animal protein and table salt may be more effective against urolithiasis, safer for their bones and of equal protection against CRC. 


\section{Introduction}

Urolithiasis patients diagnosed as hypercalciuria type II are those patients that respond to a calcium- $(\mathrm{Ca})$ and sodium-deprived diet during the metabolic screening of recurrent stone formers (1). They have an increased intestinal absorption of $\mathrm{Ca}$ (35 compared to a normal value of 25). This is most probably caused by higher levels of 1,25-dihydroxy vitamin $D_{3}$ (2). Our therapeutic diet of these patients consists of a diet moderately restricted in $\mathrm{Ca}$ $(500 \mathrm{mg} / \mathrm{d})$, oxalate ( $<400 \mathrm{mg} / \mathrm{d}$ : discourage of spinach, rhubarb, red beets; light-brewed black tea) and sodium $(100-150 \mathrm{mmol} / \mathrm{d})$. Dietary excessess of animal protein ( $>50 \mathrm{~g} / \mathrm{d}$ ) were eliminated (3).

Lower intakes of $\mathrm{Ca}$ have been associated with an increased risk of colorecral cancer (CRC) in some epidemiological studies $(4,5)$, in experimental studies in humans (6) and animals $(7,8)$. Therefore the Ca-restricted diet prescribed to hypercalciuria type II patients may enhance the risk for CRC.

This paper describes the effect of the Ca-restricred diet of our hypercalciuria type Il patients on metabolic risk factors for $\mathrm{CRC}$ : $\mathrm{pH}$, bile acids (BA), long chain fatty acids (LCFA) and cytotoxicity of faecal water (8).

\section{Methods}

The study protocol was approved by the Medical Ethics Committee of the University Hospital Maastricht (PF8).

Patients with recurrent urolithiasis were metabolically screened as described by Pak et al (1) using a computerized program. Before the metabolic screening, the patients filled in a structured dietary questionnaire (9), improved by measures for portion size and by more detailed questions about calcium, salt and oxalare-intake. Urologists of six Dutch hospitals participated in the study, using the same version (2.0.1) of the computerprogram.

Patients with an urinary Camexcretion on their regular diet $>5 \mathrm{mmol} / \mathrm{d}$ and an excretion below this value after one week on a Ca- $(400 \mathrm{mg} / \mathrm{d})$ and sodium$(100 \mathrm{mmol} / \mathrm{d})$ restricted diet, were diagnosed as hypercalciuria type II. These patients were invited to participation by their urologist, after which informed consent was obrained. Exclusion criteria were using using laxarives, cholesterol-lowering medicines, gallbladder disease and bone disorders. After the decision to participate, the patients received detailed information and materials to collect $24 \mathrm{~h}$ urine and $48 \mathrm{~h}$ faeces. The projectmanager explained 
the trial extensively to the patients by telephone and a data-plan was made together. Randomizarion between the experimental (Ca-restricted) and the control (regular diet) group were performed within strata for Ca-intake (less and more than $1000 \mathrm{mg} / \mathrm{d}$ ) and sex.

Before and after the study period of 4 weeks, fasting urine and blood were sampled in the hospital of the patient. At both sampling times a form with questions about defaecation frequencies and problems during sampling was filled in by the patients. Moreover at the end of the four weeks, the patients filled in the dietary questionnaire mentioned before, to measure dietary practices during the trial.

The dietary questionnaire of the respondents was controlled by the dietitian of the patient's hospital and calculared for $\mathrm{Ca}$ and other nutrients by a dietitian of the Dept. of Dietetics of the University hospital in Mastricht using the standardized Dutch Uniform Encoding System (10) and the 1992 release of the National Computerized Dutch Nurrient Databank, NEVO (11). This databank is prepared and regularly updated by a national committee. The experimental subjects visited their dietitian to discuss the Carestricted diet. The amount of fluid was prescribed to 2.51 per day The Ca-intake was limited to $500 \mathrm{mg} / \mathrm{d}$. In the Netherlands this is mainly achieved by omitting dairy products like cheese and other milk (producrs). No lower intake than $500 \mathrm{mg} / \mathrm{d}$ was allowed, because at low intakes of Ca, oxalate absorption might be increased. Oxalate-rich vegetables like spinach or rhubarb were discouraged. Light-brewed black tea was allowed to a maximum of 1 liter, because of its high content of oxalic acid, which may result in a high excretion of oxalate in urine. The diet was normalized in relation to animal protein $(50 \mathrm{~g} / \mathrm{d})$ and salt $(4500 \mathrm{mg}=200 \mathrm{mmol} \mathrm{Na} / \mathrm{d})$ because these dietary factors increase the Ca-excretion with urine (1). Alcoholic drinks were restricted to $4 \mathrm{drinks} / \mathrm{d}$ because the alcohol. may lead to a high excretion of Ca in urine (12).

Fasting urine was sampled after discarding the first urine of the morning at the patient's hospital. It was poured directly into a glass rube, covered with a drop of toluene and frozen at $-20^{\circ} \mathrm{C}$. Fasting blood was sampled in lithium heparin, immediately centrifuged during $10 \mathrm{~min}$ at $1500 \times \mathrm{g}$, the plasma portioned in plastic rubes and the tubes frozen at $-20^{\circ} \mathrm{C}$.

Urine during $2 \times 24 \mathrm{~h}$ was sampled by the patients on weekdays using the U-mate P of Sumitomo Bakelite Co, Tokyo, Japan with the lower part filled with $1.7 \mathrm{~g}$ boric acid as preservative. It is based on the principle of the one described by Tochikubo (13), taking $1 / 50$ of every urine voidance. With this 
small apparatus, $24 \mathrm{~h}$ urine can be sampled very easy withour carrying a big. jerrycan of 2.51 . The sampler can be cleaned and desinfected by soap and hypachlorite. Combined with a clear description of usage, about 30 man and women between 20 and 65 yrs old used this apparatus without reporting to have difficulties. We controlled the validity of urine sampling by analyzing the creatinine excretion (1).

Faeces during $48 \mathrm{~h}$ were collected in the weekend using a plastic bucket that fits into the toilet (Emergo, Landsmeer, The Netherlands) and coded plastic bags that fit into the bucket. Immediately after defaecation, the bags containing the stools were placed between four frozen elements of a freezing pack that is surrounded by sryrofoam plates in a cardboard box. In this manner sampling materials and faecal samples can be easy mailed and the samples stayed below $5^{\circ} \mathrm{C}$ during four days. Seven days before collection the patients swallowed 10 radio-opaque pellets (Resprecare Medical B.V., The Hague, The Netherlands), three times a day to correct excretion values for faecal flow (14). Each collected stool was weighed, flattened for x-raying and stored in a freezer at $-20^{\circ} \mathrm{C}$. X-rays were made using AGFA-Gevaet Curix RPI films of $24 \times 30 \mathrm{~cm}$ in Kodak $X$-omatic cassettes in a Philips camera type Practix. The samples ( 4 per plate) were illuminated at $60 \mathrm{~cm}$ distance by $50 \mathrm{kV}$ for $0.2 \mathrm{sec}$. The pellets were counted on a lighted bank.

$\mathrm{pH}, \mathrm{BA}$ and LCFA in toral faeces and in faecal water were measured as described by van Faassen (15). The cytotoxicity of faecal water was determined by a modification of the method described by Govers (16): $40 \mu \mathrm{l}$ of faecal water was mixed with $40 \mu 1154 \mathrm{mM} \mathrm{NaCl}$. After preincubation for 5 min at $37^{\circ} \mathrm{C}, 20 \mu \mathrm{l}$ of a washed human erythrocyte suspension was added (final hematocrit $5 \%$ ) and incubated for $3 \mathrm{~h}$ ar $37^{\circ} \mathrm{C}$. Each hour the tubes were vortexed. The intact erythrocytes were precipitated by centrifuging for 1 min at $1500 \mathrm{xg}$, washed three times with $154 \mathrm{mM} \mathrm{NaCl}$, and after acidification with trichloroacetic acid (final $5 \% \mathrm{w} / \mathrm{v}$ ) and subsequent centrifugation $(1 \mathrm{~min}$ at $10,000 \times \mathrm{g}$ ), the supernatant was diluted 25 times with $0.05 \mathrm{CsCl}$. The potassium content of the solution was measured by atomic emission spectrophotomerry (Perkin Elmer 1100). Simultaneously, erythrocytes were incubated in $154 \mathrm{mM} \mathrm{NaCl}(0 \%$ hemolysis) and in double-distilled water (100\% hemolysis). Percent hemolysis was calculated from these 0 and 100 controls.

In urine creatinine was measured by a colorimetric assay of the Dimension (B) clinical chemistry system (Dupont de Nemours, Wilmington,U.S.A.). Sodium was analyzed by flame spectroscopy on a photometer (model 943, Instrumentation Laboratory Incorporation, Milan,Italy), $\mathrm{Ca}$ and $\mathrm{Mg}$ on an 
atomic absorption spectrophotometer (model AAAE 551, Instrumentation Laboratory Incorporation, Milan, Italy.) with a long path air acetylene burner (IL 43005-02). Phosphare, urea and uric acid were determined as described by the Dimension(1)-system. Sulphate was analyzed by a turbidimetric method using polyethylene glycol 6000 (17). Oxalate and citrate were measured by enzymatic kits of Sigma and Boehringer, respectively.

$\mathrm{Ca}, \mathrm{Mg}$ and phosphorous in faeces were analyzed as described abowe after incubating wet faeces in $4 \mathrm{~N}$ hydrogen chloride and 7.5 hydrogen peroxide at $1000 \mathrm{C}$ for $\mathrm{I}$ hour, centifuging $10 \mathrm{~min} 3000 \mathrm{xg}$ and filtering through Filter Sampler, a standard model of blood serum filters of Porex Medical, Fairburn, Georgia, U.S.A. Their concentrations in faecal water were analyzed after incubating faccal water in 5 trichloroacetic acid during $1 \mathrm{~h}$ and centrifuging $2 \min 10,000 \times g(18)$.

Absolute values and differences in changes of dietary constituents and variables of blood, urine and faeces between experimental and control subjects were analyzed by Student's t-test or Wilcoxon test if the variables were not normally distributed. Correlations between (shifts in) parameters were calculated by the Pearson correlation coefficient or Spearman correlation coefficient if the variables were not normally distributed (19).

\section{Results}

Twenty-nine subjects from six hospitals wolunteered into the study. Six male and two female patients were invited by their urologist, but did not want to participare. Of three parients (one male and nwo females) we did not receive the dietary questionnaire, sent by mail. The fasting urine and blood of two pacients were not collected properly by their hospital. Twenty-four hour urine of four patients were not collected correctly as shown by creatinine excretion values. Two female patients refused to collect faeces and the faecal analyses of: two parients were unreliable; one because she had a gall-bladder operation and the other because the photograph of the pellets in his faeces was not valid. Therefore dictary data of 26 subjects, the data of bone metabolism of 27 subjects and urinary and faecal excretion values of 25 subjects were statistically analyzed

The values at the beginning of the trial and the changes in dietary intakes of the patients from the control and from the Ca-restricted group are shown in Table 1. The changes (value after 4 weeks minus value at the beginning) in intake of $\mathrm{Ca}$, animal protein, mono- en disaccharides, polysaccharides, 
TABLE 1

Mean (SD) of bascline values and changes in nutrients

\begin{tabular}{|c|c|c|c|c|}
\hline \multirow[t]{2}{*}{ Dietary constituent } & \multicolumn{2}{|l|}{$\begin{array}{l}\text { Control diet } \\
(n=13)\end{array}$} & \multicolumn{2}{|c|}{$\begin{array}{l}\text { Ca-restricted diet } \\
(n=13)\end{array}$} \\
\hline & baselinice & change & basaline & change \\
\hline Enctgy (KJ/d) & $9690(2830)$ & $-400(1270)$ & $12130(3650)$ & $-3420(3070)^{2}$ \\
\hline Total protein (g/d) & $75(20)$ & $.4(14)$ & $98(31)$ & $-37(24)^{*}$ \\
\hline Animal prokein $(g / d)$ & $48(17)$ & $-5(11)$ & $67(27)^{4}$ & $-33(29)^{2}$ \\
\hline Tocal fat $(\mathrm{g} / \mathrm{d})$ & $100(31)$ & $-9(19)$ & $133(45)^{\prime \prime}$ & $-46(39)$ \\
\hline Saruited fat $(g / d)$ & $40(13)$ & $-5(8)$ & $54(17)^{*}$ & $-26(13)$ \\
\hline Cholesterol (mg/d) & $237(86)$ & $-24(43)$ & $320(115)^{\prime \prime}$ & $-144(108)^{\circ}$ \\
\hline Carbohydrates $(\mathrm{g} / \mathrm{d})$ & $251(98)$ & $-3(48)$ & $317(108)$ & $-76(75)^{4}$ \\
\hline Mono + disaccharides (g/d) & $111(64)$ & $0(48)$ & $155(68)$ & $-47(64)^{*}$ \\
\hline Polysaccharides $(\mathrm{g} / \mathrm{d})$ & $140(50)$ & $-3(23)$ & $162(56)$ & $-29(35)^{*}$ \\
\hline Fibre $(g / d)$ & $28.5(9.4)$ & $1.1(7.9)$ & $27.9(8.7)$ & $-2.7(6.9)$ \\
\hline Calcium (mmolid) & $23.2(9.2)$ & $-1.5(6.9)$ & $31.2(16.8)$ & $-17.8(18.5)^{*}$ \\
\hline Phosphorous (mmol/d & $47.5(13.6)$ & $-1.1(9.5)$ & $57.9(19.3)$ & $-23.5(17.1)^{*}$ \\
\hline Sodium (mmol/d) & $182(47)$ & $-11(23)$ & $203(39)$ & $-43(23)^{*}$ \\
\hline Filuid $(1 / d)$ & $2.9(0.8)$ & $-0.11(0.7)$ & $2.9(1.0)$ & $-0.3(1.1)$ \\
\hline
\end{tabular}

$p<0.05$

pe0.01

\section{TABLE 2}

Mean (SD) baseline values and changes in urinary plus faecal excretion of minerals

\begin{tabular}{|c|c|c|c|c|}
\hline \multirow[t]{2}{*}{$\begin{array}{l}\text { Balance variable } \\
\text { (momol/d) }\end{array}$} & \multicolumn{2}{|l|}{$\begin{array}{l}\text { Control diet } \\
(n=11)\end{array}$} & \multicolumn{2}{|c|}{$\begin{array}{l}\text { Ca-restricted diet } \\
(\mathrm{n}=9)\end{array}$} \\
\hline & baselline & change & baseline & change \\
\hline calcium & $29.1(14.9)$ & $2.8(28.5)$ & $32.3(22.6)$ & $-17.0(25.4)^{*}$ \\
\hline magntusitum & $21.1(14.0)$ & $-3.1(17.8)$ & $18.8(10.8)$ & $-6.7(12.1)$ \\
\hline phosphorous & $53.4(19.3)$ & $-6.3(24.7)$ & $50.1(22.1)$ & $-11.8(221)$ \\
\hline
\end{tabular}

" $P<0.05$

cholesterol, saturated fatry acids, energy, phosphorous and sodium were significantly higher for the experimental group than the control group. The initial intake of animal protein, total fat and saturated fat were significantly higher in rhe restricted group. The Ca-intake appeared higher initially in the experimental group although not significantly. 
TABLE 3

Mean (SD) of baseline values and changes in urinary wariables

\begin{tabular}{|c|c|c|c|c|}
\hline \multirow[t]{2}{*}{ Urinary variable } & \multicolumn{2}{|l|}{$\begin{array}{l}\text { Controll diet } \\
(n=13)\end{array}$} & \multicolumn{2}{|c|}{$\begin{array}{l}\text { Ca-restricted diet } \\
(n=12)\end{array}$} \\
\hline & baseline & changt & baseline & change \\
\hline urine $(1 / d)$ & $1.6(0.4)$ & $0.06(0.6)$ & $1.7(0.8)$ & $0.05(1.1)$ \\
\hline urea $(\mathrm{mmmol} / \mathrm{d})$ & $334(102)$ & $-9.2(75.5)$ & $342(154)$ & $-31(132)$ \\
\hline sodium (mmol/d) & $153(53)$ & $-0.5(46.5)$ & $169(66)$ & $-25(88)$ \\
\hline creatinine ( $\mathrm{mmol} / \mathrm{d})$ & $13(4)$ & $0(3)$ & $13(4)$ & $-1(6)$ \\
\hline calcium $(\mathrm{mmol} / \mathrm{d})$ & $6.1(1.4)$ & $-0.2(2.5)$ & $6.3(2.3)$ & $-0.7(2.9)$ \\
\hline oxalate (mmold) & $0.38(0.17)$ & $0.05(0.15)$ & $0.43(0.25)$ & $-0.12(0.27)^{\circ}$ \\
\hline cirrate (mmol/d) & $2.4(1.3)$ & $-0.3(1.0)$ & $3.1(1.4)$ & $-0.3(1.6)$ \\
\hline sulphate (mmolid) & $17.7(8.2)$ & $-0.3(8.1)$ & $19.1(6.5)$ & $-3.8(9.0)$ \\
\hline phosphate (mmol/d) & $31.3(9.6)$ & $-1.9(6.5)$ & $33.0(13.9)$ & $-5.3(14.8)$ \\
\hline magnesium (mmol/d) & $4.7(1.4)$ & $-0.4(1.4)$ & $5.0(2.7)$ & $0.1(2.4)$ \\
\hline
\end{tabular}

$p<0.1$

TABLE 4

Mean (SD) of baseline values and changes in focal variables

\begin{tabular}{|c|c|c|c|c|}
\hline \multirow[t]{2}{*}{ Faecal variable } & \multicolumn{2}{|l|}{$\begin{array}{l}\text { Control diet } \\
(n=13)\end{array}$} & \multicolumn{2}{|c|}{$\begin{array}{l}\text { Ca-restricted diet } \\
(n=13)\end{array}$} \\
\hline & baseline & change & baseline & change \\
\hline \multicolumn{5}{|l|}{ Deffecation frequency } \\
\hline Faecal bulk (g wer weight/d) & $226(192)$ & $-2(24)$ & $229(179)$ & $-10(20)$ \\
\hline Faecal dry weight $(\%)$ & $26.1(4.6)$ & $-0.8(4.0)$ & $24.0(5.0)$ & $0.5(6.3)$ \\
\hline $\begin{array}{l}\text { Bile acids in total faeces } \\
\text { (umol/g wet weight) }\end{array}$ & $4.3(1.3)$ & $0.2(1.8)$ & $4.4(1.2)$ & $2.3(6.8)$ \\
\hline Long chain faty acids in rotal & & & & \\
\hline faeces (umol/g wet weight) & $41(18)$ & $2(27)$ & $40(29)$ & $-16(29)$ \\
\hline Bile acid excrerion (umol/d) & $907(657)$ & $-56(891)$ & $999(719)$ & $-102(1431)$ \\
\hline $\begin{array}{l}\text { Long chain farty acid } \\
\text { excretion (mmol/d) }\end{array}$ & $7.7(5.8)$ & $2.0(12.4)$ & $8.7(7.3)$ & $-5.9(7.2)^{\circ}$ \\
\hline
\end{tabular}

$p<0.1$

The combined urinary and faecal excretion values excretion values in urine and facces (Table 2) show that the experimental group excreted about 20 $\mathrm{mmol}=800 \mathrm{mg}$ less $\mathrm{Ca}$ per day during the trial than the control group. Moreover the initial data for $\mathrm{Ca}$ are equal between both groups. 
TABLE 5

Mean (SD) of baseline values and changes in variables of facal water

\begin{tabular}{|c|c|c|c|c|}
\hline \multirow[t]{2}{*}{ Variable of faecal water } & \multicolumn{2}{|c|}{$\begin{array}{l}\text { Control dier } \\
(n=13)\end{array}$} & \multicolumn{2}{|c|}{$\begin{array}{l}\text { Ca-restricted diet } \\
(n=13)\end{array}$} \\
\hline & bascline & change & baseline & change \\
\hline Water $(m \mathrm{~m} / 24 \mathrm{~g})$ & $6.9(2.8)$ & $1.0(2.3)$ & $9.0(3.2)$ & $-1.2(3.1)^{\circ}$ \\
\hline $\mathrm{pH}$ & $6.0(1.8)$ & $-0.1(0.6)$ & $6.2(0.3)$ & $-0.0(0.4)$ \\
\hline Bile acids (unoll) & $281(228)$ & $28(134)$ & $340(216)$ & $-35(107)$ \\
\hline Deoxycholic acid (umolls) & $60(60)$ & $23(68)$ & $98(65)$ & $-1.4(73)$ \\
\hline $\begin{array}{l}\text { Long chain fatry acids } \\
\text { (mmolll) }\end{array}$ & $1.5(1.9)$ & $0.2(2.2)$ & $4.2(6.0)$ & $-3.0(5.6)^{\text {से }}$ \\
\hline Cytotoxicity $(\%)$ & $51(41)$ & $21(49)$ & $74(35)$ & $-16(36)^{*}$ \\
\hline Calcium (mmollo) & $11.1(6.7)$ & $3.1(7.3)$ & $15.5(6.1)$ & $-1.9(9.5)$ \\
\hline
\end{tabular}

$p<0.1$

$p<0.05$

TABLE 6

Spearman-correlation coefficients of baseline values and changes in cytoroxicity of faecal water with other faccal water variables

\begin{tabular}{|c|c|c|}
\hline & $\begin{array}{l}\text { cytotoxicity } \\
(\%)\end{array}$ & $\begin{array}{l}\text { changes in } \\
\text { cytotoxicity }(\%)\end{array}$ \\
\hline $\mathrm{pH}$ & $-0.63^{*}$ & \\
\hline Long chain farty acids (mmol/1) & 0.74 & \\
\hline Linoleic acid (mmol/l) & $0.79^{48}$ & \\
\hline Oleic acid $(\mathrm{mmol} / \mathrm{l})$ & $0.71^{\text {斻 }}$ & \\
\hline Palmicic acid (mmol/) & $0.73^{\#}$ & \\
\hline Stearic acid (mmol/l) & $0.53^{*}$ & \\
\hline Bile acids ( $\mu$ mol/l) & $0.58^{*}$ & \\
\hline Mono + dihydroxy bile acids $(\mu \mathrm{mol} / \mathrm{)})$ & $0.65^{*}$ & \\
\hline Kerot whihyd roxy bile acids (urnol/l) & 0.04 & \\
\hline Changes in long chain bety acids & & $0.60^{\circ}$ \\
\hline Changes in bilc acids & & 0.31 \\
\hline
\end{tabular}

7 $7-K, D C, 12-K-L C, 7-K-L C$

* pod 0.01

$\mathrm{p}<0.001$

The urinary excretion of urea and sodium rended to decrease in the experimental group (Table 3) although the changes were not statistically significant. These urinary markers of dietary intake of protein and sodium respecrively (20), show that there was no difference in inital intake of these dietary constituents berween both groups. 
Mean (SD) baseline values and changes in men and women

\begin{tabular}{|c|c|c|c|c|}
\hline \multirow[t]{2}{*}{ Men } & \multicolumn{2}{|l|}{$\begin{array}{l}\text { Conntrol dier } \\
(n=9)\end{array}$} & \multicolumn{2}{|c|}{$\begin{array}{l}\text { Ca-restricted dier } \\
(n=7)\end{array}$} \\
\hline & baseline & change & baseline & change \\
\hline $\begin{array}{l}\text { Ca in } 24 \mathrm{~h} \text { urine }+ \\
\mathrm{Ca} \text { in } 24 \mathrm{~h} \text { faeces (mmol/d) } \\
\text { Urea (mmol/d) } \\
\text { Sodium (mmol/d) } \\
\text { Ca in } 24 \mathrm{~h} \text { urine (mmol/d) } \\
\text { Age (yrs) } \\
\text { Weighr ( } \mathrm{kg}) \\
\text { Body mass index }\left(\mathrm{kg} / \mathrm{m}^{2}\right)\end{array}$ & $\begin{array}{l}31.9(15.8) \\
352(102) \\
147(57) \\
6.3(1.3) \\
49(11) \\
80.1(12.2) \\
27.6(3.7)\end{array}$ & $\begin{array}{c}3.0(33.4) \\
-1(81) \\
15(35) \\
-0.8(1.4)\end{array}$ & $\begin{array}{l}38.8(24.5) \\
31.2(122) \\
178(78) \\
6.9(2.5) \\
44(10) \\
78.5(8.0) \\
25.1(1.7)\end{array}$ & $\begin{array}{l}-30.3(27.5)^{\circ} \\
-16(152) \\
-34(105) \\
-1.8(2.8)\end{array}$ \\
\hline \multirow[t]{2}{*}{ Women } & \multicolumn{2}{|l|}{$\begin{array}{l}\text { Concrol diet } \\
(n=3)\end{array}$} & \multicolumn{2}{|c|}{$\begin{array}{l}\text { Ca-restricted diet } \\
(n=5)\end{array}$} \\
\hline & braseline & change & baseline & change \\
\hline $\begin{array}{l}\text { Ca in } 24 \mathrm{~h} \text { urine }+ \\
\text { Ca in } 24 \mathrm{~h} \mathrm{faeces}(\mathrm{mmol} / \mathrm{d}) \\
\text { Urea }(\mathrm{mmol} / \mathrm{d}) \\
\text { Sodium }(\mathrm{mmol} / \mathrm{d}) \\
\text { Ca in } 24 \mathrm{~h} \text { urine }(\mathrm{mmol} / \mathrm{d}) \\
\text { Age }(\mathrm{yrs}) \\
\text { Weight }(\mathrm{kg}) \\
\text { Body mass index }\left(\mathrm{kg} / \mathrm{m}^{2}\right)\end{array}$ & $\begin{array}{l}20.5(9.1) \\
255(75) \\
181(13.2) \\
5.6(2.0) \\
57(16) \\
70.0(7.4) \\
25.0(4.5)\end{array}$ & $\begin{array}{c}2.1(2.1) \\
-47(33.2) \\
-68(20) \\
1.8(4.4)\end{array}$ & $\begin{array}{l}17.1(2.0) \\
413(227) \\
148(8.4)^{4} \\
5.6(1.9) \\
43(7) \\
70.2(14.3) \\
24.9(3.0)\end{array}$ & $\begin{array}{c}1.9(6.8) \\
-62(99) \\
-9(47) \\
1.0(2.3)\end{array}$ \\
\hline
\end{tabular}
$p<0.1$
$p<0.05$

The excretion of Ca with urine decreased, but there was no significant difference between the Ca-restricted and the control group. Moreover the variation in shifts was extremely high.

The faecal excretion of LCFA seemed to decrease on the Ca-restricted diet ( $p$ $<0.05$; Mann Whitney-test) (Table 4).

Neither the concentration of BA nor that of LCFA in faecal water raised in the experimental group. Both decreased in comparison with the control group, although the difference was only significant for LCFA (Table 5). The 


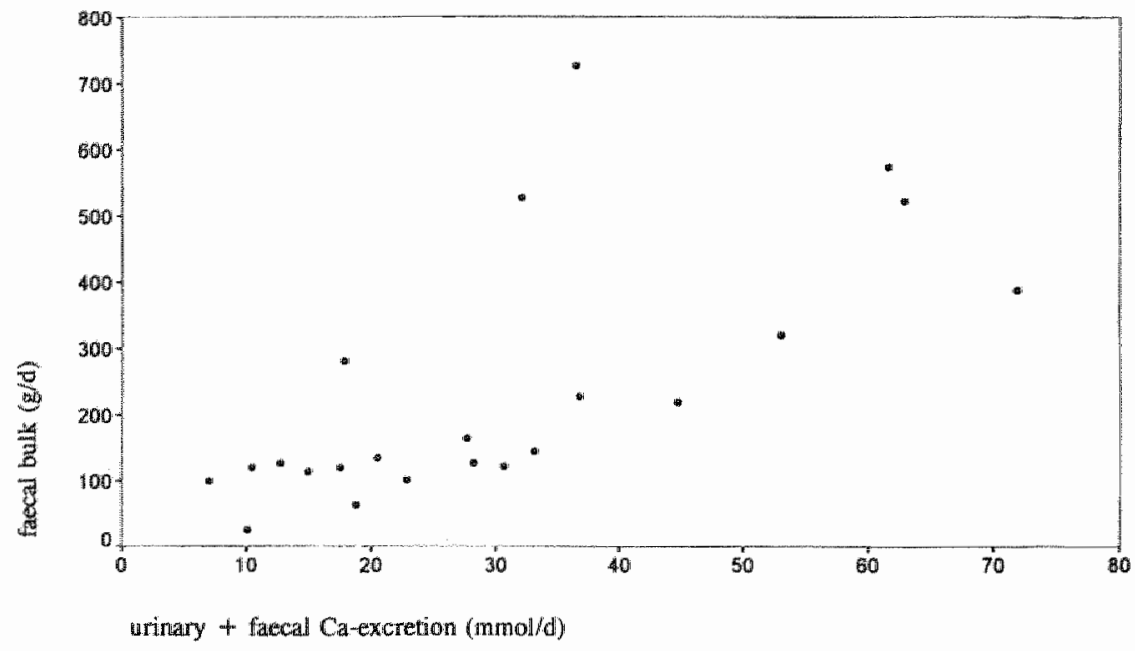

FIGURE 1

Facal bulk $=24.2+7.0$ (urinary + faecal excretion) $.5 E \beta=1.7 ; r^{2}=0.46$

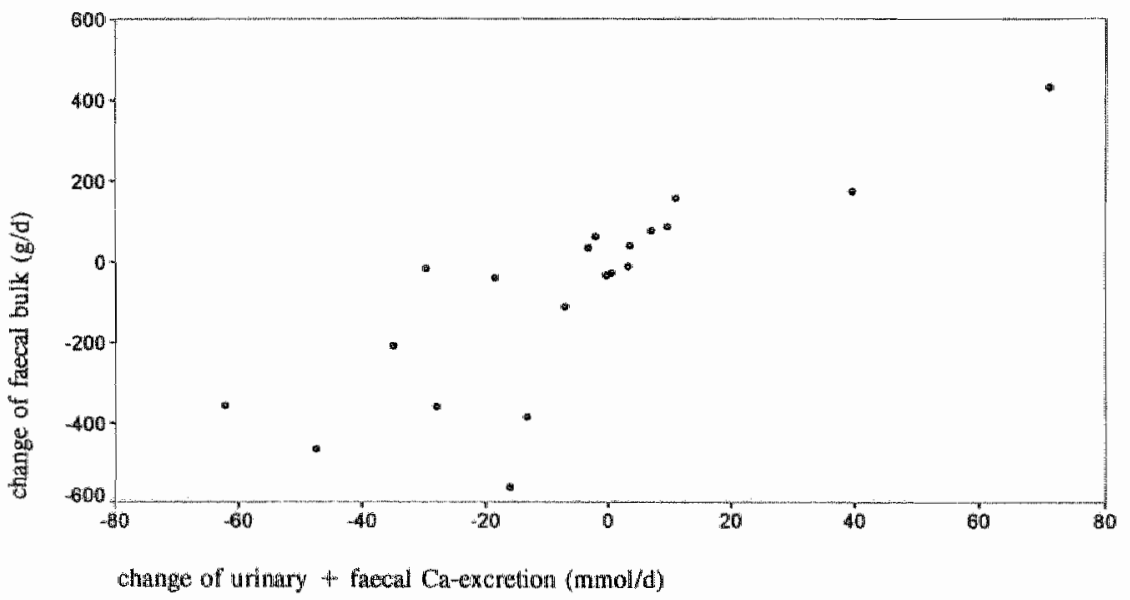

FGURE 2

Chage of facal bulk $=-35.1+6.8$ (change of urinary + faecal Ca-excretion). SE $\beta=1.1 ; \mathrm{r}^{2}=$ 0.65

$\mathrm{pH}$ of faecal water did not change due to the Ca-restricted diet., nor did the concentration of $\mathrm{Ca}$ in faecal water. The cytotoxicity of faecal water decreased. significantly in the experimental group $(\mathrm{p}<0.05)$.

Sixty-one percent of the variance in baseline values of faecal bulk could be explained by sex, fibre intake and intake of Ca calculated from the urinary + 
faecal excretion of Ca: ${ }^{10} \log$ faecal bulk $(\mathrm{g} / \mathrm{d})=0.37-0.06$ sex $(1=$ man; $2=$ woman $)+0.51^{10} \log$ fibre intake $(\mathrm{g} / \mathrm{d})+0.87^{10} \log$ (Ca-excretion in faeces + urinary Ca-excretion) (mmol/d). The increase of faecal bulk by increasing intake of Ca was most prominent above $25 \mathrm{mmol} / \mathrm{d}(=1,000 \mathrm{mg} / \mathrm{d}$ ) (Figure 1). Also seventy-one percent of the variance in change of facal bulk could be explained by the change in intake of fibre and $\mathrm{Ca}$ (see also Figure 2).

The baseline values of cytotoxicity of faecal water was significantly correlated with those of $\mathrm{pH}$, concentration of LCFA and concentration of $\mathrm{BA}$ in faecal water. The correlation was highest with the LCFA. The sum of the concentrations of the secondary BA (the hydrophobic ones) was correlated more strongly with cytotoxicity than total BA in faecal water. The correlation was lowest for the sum of the hydrophilic BA. The change in cytotoxicity was correlated significantly with the change in LCFA (Table 6).

\section{Discussion}

The excretion data of $\mathrm{Ca}, \mathrm{Mg}$ and phosphorous and biomarkers of dietary intake like urea indicated no difference in dietary intake of both groups. The difference in dietary intake data may be caused by an underreporting of the intake of e.g. milkproducts by the control group. This group happened to contain three time more subjects with a body mass index higher than 26 , including two with an index higher than 30 . Such persons are more likely to under report their dietary intake $(H$. Boeing, personal communication).

The Carrestricted diet did not significantly lower Ca in urine. Moreover the variability in the change was extremely high: the Ca-excretion of some patients in the experimental group even increased. When males and females were separated (Table 7), it seemed that the Ca-excretion in urine and the Ca-balance increased in women and decreased in man while in both the intake of Cat, protein and salt decreased. Exclusion of two postmenopausal women did not change the results. A lowering effect of a 4 days severe Ca-restriction $(250 \mathrm{mg} / \mathrm{d})$ has been derected in male, hypercalciuric renal stone forming subjects (21). A Ca-restriction to $400 \mathrm{mg} / \mathrm{d}$ and moderate sodium restriction during 4 days lowered the Ca-excretion in hyperalcuria type II parients (22). The small effect in the male patients of our srudy might be caused by an increase of calcitriol in serum when subjects are maintained on a low $\mathrm{Ca}$-diet for at lease 10 days (23).

The lower excretion of oxalate will have been caused by the omirting of protein from dairy products and the lower intake of carbohydrates during the Ca-restricted diet. The expected higher excrevion of oxalate due to an enhanced solubility of oxalate in the intestine and therefore an increased absorp- 
tion of oxalate, may play a minor role when the subjects are consuming already a diet moderately restricted in oxalate (24). On the other hand the effect of a lower intake of protein, fat and carbohydrates may be stronger than the lowered intake of $\mathrm{Ca}(25)$.

The Ca-restricted diet did not influence the urinary excretion of cirrate. It was already suggested (26), that dairy protein did not lower the citrate excretion, although dairy protein is a form of animal protein. Dairy products may contain constituents that lead to a lower acidification in the nephron and therefore to less lowering of the cirrate excretion. This hypothesis is supported by our data on sulfate in $24 \mathrm{~h}$ urine (Table 3 ) which were not changed by the experimental diet.

The diminishing concentration of BA and LCFA in faecal water will most probably be caused by the lower intake of far that accompanies the $\mathrm{Ca}$-restriction in these patients due to omission of dairy products. Based on the regression equation derived from our previous cross-sectional study (27) a decrease of about $90 \mathrm{umol} / \mathrm{l}$ could be predicted by the decrease in saturated fat. The expected enhancing effect of the lower intake of $\mathrm{Ca}$ as derived from the data of van der Meer and Govers (28) would be about $40 \mathrm{umol} / \mathrm{l}$. Therefore the decreasing effect of our Ca-restricted diet is predominating.

The enhancing effect of $\mathrm{Ca}$ on BA in faecal water may be explained by the increase of faecal bulk due to an increase of Ca-intake above $1000 \mathrm{mg} / \mathrm{d}$. This effect has been reported before for humans and rats $(29,30)$ and may be caused by a higher excretion of fatty acids due to their reduced absorption. In our previous cross-sectional study (27), the concentration of the main BA in faecal water, DC, was lower in subjects having higher faecal bulks.

The cytotoxiciry of faecal water diminished significantly on the diet. This agrees with the diminuation of the concentration of BA and LCFA in faecal warer. The higher correlation between cytotoxicity and LCFA than between cytotoxicity and BA has been reported before (31).

A negative correlation between the cytotoxicity and the $\mathrm{pH}$ of faecal water has not been reported before. It occured also after the dietary intervention, although the correlation was lower $(r=-0.35 ; p<0.1)$. It is not caused by a correlation between $\mathrm{Ca}$ in faecal water and cytotoxicity, because this correlation was positive (Spearman correlation coefficient of 0.14 ). It may be caused by the unionized form of $\mathrm{DC}$, which will be present at higher concentrations at this $\mathrm{pH}$, because the $\mathrm{pKa}$ of DC varies between 5 and 6.6 (32). Van der Meer et al (33) have shown that hydrophobic BA are more cytolytic than the 
hydrophilic ones. Unionized BA are more hydrophobic than the ionized ones. The in vitro inhibiring effect of a lower $\mathrm{pH}$ on the damaging effect of $5 \mathrm{mM}$ DC to the rat colon reported by Rafter et al (34), may be due to a decreased amount of DC in solution. This effect may not be relevant for the physiological siruation because DC concentrations in faecal water are only about 0.1 $\mathrm{mM}$. The lysis of erythrocytes by faecal water correlates very well with those for $\mathrm{CaCo}-2$ cells derived from a human colon adenocarcinoma cell line (35) and with hyperproliferation of colonic cells in rats (8).

Lapré et al (36) found higher concentrations of $\mathrm{Ca}$ in faecal water after supplementation with Ca-carbonate from 1200 to about $3000 \mathrm{mg} / \mathrm{d}$, but Govers et al (16) found no significant increase after supplementation with $\mathrm{Ca}$ from milk products from 800 to about $1800 \mathrm{mg} / \mathrm{d}$. Therefore in normal dietary situations the concentration of $\mathrm{Ca}$ in faecal water is probably not influenced by dietary intake of $\mathrm{Ca}$. Although a low concentration of $\mathrm{Ca}$ in faecal water may enhance CRC (37), no epidemiological or animal studies have been performed on this subject.

Correlations between dietary variables and faecal biomarkers were similar to those reported by us before for omnivores and vegetarians (28), except the correlation between Ca-intake and faecal $\mathrm{pH}$ and that between DC in faecal water and intake of saturated fat. In this study, the correlation between the $\mathrm{pH}$ of faecal water and $\mathrm{Ca}$-intake was very low $(0.09)$, but the correlation with $\mathrm{Ca}$ in faeces was statistically significant (Pearson correlation coefficient of 0.52, $\mathrm{p}$ $<0.05)$. Baseline data of daily faecal wet weight and defaecation frequency were significantly higher in men than in women. Also, 26 of the variance in defaecation frequency was explained by sex and the intake of dietary fibre ( $P$ $<0.05$ ). The variance in the concentration of DC in faecal water could not be explained significantly by dietary factors. The reasons may be the lower validity of the food frequency questionnaire compared to the dierary history method and the lower variability in faecal DC and saturated far intake in the urolithiasis patients compared to the omnivores and vegetarians.

The decrease in intake of animal protein and saturated fat will have been caused by the omitring of dairy products like milk and cheese due to the restriction of $\mathrm{Ca}$. The subjects most probably did not substitute their milkproducts. This may be due to their high dietary intake: the intake of protein, carbohydrates and energy were respectively $8 \mathrm{~g}, 50 \mathrm{~g}$ and $1350 \mathrm{~kJ}$ higher than the age and sex controlled values of healthy subjects in The Netherlands (38). This is reflected in the high body mass indices of about half 
of the parients. The lower intake of carbohydrates during the diet may be due to a lower intake of sweetened milkproducts like chocolate milk and puddings.

The therapeutic regimen of drinking more than 2.51 water per day was not followed by all patients as can be derived from their volume of daily urine. The difference between intake and excretion might be about $0.5-11$ (1). On the Ca-restricted diet three patients drank much less than on their normal diet. Most probably they didn't compensate for their lower intake of milk and milkproducts.

In stead of omitting dairy products, which are valuable sources of nutrients like vitamin $\mathrm{B}_{2}$, potassium and fluid, the diet should be restricted to $0.5 \mathrm{~g} / \mathrm{kg}$ ideal body weight of animal protein and $3100 \mathrm{mg}$ sodium (a prudent diet). This would lower the Ca-excretion in urine about $2 \mathrm{mmol} / \mathrm{d}(39,40)$, would not lower the intake of fluid, would favor bone absorption due to its high ratio Ca:protein, would lower the concentration of BA in faeces (41) and can be checked easily by measuring urea and sodium in $24 \mathrm{~h}$ urine. On the other hand if dietary regimens are not followed, medical therapy by thiazide + potassium citrate + sodium restriction varied with cellulose phosphate + magnesium +oxalate restriction is possible (42). However these therapies are much more complicated than a prudent + high fluid diet.

In conclusion, our diet of hypercalciuria type II patients will be a small benefit for male patients and will not enhance their risk for CRC because it lowers the excretion of $\mathrm{Ca}$ and oxalate in urine and does not enhance the concentration of BA and/or LCFA in faecal water. Also it does not affect the pH of faecal water and its cytotoxicity. For women, it may be the opposite and for them a diet restricted in animal protein and table salt may be more effective against urolithiasis, safer for their bones and of equal protection against CRC.

\section{Acknowledgements}

Urologists, clinical chemists and dietitians of the Carolus hospital, the Groot Zickengasthuis and the Willem-Alexander hospital 's- Hertogenbosch, St. Maarensgasthuis, Venlo, St. Elisabeth hospital, Tilburg, and Sophia hospital, Zwolle are thanked for their cooperation. S de Kort, urologist in the Carolus hospital in "s-Hertogenbosch is acknowledged for his computerized screening program, ms. Denise Termont of the Netherlands Institute for Dairy Research, Ede, for the determination of faecal cytotoxicity, Mrs. Sigrid Bokkerink and Mrs. Esther Debie, dietitians for comparing the dietary habits of the patients with those of the general Dutch population and Mrs. Saskia Houterman for analyzing the sulphate concentration in urine. The patients 
who volunteered in the study are gratefully acknowledged for their cooperation. The study was supported financially by the Dutch Dairy Foundation on Nutrition and Health.

\section{References}

1. Pak, C.Y.C. General guidelines in medical evaluation. In: Uolithiasis: a medical and surgical reference. Edited by M.I. Resnick and C.Y.C. Pak. Philadelphia: W. B. Saunders Company. chpt 11, pp 153-171, 1990.

2. Coe,F.L., Bushinsky, D.A. Parhophysiology of hypercalciuria. Am. I. Physiol. (Renal Auid Electrolyte Physiol. 16) 247 (1984) E 1-F13.

3. Pak, C,Y.C., Smirh, L.H., Resnick, M.I., Weinerth, J.L. Dietary management of idiopathic calcium urolithiasis. J. Urol. 131 (1984) $850-852$

4. Porter, J.D., Slatcery, M.L., Bostick, R.M., Gapstur, S.M. Colon cancer: a review of the epidemiology. Epidemiol. Rev. 15 (1993) 499-545

5. Kampman, E., Goldbohm, R.A., Van den Brande, P.A., van "r Veer, P. Fermented dairy products, calcium and colorectal cancer in the Netherlands Cohort Study. Cancer Res. $54(1994) 3186-3190$

6. Wargovich, M.J., Lsbell,G., Shabot, M., Win, R., Lanza, F., Hockman, L., Larson, E.; Lunch, P., Roubein, L., Levin, B. Calcium supplementation decreases rectal epithelial cell proliferation in subjects with sporadic adenoma. Gasmoenterology 103 (1992) 92-97

7. Sitrin, M.D., Halline, A.G., Abrahams, C., Brasieus, T.A. Dietary calcium and vitamin D modulate 1,2-dimethylhydrazine-induced colonic carcinogenesis in the rat. Cancer Res. 51 (1991) 5608-5613

8. Lapte, J.A., De Vries, H.T., Koeman, J.H., Van der Meer, R. The antiproliferarive effeck of dietary calcium on colonic epithelium is mediared by luminal surfactants and dependenc on the rype of dietary fat. Cancer Res. 53 (1993)784-789

9. Grootenhuis, P.A., Westenbrink, S. Sie, C.M.T.L., Neeling, J.N.D. de, Kok, F.J., Bouter, L.M. A semiquantitative food frequency questionnaire for use in epidemiological research among the elderly. Validation by comparision with dietary history. J. Clin. Epidemiol. 48 (1995) 859-868

10. Hautvast JGA]. Commissie uniforme codering voedingsmiddelen: ontwikkeling wan cen systeem om gegeverss van woedingsenqueres met behulp vala de computer te verwerken. Voeding 36 (1975)356-360

11. Voorlichtingsbureau voor de Voeding. NEVO table. Durch food composirion tablic 1991-1992. The Hague, The Netherlands: Voorlichtungsureau voor de Voeding, 1992

12. Zechner, O., Latal, D., Pluger, H., Scheiber, V. Nurritional risk factors in urinaty stone disease 1 . Urology 125 (1981) $51-54$

13. Tochikubo, O. Uneda, S., and Kancko, Y. Simple portable device for sampling whole day's urine and its application to hypertensive outpatients. Hyperticnsion 5 (1983) $270-274$

14. Branch, W.J., Cummings, J.H. Comparison of radio-opaque pellets and chromium sesquiloxide as inert markers in studies requiring accurate faccal collection. Gut 19 (1978) $371-376$

15. Van Faassen, A., Van den Bogaard, A.E., Hazen, M.J. Janknegt, R.A. Effects of a calcium binder on the solubility of bille acids and fatcy acids in the large intestine of the rat. Cancer Let. 81 (1994) 77-80 
16. Govers, M.J.A.P. Temon, D.S.M.L., Lapre, J.A., Kleibeuker, J.H., Vonk, R.J., van der Meer, R. Calcium in dairy producrs precipitates intestinal surfactants and decreased cytolytic acriviry of fecal warce in healthy subjects. In: Govers, MU.J.A.P. Dietary calcim and phosphate in the prevention of colorectal cancer. Thesis University of Groningen, Groningen, 1993, p. 116-134

17. Lundquist, P., Martensson, J., Sorbo, B., Ohman, S. Turbidimetry of inorganic sulfare, cster sulfate and total sulfare in urine. Clin. Chem. 26 (1980) 1178-1181

18. Meer R van der, Welberg JWM, Kuipers E, Kleibeuker JH, Mulder $\mathbb{N H}$, Termond, DSML, Vonk RI, Vries, HT de, Vries EGE de. Effect of supplemental dietary calcium on the intestinal association of calcium, phosphate, and bile acids. Gastroenterology 99 (1990)1653-1659

19. Armitage, P., Berry, G. Scaristical methods in medical research. Oxford: Blackwell,1987

20. Bates, C.Jl, Thurnham, D.I., Bingham, S.A. Margetts, B.M. and Nelson, M. Biochemical markers of nutritional intake. In: Design concepts in nutritional epidemiology. Edited by B.M. Margetes and M. Nelson. Oxford: University Press. chapt. 7, 1991, p 192-265

21. Marshall, R. W., Cochran, M., Hodgkinson, A. Relationships berween calcium and oxalic acid intake in the diec and their excretion in the urine of normal and renal-stone-forming subjecrs. Clin. Sci. 43 (1972) $91-99$

22. Bataille, P., Achard, J.M., Fournier, A., Boudailliez, B., Wesreel, P.F., Esper, N.E. ct all. Diet, vitamin $D$ and wertebral mineral density in hypercaliciuric calcium stone formers. Kidney Intern. 39 (1991) 1193-1205

23. Broadus, A. E, Insogna, K.L., Lang, R, Ellison, A.F., Dreyer, B.E. Evidence for disordered control of 1,25 dihydroxyvitamin $D$ production in absorptive hypercalciurias. $N$. Engl. J. Med. 31 (1984) 73-80

24. Massey, L.K., Roman Smith, H., Surron, R.A. Effect of dierary oxalate and calcium on urinary oxalate and rusk of formation of calcium oxalate kidney stones. I An Diet Assoc. $93(1993) 901-906$

25. Tiselius, H..G. Oxalate and renal stone formation. Scand. J. Urol. Nephrol. 535 (1980) $135-148$

26. Hu, J.F., Zhoa, X.H., Parpia, B., Campbell, T.C. Dietary intakes and urinary excrerion of calcium and acids a cross secrional study of woman in China. Am. J. Clin. Nutr. 58 (1993) 398-406

27. van Faassen, A., Hazen, M.l., Brandt, P.A. van den, Bogaard, A.E. van den, Hermus, R.J.J. and Janknegr, R.A. Bille acids and $\mathrm{pH}$ values in total feces and in fecal warer from habitually omnivorous and vegetarian subjects. Am. J. Clin. Nutw. 58 (1993) 917-922

28. Van der Meer, R., Govers, M.J.A.P., Kleibeuker. J.H. Diekry calcium, bile acids, and colon cancer. In: Bile acids in gastroenterology. Basic and chinicall advances. Hofmann, A.F., Paumgarmer, G., Striehli, A. (ed), Klowwer Acadenic Press, Dordreche, 1995, p. $302-311$

29. Saunders, D., Sillery. I., Chapman, R. Effect of calcium carbonate and aluminium Mydroxide on human intestual function. Dig. Dis. Sci. 33 (1988) 409-413

30. Lupton, J.R., Chen, X.-Q. Frolich, W., Schoeffler, G.L. Peretson, M.L. Rars fed high fat diets with increased calcium levels have fecal bile acid concentrations similat to those of rass fed a low far diet.. I. Nurr. 124 (1994) $188-195$

31. Kkibeuker, J.H. Boersma-wan Ek, W.Lycic activiry of fecal water of parients with diarrea. Gastroencerology 106 (1994) A403

32. Roda, A., Fini, A. Effect of nuclear hydroxy subscituents on aqueous solubility and acidic strength of bile acids. Hepatology 4 (1984) $725-765$ 
33. Lapré, J.A., Termont, D.S.L.M., Groen, A.K., Van der Meer, R. Lytic effects of mixed micelles of farty acids and bile acids. Am. J. Physiol. 263 (1992) G333-G337

34. Van der Meer, R. Termont, D.S.M.L., De Vries, H.T. Differential effects of calcium ions and calcium phosphate on cytotoxicity of bile acids. Am.J. Physiol. 260 (1991) G142-147

35. Rafter, J.J. Eng, V.W.S., Furrer, R. Medline, A., Bruce, W. R. Effecs of calcium and pH on the mucosal damage produced by deoxycholic acid in the rat colon. Gut 27 (1986) $1320-1329$

36. Lapre, ].A. de Vries, H.T., Termont, D.S.M.L. Kleibeuker, J.1., de Vries, E.G.E., van der Meer, R. Mechanism of the protective effect of supplemental dietary calcinm on cyrolytic activiry of fecal water. Cancer Res. 53 (1993) 248-253

37. Buset, M., Lipkin, M., Winawer, S., Swaroop, 5., Friedman, E. Inhibirion of human colonic epichelial cell proliferation in wivo and in virro by calcium. Cancer Res. 46 (1986) $5426-5430$

38. Lowik, M.R.H., Brussard, J.H., Hulshof, K.F.A.M., Kistemaker, C. Schaafsma, G., Ockhuizen, T, and Hermus, R.J.J. Adequacy of the diec in the Netherlands in 1987-1988 (Dutch nutricion surveillance system). Int. ). Food Sci. Nutr. 45 (1994) 51 -562

39. Burris, W.J., Gay, L., Insogna, K.L., Ellison. A., Broadus, A. Dietary hypercalciuria in patients with calcium oxalate kidney stones. Am. J. Clin. Nurr. 60 (1994) $424-429$

40. Brestau, N.A., Brinkley, L., Hill, K.D., Pak, C.Y.C. Relationship of animal protein-rich diet to kidney stone formation and calcium metabolism. J. Clin, Endocrinol. Metabol.66 (1988) $140-146$

41. Van Faassen, A., Bol, J., Van Dokkum, W., Pikaar, N.A., Ockhuizen, T., Hermus, R. J.). Bile acids, neutral steroids, and bacteria in feces as affected by a mixed, a lacto-ovovegetarian, and a vegan diet. An. J. Clin. Nutr. 46 (1987) 962-967

42. Pak, C.Y.C. Enology and treatment of urolichiasis. Am. J. Kidney Dis. 18 (1991) $624-637$ 



\section{General discussion and conclusions}

\subsection{Introduction}

In this thesis we reported about the effect of habitual dietary pattern (omnivorous, vegetarian, vegan and $\mathrm{Ca}$-restricted) on the faecal markers of effective dose related to CRC risk that were known in 1990: bulk, $\mathrm{pH}$, defaecation frequency, secondary BA, LCFA and butyrate, one of the main SCFA. Our studies were based on the hypothesis that meat, dierary fibre and Ca are related to $C R C$ risk and that biomarkers of the biologically effective dose occur in the faecal stream.

The faecal markers that uptill now are most strongly related to CRC risk and most sensitive to dietary modulation, are secondary $\mathrm{BA}$ and daily faecal bulk. A low concentration of secondary $B A$ and a high faecal bulk, which are the result of a diet low in saturated fat, high in dietary fibre and resistant starch, may prevent hyperproliferation of colorectal mucosal cells. A low proliferation activity means a decreased DNA replication, and therefore a lower chance that mutations are fixed and will lead to neoplastic cells (1).

Other potential faecal markers of the biologically effective dose are the concentration of LCFA in faeces and/or faecal water and the concentration of $\mathrm{Ca}$ and/or $\mathrm{Mg}$ in faecal water (this thesis), the activity of the bacterial enzyme $\beta$-glucuronidase in faeces (2), the concentration of diacylglycerol in faeces (3) and the in vitro production of butyrate (4).

In this chapter the results of our studies with widely different designs (analytical chemistry, metabolic, epidemiological correlation, animal and human experimental, clinical trial) will be discussed in relation to:

1. the results of other studies of dietary effects on faccal markers of exposure

2. new knowledge on the relation between these and other faecal markers and $C R C$ risk

3. new data about dietary and environmental factors and CRC risk. 
The significance of the results for CRC risk of an omnivorous, vegetarian and ovo-lacto-wegetarian diet and of the Ca-restricted diet of urolithiasis patients is discussed.

At the end, a model is proposed how diet may influence CRC risk by constituents of the faecal stream and how patients with Ca-oxalate stones should be metabolically diagnosed and treated by dietary measures.

\subsection{Analysis of faecal bile acids}

The validity and reproducibility of the analysis of faecal BA has been studied in detail. The developed GLC-method is accurare and valid for the main BA in human faeces (chapter 2). New techniques like capillary GLC prompted us to modify the method, which could measure also the $3 \beta$-isomers of the main $B A$ in human faeces (chapter 3 ). For the measurement of the low concentrations of BA in faecal water, another capillary GLC column and other derivatives of the $B A$ have to be used. Also enzymatic deconjugation and solvolysis were omitted because in healthy subjects without gastrointestinal pathology only a minor amount of faecal BA occur as conjugates or sulphates (chapter 4). Compared to other published methods from laboratories in Munich (5), Helsinki (6) and Wageningen (7) our method of chapter 4, which was described in detail in De Kok et al (8), gives identical results for the main BA. in human faeces (Table 1).

\section{TABLE 1}

Concentrations (mmol/g dry weight) of BA in a pool sample of freeze-dried faeces from 40 healthy subjects (9)

\begin{tabular}{lllll}
\hline & Wageningen & Helsinki & Munich & Mastriche \\
\hline Lithocholic acid & 4.1 & 4.5 & 3.8 & 4.3 \\
Deoxycholic acid & 5.3 & 10.4 & 6.2 & 5.0 \\
Chenodeoxycholic acid & 0.2 & 0.5 & 0.4 & 0.2 \\
Chonic ncid & 0.3 & 0.9 & 0.6 & 0.3 \\
\hline
\end{tabular}

The remarkably higher BA concentrations found by the Helsinki laboratory may relate to their habit to consider all peaks in the gaschromatogram that appear afrer LC as BA. However, analysis by GLC-mass spectromerry performed by Glatz and coworkers revealed that this faecal pool contains appreciable amounts of compounds that can not be identified as BA. (Glatz and Stellaard, personal communication). 
Simplified methods like the enzymatic method (10), the one which measures BA and LCFA in one GLC run (11) or a recently published method using high performance liquid chromarography (12), do not measure all individual $\mathrm{BA}$ correctly. The $3 \mathrm{~B}$-isomers of the BA are not measured in the enzymatic method and are not reported by the other methods. Moreover, the other methods do not report data about 7-and 12-keto BA. LC and DC and their $3 \beta$-isomers and the 7 -and the 12-keto BA are called secondary BA, because they are produced by the bacteria of the large intestine from the primary BA chenodeoxycholic and cholic acid. These primary BA are formed in the liver from cholesterol.

\subsection{Faecal bulk and faecal bile acids}

In our metabolic ward study with an omnivorous, lacto-ovo-vegetarian and vegan diet (chapter 3), the concentration of the main faecal BA, DC, was reduced by a large amount of dietary fibre and enhanced by a high amount of $\mathrm{Ca}$ in the diet. Dietary fibre increased the daily faecal bulk (13), and therefore lowered the concentration of DC. Ca will have increased the excretion of DC by gastrointestinal binding to insoluble $\mathrm{Ca}$ (14). There was a positive correlation between faecal bulk and $\mathrm{Ca}$-intake in the study with habitual omnivores and vegetarians: $r=0.28 ; P>0.1$ (chapter 4) and in the trial with urolithiasis patients (chapter 7): $r=0.68 ; \mathrm{P}<0.01$. Moreover, in this study the change in Ca-intake correlated significantly with the change in faecal bulk. An increase of the Ca-intake above $1000 \mathrm{mg} /$ day increased faecal bulk in rats and humans $(15,16)$. It may be caused by a higher excretion of $\mathrm{Ca}$ and of fatty acids due to their reduced absorption. Faecal bulk is also increased by intake of "resistant starch' (17) and intake of an inhibitor of starch digestion (18). The larger faecall bulk of males compared to females was confirmed in our studies (chapter 4 and 7 ).

Faecal bulk was negatively associated with CRC-incidence in a correlation study in England. A bulk higher than $200 \mathrm{~g} /$ day would decrease the CRC risk 3 times to values like that of Japan. Daily stool weight is highly correlared with transit time (and defaecation frequency) until $150 \mathrm{~g}$ faeces/day (19).

The intake of dietary fibre, especially from vegetables, is consistently and negatively correlated with the risk of CRC in retrospective studies (19-22). No clear association between fibre or vegetable intake and colon cancer risk in 
men was found in a prospective epidemiological study (23), but in a prospective study in women, the group with the highest animal fat and lowest crude fbre intake had the highest risk of colon cancer (24).

The ratio CDC to ILC + LC (primary to secondary BA) was significandly higher on the vegan diet than on the omnivorous diet (chapter 3 ), which was probably caused by the $\mathrm{pH} 6.7$ of three-fold diluted faeces. This ratio did not differ berween habitual ommivores and vegetarians (chapter 4 ). The ratio primary to secondary $\mathrm{BA}$ decreased after subcotal colectomy in familial adenomatous polyposis patients. It was atributed to the absence of the colon with his bacterial flora and the $\mathrm{pH} 5.5$ of two-fold diluted faeces (25). The dehydroxylarion enzyme which converts primary to secondary $B A$, is inhibited in vitro at a $\mathrm{pH}$ lower than 5.5 (26). At more usual conditions like a lacto-ovo-vegetarian (chapter 4) or a Ca-restricted dier (chapter 7), no significant correlation between faecal $\mathrm{pH}$ and the ratio primary to secondary $\mathrm{BA}$ in faeces was found.

Neither the concentration of faecal $B A$ nor the ratio hydrophobic (mono+dihydroxy) to hydrophylic (keto+trihydroxy) BA (26) differed between habitual omnivores and vegetarians. However the concentration of $\mathrm{BA}$. in the aqueous part of the faeces was lower in the vegetarians. Moreover defaecation frequency and faecal buk were higher in this population. Thirty percent of the variance in the concentration of DC in faecal water was explained by the intake of sarurated fat, while twenty-four percent could be explained by the intake of cholesterol. Twenty percent of the variance in faecal bulk could be explained by the intake of dietary fibre, especially from fruit and vegetables. Also, faecal bulk was higher in men than in women (chapter 4).

In our study in rats and humans with dietary Ca-binders (chapter 5 and 6), neither the concentrations of BA and LCFA in caecal and faecal water respectively, nor the ratio hydrophobic to hydrophilic $\mathrm{BA}$ or the $\mathrm{pH}$ were influenced by a lower availability of $\mathrm{Ca}$ and $\mathrm{Mg}$. On the other hand, the concentrations of BA and LCFA in total faeces decreased. The results may be explained by the lowering of the bioavailability of Ca below $1000 \mathrm{mg} / \mathrm{day}$ : there are indications from literature $(15,16)$ that Ca-supplementation above $1000 \mathrm{mg} /$ day increases faccal bulk. In our cross-sectional study (chapter 4) no relation was found between faecal $\mathrm{pH}$ and Ca-intake below $1000 \mathrm{mg} / \mathrm{day}$. A higher faecal bulk will decrease the concentration of BA in faecal water as can be derived from our study with the habitual omnivores and vegetarians (chaprer 4). This may be the result of binding of BA to solid material such as calcium ions. Moreover, the fat content of the diet during the trial with Calcisorb was much lower than the amount for which Newmark et al. (27) 
proposed their hypothesis, that a diet high in Ca and Mg may lower CRC risk by making BA and LCFA less water-soluble. This hypothesis may be only valid at high intakes of saturated fat, which lead to high faecal concentrations of BA and LCFA. Such an effect has been found for Ca in rats (28).

The Ca-restricted diet of hypercalciuria type II patients lowered the concentrations of BA in faecal water and also the cytotoxicity of faecal water, but faecal pH did not change (chapter 7). This may be due to the lower intake of saturated fat that unintentionally accompanied the Ca-restriction in these patients due to omission of dairy products. Based on the regression equation derived from our previous cross-sectional study (chapter 4), a decrease of about 90 umol// BA could be predicted by the decrease in saturated fat. The expected enhancing effect of the lower intake of Ca as derived from the data of van der Meer and Govers (29) would be about $40 \mu$ mol/l. Therefore the lowering effect of the diet is predominating. The ratio hydrophobic to hydrophilic BA did not change after Ca-restriction, as would be expected by the data of Lapré et al (30). They found a decrease in the ratio hydrophobic to hydrophilic BA in faecal water after Ca-carbonate supplementation of volunteers to $3000 \mathrm{mg} /$ day but no lower concentration of BA in faecal water. This was ascribed to the low baseline values of BA in faecal water. Govers and van der Meer (29) supplemented volunteers with Ca from milk products to $1800 \mathrm{mg} /$ day and found a lower concentration of BA in faecal water. This result may have been caused by the higher daily faecal weight after Ca-supplementation.

In a large randomized trial with men, no changes in the concentration of $B A$ in faecal water were detected after supplementation with $3000 \mathrm{mg} \mathrm{Ca-car-}$ bonate, but a statistically significant increase in the concentration of DC in faecal water (31). However, their method of isolating faecal water is disputable, because they dilute faeces $1: 1$ with water before centrifuging. In this way, an equilibrium between the concentrations of $B A$ in the solid and in the aqueous phase of the faeces may be disturbed.

A recent, small study in which was corrected for factors influencing BA excretion like cholecytectomy and liver function, and in which faeces were sampled during 5 days, showed that faecal BA were statistically significant higher in patients with adenomatous polyps in the large intestine than in controls. Also CRC patients had higher concentrations than controls although this difference was not statistically significant (32). Adenomatous polyps are considered as precursors of CRC (33). In a randomized trial of a low-fat, high-fibre diet to prevent the recurrence of colorectal polyps, the rate of neoplastic polyp recurrence increased with the concentration of BA in faeces (34). In an in vitro study using colon cancer cell lines, the cytotoxicity 
of the $\mathrm{BA}$ at concentrations occuring in faecal water, increased with the hydrophobicity of the BA and the time of exposure (35). The mechanism underlying the cytotoxicity of $\mathrm{BA}$ is most probably the activation of protein kinase $\mathrm{C}$, directly or indirectly by stimulating the formation of diacylglycerol (36). Protein kinase $C$ is a key enzyme in cell proliferation (37).

Not all epidemiological studies found an increased CRC risk after a diet high in saturated (animal) fat. Most studies found a positive relation with red meat (23) and eggs (38). The mode of cooking red meat may be an additional risk factor, because during the process of cooking or frying at high temperatures, heterocyclic amines are formed. These substances are activated to carcinogenic compounds by the cytochrome P450 system of liver and intestine and transported by the blood to different organs. The metabolic activation is increased in rapid metabolizing phenorypes and by smoking (39). Eggs may be a risk factor because these food products contain unsaturated fatty acids and cholesterol, which combination has been shown to increase faecal bile acid excretion in humans (40). Moreover, the lecithin in eggs is a powerfull inducer of the gallbladder contraction, thereby increasing the faecal excretion of BA.

\subsection{Defaecation frequency}

The role of defaecation frequency in CRC-risk is still unknown. In the Dutch cohort study on diet and cancer (41) no relation between defaecation frequency asked by questionnaire and CRC-incidence was found in males (BauschGoldbohm, unpublished results). The validiry of asking for defaecation frequency was tested in our Ca-restriction study: the Spearman correlation coefficient between asked and registered defaecation frequency was 0.84 $(P<0.01)$. In the studies of chapter 4 and 7 , defaecation frequency was higher in man than in women. Would defaecation frequency play a role in CRC risk of women?

In our study with habitual omnivores and vegetarians (chapter 4) 35 of the variance in defaecation frequency was explained by sex and the intake of dietary fibre, especially fibre from fruits and vegetables. In the Ca-restriction study, 26 of the variance was explained by sex and the intake of dietary fibre. 
Faecal $\mathrm{pH}$ was lowered by a vegan dier (chapter 3). Thirty percent of the variance in faecal $\mathrm{pH}$ was explained by the intake of $\mathrm{Ca}$ (chapter 4 ). A higher explanation was obtained when the Ca-concentration in faeces and the concentration of one of the main short chain fatty acids (SCFA), butyrate, in faecal water was put into the regression equation $\left(r^{2}=0.47\right)$ : a lower concentration of $\mathrm{Ca}$ and a higher concentration of butyrate lead to a lower $\mathrm{pH}$. A significant positive correlation between $\mathrm{Ca}$ in faeces and faecal pH was also found in the Ca-restriction study (chapter 7): $r=0.45$. Moreover in that study, a high $\mathrm{pH}$ of faecal water was correlated with a low cytotoxicity of faecal water (Spearman correlation coefficient $=-0.63, p<0.01$ ). The cytotoxicity of faecal water for erythrocytes was highly correlated with that for cells derived from a human colon adenocarcinoma cell line (42) and with hyperproliferation of colonic cells of rats (43). The positive correlation between $\mathrm{Ca}$-intake and faecal $\mathrm{pH}$ has been explained by the increase in faecal phosphate after Ca-supplementation, which may increase the buffer capacity of faeces (16).

Earlier studies have reported that faecal $\mathrm{pH}$ is higher in parients with $\mathrm{CRC}$ than in controls (chapter 1). However a more recent study showed no difference for age matched groups (44). They found higher faecal $\mathrm{pH}$ 's in older subjects. Also no difference was found in a case-control study measuring gastrointestinal $\mathrm{pH}$ by a $\mathrm{pH}$ sensitive radiotelemetry capsule (45).

In literature (17) a positive association between $\mathrm{pH}$ and percentage solubilized BA has been suggested. We did not find such a relation in our studies (chapter 4 and 7). We propose a CRC protecting effect of a high faecal $\mathrm{pH}$ : at a higher $\mathrm{pH}$ the secondary BA and the LCFA are more dissociated and therefore less hydrophobic. Both compounds were more cytolytic when their hydrophobicity increased (42).

\subsection{Calcium and magnesium in faecal water}

In our study in animals and humans with dietary Ca-binders (chapter 5 and 6), binding of dietary $\mathrm{Ca}$ by $\mathrm{Calcisorb}^{(\mathcal{B}}$ leads to lower concentrations of $\mathrm{Ca}$ and $\mathrm{Mg}$ in caecal and faecal water respectively. The concentration of $\mathrm{Ca}$ or $\mathrm{Mg}$ in faecal water may be related to CRC-risk $(46,47)$. Both ions have a direct inhibitory effect on colonic cell proliferation. The concentration of $\mathrm{Ca}$ in faecal water was not lowered on the Ca-restricted diet (chapter 7). Lapré et al (30) found higher concentrations of $\mathrm{Ca}$ in faecal water after supplementa- 
tion with Ca-carbonate from 1200 to about $3000 \mathrm{mg} /$ day, but Govers et al (16) found no significant increase after supplementation with $\mathrm{Ca}$ from milk products from 800 to about $1800 \mathrm{mg} / \mathrm{day}$.

No epidemiological or animal studies have been performed on the CRC risk of low concentrations of $\mathrm{Ca}$ and $\mathrm{Mg}$ in faecal water.

\subsection{Long chain fatty acids in faecal water}

The concentrations of LCFA in faccal water were not influenced in animals and humans by a lower availability of $\mathrm{Ca}$ and $\mathrm{Mg}$ (chapter 5 and 6 . On the other hand, faecal excretion values of LCFA were lower after binding $\mathrm{Ca}$ and $\mathrm{Mg}$. The hypothesis of Newmark (28) that a diet high in $\mathrm{Ca}$ and $\mathrm{Mg}$ lowers CRC risk by making LCFA less water-soluble, may be only valid for Ca at high intakes of saturated fat, which lead to high faecal concentrations of LCFA as in the studies of Lapré and Govers, where the intake of saturated fat was $120 \mathrm{~g} /$ day, while the intake in our human study was only $85 \mathrm{~g} / \mathrm{day}$.

The Ca-restricted diet of hypercalciuria type II patients does lower the concentration of LCFA in faecal water and also the cytotoxicity of faecal water (chapter 7). The concentration of LCFA in faecal water was highly correlated with the cytotoxicity of faecal water for erythrocytes $(\mathrm{r}=0.74)$. Moreover the correlation between changes in both variables was 0.60 .

The relation between faecal LCFA and CRC-risk has not been reported after the study of Sperry et al (48). They are suspected of increasing CRC because like $B A$, they activate protein kinase $C$ directly or through the activation of phospholipase D (49).

\subsection{Dietary treatment of urolithiasis patients}

Risk factors for Ca-oxalate stones are the enhanced excretion of oxalate, $\mathrm{Ca}$, urate, the decreased excretion of the inhibitors citrate and $\mathrm{Mg}$ as well as low urinary volume. The excretion of oxalate is the most important risk factor $(50)$.

From our intervention study it appears that a diet restricted in Ca to 500 $\mathrm{mg} / \mathrm{day}$ has a small benefit for hypercalciuric urolithiasis patients, because it 
lowers the excretion of oxalate, most problaby due to the lower content of protein and carbohydrates of this diet. This also lowered the concentration of BA and LCFA in faecal water and its cytoxicity.

The expected lowering of the Ca-excretion in urine by the Ca-restricted diet occured slightly and only in men. The reasons for this effect may be:

1. Women react in a different way from men on Ca-restriction. Studies reported in literature on the effects of a $\mathrm{Ca}$-restricted diet on Ca-excretion have been performed mainly in men (chapter 7)

2. The lowering effect reported in literature was measured after $\mathbf{4}$ days, while only after 10 days of Ca-restriction the concentration of calcitriol in serum will increase (51) and this will increase the Ca-excretion with urine (52)

3. Not all patients in our intervention study were true hypercalciuria type II parients because their diagnosis was based on a Ca-excretion $>5$ $\mathrm{mmol} /$ day and a lowered Ca-excretion after a diet restricted in $\mathrm{Ca}$, sodium and oxalate. Some may be more sensitive for the effect of sodium on Ca-excretion (53), others may be normal calciuretic and respond too slightly on a Ca-restriction to $400 \mathrm{mg} / \mathrm{day}$ (54). At our Dept. of Clinical Chemistry, normal values of urinary Ca-excretion are $1.4-7.5 \mathrm{mmol} / \mathrm{day}$.

Therefore the following scheme (see Figure 1) for diagnosis and dietary treatment of patients with Ca-oxalate stones should be studied for its effectivity and feasibility. Firstly, stone composition should be analyzed preferentially by IR-spectroscopy or X-ray diffractrometry to distinguish the different kinds of stones (55). Patients with a primary $\mathrm{Ca}$-oxalate stone are screened in the following way:

1. Medical history including medications, clinical chemical analysis of $24 \mathrm{~h}$ urine for volume, creatinine, urate, oxalate, glyoxylate, citrate,urea, $\mathrm{Na}$, $\mathrm{K}, \mathrm{Mg}$, fasting urine for $\mathrm{pH}$ and fasting serum for $\mathrm{Ca}$, phosphate, parathyroid hormone 1-84, a dietary anamnesis and antropometric datal on height and body weight. A pyelogram is made to detect anatomical abnormalities.

2. Creatinine excretion lower than $20 \mathrm{mg} / \mathrm{kg}$ body weight means wrong sampling of $24 \mathrm{~h}$ urine (56). A new sample of $24 \mathrm{~h}$ urine has to be collected.

3. Hyperuricosuria ( $>450 \mathrm{umol} / \mathrm{d}$ ) and urinary $\mathrm{pH}<5.5$ in the absence of excessive intestinal alkali loss or animal protein intake, will be caused by gouty diachesis. The concentration of uric acid in serum will also be increased (57). If $\mathrm{pH}$ is normal, the uricosuria maybe due to a high intake of meat or fish products, beer or coffee (58). These dietary habits can be detected from the dietary and urinary data: urea-excretion $>250 \mathrm{mmol} / \mathrm{d}$ 


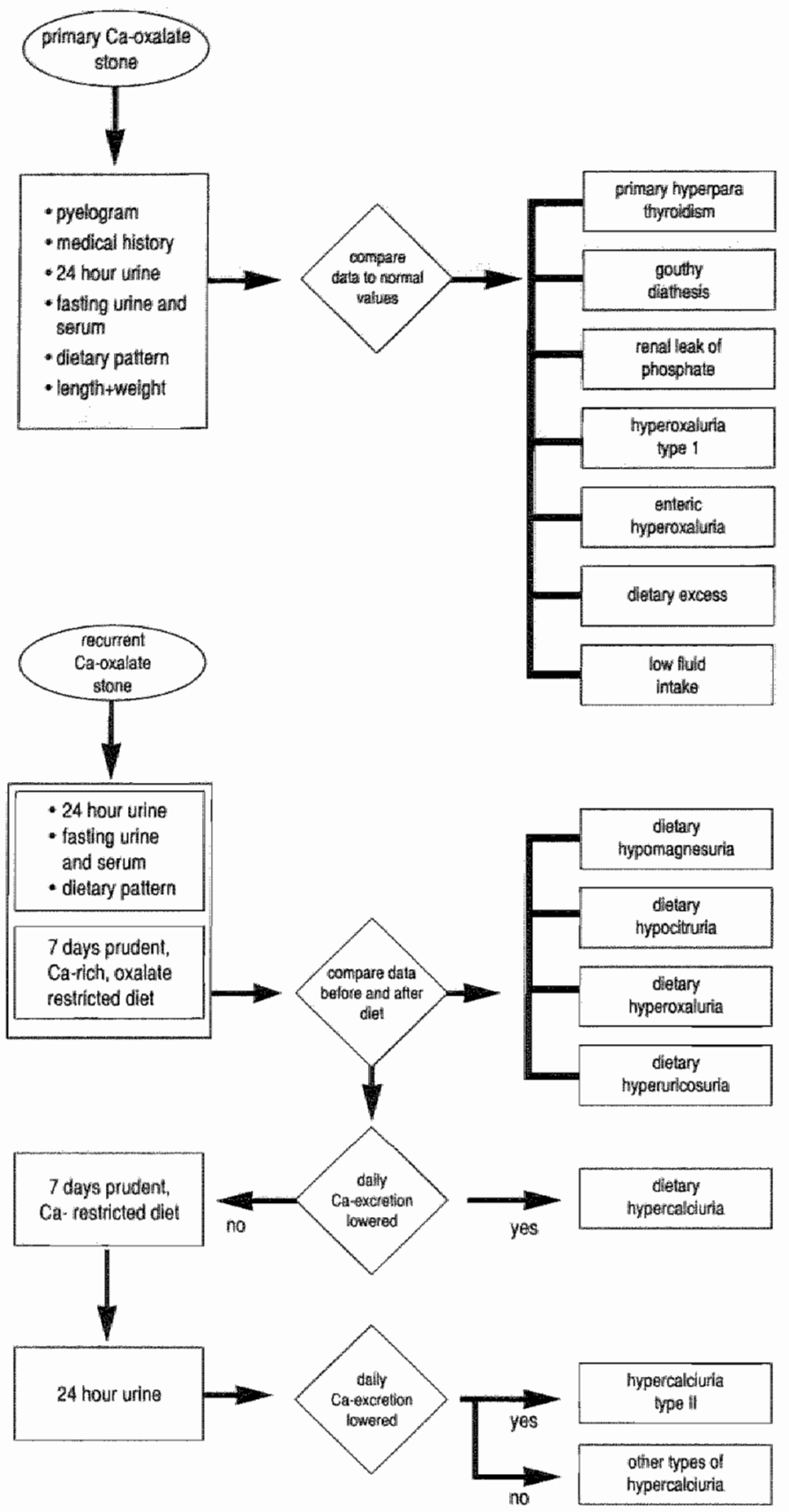

FIGURE 1

Proposed metabolic screning of Ca-oxalare stone patients 
means an intake of animal protein higher than $50 \mathrm{~g} /$ day $(\mathrm{S}$. Houterman, personal communication). A prudent diet (see below), restricted a.o. in animal protein will be the dietary therapy. With gouty diathesis or if the diet is inadequate, allopurinol or potassium citrate should be given.

4. Hyperoxaluria ( $>450 \mathrm{umol} / \mathrm{d}$ ) with a high concentration of urinary glyoxylate means a pyridoxine deficiency (primary hyperoxaluria type I). These patients should be treated with pyridoxine and if not effective with cirrate (59). Other hyperoxalurias may be caused by bowel disturbances (60) or a high intake of animal protein or oxalate-rich products. Bowel disturbances should be treated with Ca-supplementation $(1.5 \mathrm{~g} / \mathrm{d})$ and a diet with minimal amounts of oxalate. The other hyperoxalurias can be corrected by dietary measures.

5. Hypocitraturia (citrate $<2.1 \mathrm{mmol} / \mathrm{d}$ ) may be due to a high intake of animal protein or salt (61). The therapy should be a prudent diet (see below).

6. Hypercalciuria ( $\mathrm{Ca}>5 \mathrm{mmol} / \mathrm{d}$ ) (57) with serum phosphate $>0.8 \mathrm{mmol} / \mathrm{l}$ means a renal leak of phosphate. Orthophosphate is the therapy. If serum $\mathrm{Ca}>2.6 \mathrm{mmol} / \mathrm{l}$ and serum parathryroid hormone $1-84>58 \mathrm{pg} / \mathrm{ml}$ the diagnosis is primary hyperparathyroidism. They can be treated with parathyroid surgery.

The other types of hypercalciuria should be checked by their dietary intake of protein, $\mathrm{Na}, \mathrm{K}, \mathrm{Ca}$, carbohydrates, mono- and dissacharides, oxalate-rich products, energy, fluid and Mg-rich products (62). The data on dietary intake of the first 4 components can be confirmed by urinary data on urea, $\mathrm{Na}, \mathrm{K}$, $\mathrm{Ca}$, while the intake of fluid must correlate with the amount of daily urine. A high intake of carbohydrates, mono- and dissacharides and energy may be reflected in a body mass index $>25$. If there are large deviations from normal values and/or eating pattern shows large meals in the evening (63), a prudent diet (see below) equally spread over the day with a high intake of fluid $(>2,5$ I urine per day, ) are prescribed. The patients can control their intake of fluid by measuring the specific gravity of urine $(<0.012 \mathrm{~g} / \mathrm{l})$ by dip-sticks $(64,65)$.

Recurrent stone patients (a stone within an interval of $2 \mathrm{yrs}$ ), patients with stones in both kidneys and patients of age $<18$ yrs should be studied for the causes of their hypercalciuria, hyperoxaluria, hyperuricosuria, hypocitraturia and/or hypomagnesuria on a Ca-rich and if necessary on a Ca-low diet $(66,67)$ :

1. They consume during one week a constant, prudent diet: $30 \mathrm{~g}$ animal protein, $1000 \mathrm{mg} \mathrm{K}, 3100 \mathrm{mg} \mathrm{Na}, 120 \mathrm{~g}$ mono- and disaccharides, 30 energy of fat, $300 \mathrm{mg} \mathrm{Mg}$, at least $1.5 \rrbracket$ fluid, no more than 4 glasses of beer, no more than 3 cups of coffee/day. Moreover, this experimental diet should contain no oxalate-rich products like spinach or whubarb. The 
Ca-content of the diet will be about $400 \mathrm{mg}$. The compliance to the diet can be derived from data on urinary urea, $\mathrm{K}$ and $\mathrm{Na}$. The other amount of $\mathrm{Ca}(600 \mathrm{mg})$ is standardized and can be checked by giving $\mathrm{Ca}$ gluconate-tablets ( 6 per day) and counting pills that are not used. Comparing data of $24 \mathrm{~h}$ urine before and after this week for urea, $\mathrm{Ca}, \mathrm{Na}, \mathrm{K}$, phosphare, uric acid, $\mathrm{Mg}$, oxalate and citrate will detect a dietary origin of these abnormalities. They can be treated with a prudent diet, that is palatable and also active against other chronic diseases like cardiovascular diseases and several forms of cancer.

2. Patients who show no decrease in Ca-excretion on the diet mentioned in 1., should consume the constant, prudent dier for one week containing only the basal $400 \mathrm{mg}$ Ca. If normalization of Ca occurs, while the urinary excretions of $\mathrm{Na}, \mathrm{Mg}, \mathrm{K}$ and urea are constant, these patients have an hyperabsorption of dietary $\mathrm{Ca}$ and should be treated with a $\mathrm{Ca}$ - and oxalate-restricted diet (hypercalciuria type II). Further research is needed to form a group of patients that is at high risk for osteopenia on this diet.

3. Patients whose Ca-excrerion does not respond to the Ca-restricted diet should be treated with thiazide + K-citrate + Na-restricted diet (150 $\mathrm{mmol} / \mathrm{d}$ ) and high fluid intake divided over day and night. Further research is needed to split these patients into groups in which mainly the bones, the kidney or the intestine are involved.

\section{Conclusions}

Based on the results of the studies described in this thesis and on the literature described and discussed above, the model for the role of faecal constituents in the parhogenesis of CRC have to be adapted (Figure 2). The faecal constituents influence the proliferation of colonic epithelial cells. Increased cell proliferation is associated with a higher expression of mutations.

The in lluences of several dietary factors on the faecal constituents are shown.

Meat and meatproducts are rich in saturated fat, while eggs are rich in cholesterol. Both are supportive for higher concentrations of BA and LCFA in faeces and faecal water. Vegetables and grains are rich in dietary fibre and resistant starch, leading to a higher faecal bulk and a lower faecal $\mathrm{pH}$. A high faecal bulk diminishes the concentration of BA and LCFA in faeces and faecal water. Dietary fibre and resistant starch will diminish faecal $\mathrm{pH}$ by increasing the butyrate production in the colon. A low $\mathrm{pH}$ will increase the amount of LCFA and undissociared BA in the colonic contents, which will increase the hyperproliferation of epithelial cells. However, buryrate will lower this hyper- 


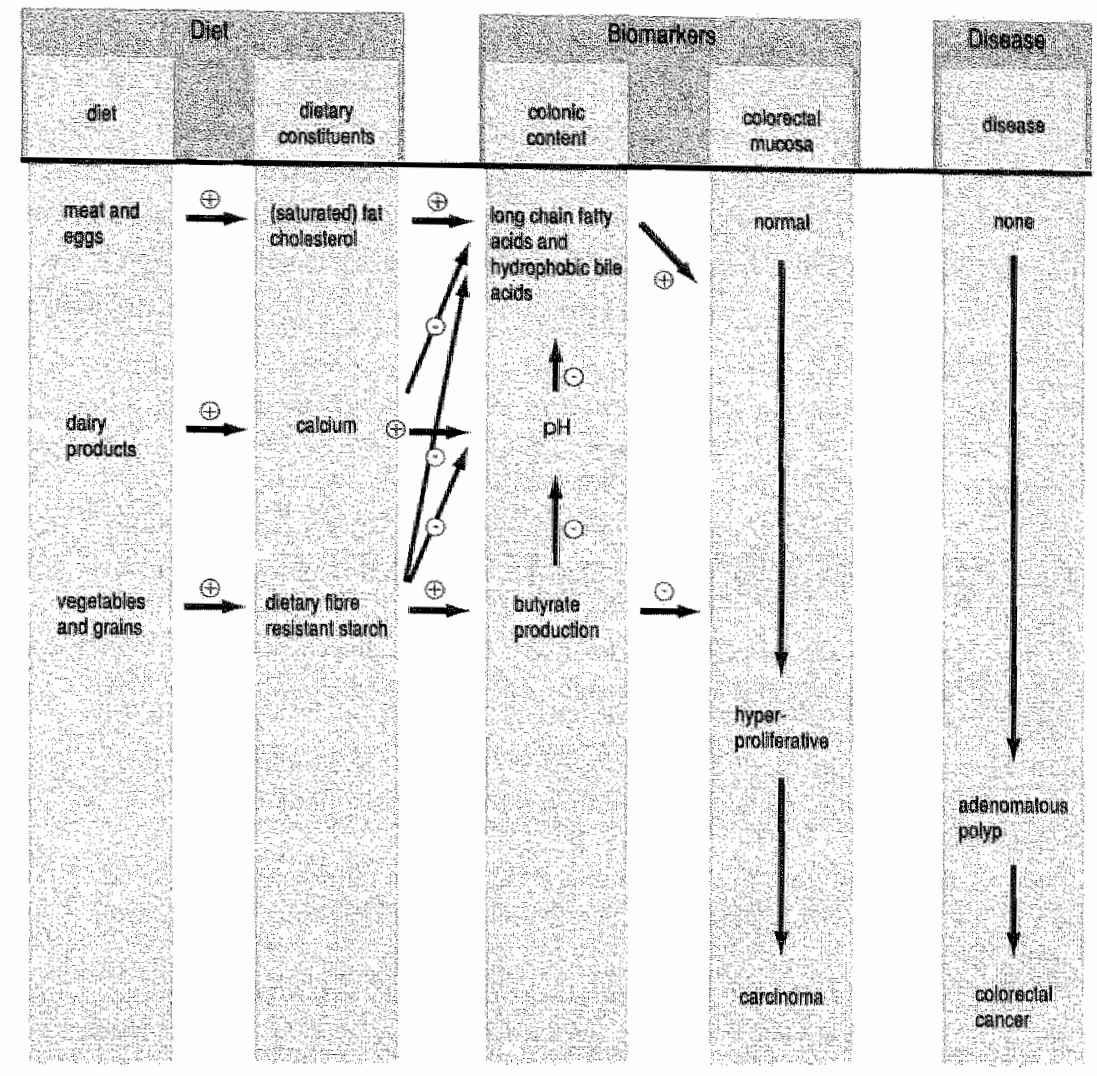

\section{FIGURE 2}

Proposed model for the role of diet and facal markers in colorectal carcinogenesis

proliferation. Dietary Ca above $1000 \mathrm{mg} /$ day may decrease the amount of solubilized BA and LCFA and the ratio hydrophobic to hydrophilic BA in faecall water.

A diet rich in dietary fibre and resistant starch and restricted in saturated fat may diminish the risk for CRC. Vegan diets may protect against CRC, in spite of their resulting low faecal $\mathrm{pH}$, due to their low content of saturated fat and their high dietary fibre content. Lacto-ovo-vegetarian diets which may not be that high in dietary fibre, may be protective because of their lower amount of saturated fat and and their higher amount of $C$ a than the vegan and the omnivorous diet. A prudent diet which is rich in dietary fibre from grains and fruits and vegetables, sufficient in milkproducts and fluids and moderate in meat, eggs, sugar and table salt may exert a similar protective effect ats the vegetarian diets. 
A diet restricted in $\mathrm{Ca}$ in which the omitted milkproducts are not substituted by products rich in animal protein like meat and eggs, may be of a small benefit for male urolithiasis parients generically predisposed to $\mathrm{Ca}$-oxalate stones, without increasing the risk of CRC. However in such women, that diet may be ineffective and may even raise the risk of osteoporosis. A prudent diet as described by the Dutch guidelines for a healthy diet (see above), should fulfill all requirements at the same time with regard to the risk of urolithiasis, osteoporosis and CRC.

\section{References}

1. Fearon, E.R., Vogelstein, B. A genetic model for colorectal carcinogenesis. Cell 61 (1990) $759-767$

2. Reddy, B.S. Engle, A. Simi,B., Goldman, M. Effect of dierary fiber on colonic bacterial enzymes and bille acids in relation to colon cancer. Gastroenterology 102 (1992) 1475 1482

3. Morotomi, M., Guillem, I.G., LoGerfo, P., Weinstein, I.B. Production of diacylglycerol, an acrivator of protein kinase $\mathrm{C}$, by human intestinal microflora. Cancer Res. 50 (1990) $3595-3599$

4. Clausen, M.R., Bonnen, H., Mortenser, P. B. Colonic fermentation of dietary fibre to sthort chain fatry acids in parients with adenomatous polyps and colonic cancer. Gun 32 (1991) 923-928

5. De Kok T.M.C.M., Levels,P.J, Faassen, A. van, Hoor, F, ten, Kleinjans, J.C.S. Chromatographic methods for the determination of toxicants in faeces. J. Chromatography 580 (1992) $135-159$

6. Srellatd, F. Kalek, H.D., Kruis, W., Paumgartner, G. Dereminacion of increased bile acid excretion by derermination of bile acid content in a single stool sample. Clinica Chimica Acra $140(1984) 85-90$

7. Miettinen, T.A. Gas-liquid chromatographic determination of fecal neutral sterols using a capillary column. Clin. Chim.Acra 124 (1982) 245-248

8. Glatz, J.F.C., Schouten, F.J.M., Den Engelsman, G., Katan, M.B. Quantitative determination of neutral steroids and bile acids in human feces by capillary gas-liquid chromatography. In: Cholesterol metabolism in health and discase: studies in the Netherlands. A.C. Beynen, M.J.H. Geelen, M.B. Katan, J.A. Schouten (ed), Wageningen, Ponsen\&Looijen, 1985, p. 103-112

9. Katan, M.B., Beynen, A.C., De Vries, J.H.M. Nobels, A. Existence of consistent hypoand hyperesponders no dietary cholesterol in man. Am. I. Epidemiol. 123 (1986) 221 234

10. Sheltawy, M.J., Lososwsky, M.S. Detemination of faecal bile acids by an enzymatic method. Clin, Chim.Acta 64 (1975) 127-132

11. Child, P., Aloe, M., Mee, D. Separation and quantiation of fatry acids, sterols and bile acids in feces by gas chromatography as the butyl eser-acetate derivatives. J. Chromarogr. $415(1987) 13-26$

12. Guldutuna, S., You, T., Kurts, W, Leuschner, U. High performance liquid chromatographic determination of free and conjugated bille acids in serum, liver biopsies, bile, gastric juice and feces by fluorescence labeling. Clin.Chim. Acra 214 (1993) 195-207 
13. Faassen, A. van. Dokkum, W. van, Pikaar, N.A., Hermus, RJ.J. The influence of a lacrovegetarian, a vegan and a mixed diet on colonic funcion of man: preliminary results. In: Liver, nutrition, and bile acids. Galli, G., Bosisio, E. (eds), New York, Plenum Press, 1985, p. $249-252$

14. Meer $\mathrm{R}$, van der, Veies, H. T. de. Differential binding of glycine- and caurine-conjugated bile acids ro insoluble calcium phosphate. Brochem. J. 229 (1985) 265-268

115. Lupton, J.R, Chen, X.-Q.Frolich, W., Schoefter, G.L. Peterson, M.L. Rars fed high fat diers with increased calcium lewels have fecal bile acid concentracions similar to those of rats fed a low far dier. J. Nurr. 124 (1994) 188-195

16. Govers, M.J.A.F., Termont, D.S.M.L.. Lapre, J.A., Kleibenker, J.H., Vonk, R.J., van der Meer, R. Calcium in dairy products precipitates intestinal surfactanrs and decneased cytolytic acrivity of fecal water in healthy subjects. In: Govers. M.J.A.P. Dierary calcium and phosphate in the prevention of colorectal cancer. Thesis University of Groningen, Groningen, $1993, \mathrm{p} .115-135$

17. Munster, L.P. wan, Tangerman, A., Nagengast, F.M. Effect of resistant starch on colonic fermentation, bile acid metabolism, and mucosal proliferation. Dig. Dis.Sci. 39 (1994) 834.842

18. Bartram, H.-P., Scheppach, W, Heid, C., Fabian, C., Kasper, H. Efect of sarch malabsorption on fecal bile acids and neutral sterols in humans: possible implicarions for colonic carcinogenesis. Cancer Res. 51 (1991) 4238-4242

19. Cummings, J.H., Bingham, S.A., Heaton, K.W., Eastwood, M.A. Fecal weight, colon cancer risk, and dietary intake of nonsarch polysacharides (dictary fiber). Caastroenterology $103(1992) 1783-1789$

20. Howe, G.R., Benito, E., Castellero, R., Corne, J., Estewe, J, Gallagher, R.P. and several others. Dietary intake of fiber and decreased risk of eancers of the colon and recturm: evidence from the combined analysis of 13 case-controll studies. J. Natl. Cancer Inst. 84 (1982) $1887-1896$

21. Bidoli, E. Franceschi, S., Talamini, R., Barra, 5., La Vecchia C. Food consumption and cancer of the colon and recum in north east Italy. Int. J. Cancer 50 (1992) 223-229

22. Potter, J.D., Slattery, M.L., Bostick, R.M., Gapstur, S.M. Colon cancet: a review of the epidemiology. Epidemiol. Rev. 15 (1993) $499-545$

23. Giovannucci, E., Rimm, E.B., Stampfer, M.J., Colditz, G.A., Ascherio, A., Willett, W. Intake of fat, meat, and fiber in relation to risk of colon cancer in men. Cancer Res. 54 (1994) 2390-2397

24. Willert, W.C., Stampfer, M.J., Colditz, G., Rasner, B.A., Speizer, F.E. Relation of meat, fat, and fiber intake to the risk of colon cancer in a prospecrive study among women. New Engl. J. Med. $323(1990) 1664-1672$

25. Cats, A. Keibeuker, J.H., Kuipers, F., Hardonk, M.J., Verschueren, R, C., Boersma, W., Vonk, R.J., Sluiter, W.I. Mulder, N.H., Wolnhers, B.G., de Vries, E.C.E. Changes in rectal epithelial cell proliferation and intestinal bile acids after subtotal colectomy in familial adenomatous polyposts. Cancer Res. 52 (1992) $3552-3557$

26. Meer, R. wan der, Welberg, J.W.M., Kuipers, E, Klcibeuker, JH., Mulder, N.H., Termont, D.S.M.L., Vonk, R.J., Vries, H.T. de, Vries, E.G.E. de Effect of supplementat dietary calcium on the intestinal association of calciun, phosphate and bile acids. Gastroenterology 99(1990) 1653-1659

27. Newmatk, H.L., Wargovich. M.J.,Bruce, W.R. Colon cancer and dicary far, phosphate. and calcium: a hypothesis. J. Natl .Cancer Inst. $72(1984) 1323-1325$

28. Pence, B,C. Buddingh, F. Inhibition of dierary fat-promoted colon catreinogenesis in rats by supplemental calcium or viramin $\mathrm{D}_{3}$. Carcinogenesis 9 (1988, 187-190 


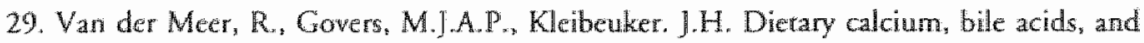
colon cancer. In: Bile acids in gastroenterology. Basic and clinical advances. Hofmann. A.F., Paumgarmer, G, Stich, A. (ed), Dordrecht, Kluwer Academic Press, 1995, p. $302-311$

30. Lapre, J.A., de Vries, H.T. Termont, D.S.M.L., Kleibeuker, J.H., de Vries, E.G.E. van der Meer, R. Mechanism of the protective effecr of supplemental dietary calcium on cytolyric acrivity of fecal water. Cancer Res. 53 (1993) 248-253

31. Alder, R. I. Mckeown-Eyssen, G. Bright-See, E. Randomized trial of the effect of calcium supplementation on fecal risk factors for colorectal cancer. Am.J. Epidemiol. 138 (1993) $804-814$

32. Imray, C.H.E., Radley, S., Davis, A., Barker, G., Hendrickse.C.W., Donovan, I.A., Lawson, A.M., Baker, P.R., Neoptolemos, J.P. Faecal unconjugated bile acids in patients. with colorectal cancer or polyps. Gut 33 (1992) 1239-1245

33. Winaver, S.J., Zauber, A.G., Ho, M.N.,O'Brien, M.J., Gottieb, L.S., Stemberg, S.S. et al. Prevention of colorectal cancer by colonoscopic polypectomy. N. Engl. J. Med. 329 (1993) $1977-1981$

34. McKeown-Eyssen,G., Bright-See, E., Bruce, W.R., Jazmalyi, W. and the Toronto Polyp Prevention Group. A randomized trial of a low fat high fibre dict in the recurrence of colorecral polyps. ]. Clin. Epidemiol. 47 (1994) 525-536

35. Latta, R.K., Fiander, H., Ross, N.W., Simpson, C., Schneider, H. Toxicity of bile acids to collon carncer cell lines. Cancer Lett. 70 (1993) $167-173$

36. Rafter, J.J., Branting, C. Bile acids - interaction with the intestinal mucosa. Eur. J. Cancer Prew. $1(1991) 49-54$

37. Craven, P.A., Pfanstiel, J., DeRubertis, F.R. Role of activation of protein kinase C in the stimulation of colonic epithelial proliferation and reactive oxygen formarion by bile acids. J. Clin. Invest. 79 (1987) 532-541

38. Steinmet\%, K.A., Porter, J.D. Egg consumption and cancer of the collon and rectum., Eur. J. Cancer Prev. 3 (1994) 237-245

39. Lang, N.P., Butler, M.A., Massengill, I., Lawson, M.., Stotu, R. C., Hauer-Jensen, M., Kadlubar, F.F. Rapid metabolic phenotypes for acetyluranserase and cytochrome P4501A2 and putarive exposure to food borne hererocyclic amines increase the risk for colorectal cancer or polyps. Cancer Epidemiol. Biomarkers \& Prev. 3 (1994) 675-682.

40. Oh, S.Y., Monaco, P.A. Effect of dietary cholesterol and degrea of fat unsaturation on plasma lipid level lipoprotein composition, and fecal steroid excretion in normal young adule men. Am. J. Clin. Nurr. 42 (1985) 399-413

41. Brandt, P.A. van den, Goldboltm, R.A., Veer, P. van 't, Wolovica, A., Hermus, R. J., Sturmans, F.. A large-scale prospectiwe chohort study on diet and cancer in the Netherlands. J Clin Epidemiol 43 (1990) $285-295$

42. Lapré, J.A., Termont, D.S.L.M., Groen, A.K., Van der Meer, R. Lytic effects of mined micelles of fatry acids and bile acids. Am.. P. Phsiol. 263 (1992) G333-G337

43. Lape, J.A., De Vries, H.T., Koeman, J.H., Van der Meer, R. The antiproliferative effect of dictary calcium on colonic epirhelium is mediated by luminal surfactants and dependent on the type of dietary fac. Cancer Res. 53 (1993) 784.789

44. Hove, H., Rye Clatusen, M.R., Mortensen, P.B. Lactace and $\mathrm{pH}$ in faeces from pacients with colonic addenomas or cancer. Gut 34 (1993) 625-629

45. Pye, G., Evans, D.F, Ledingham, S., Hardcastle, J.D.. Gastrointestinal intraluminal pH in normal subjects and those with colorectal adenoma or carcinoma. Gut 31 (1990) $1355-1357$ 
46. Buset, M., Lipkin, M., Winawer, S., Swaroop, S., Friedman, E. Inhibition of human colonic epithelial cell proliferation in vivo and in witro by calcium. Cancer Res. 46 (1986) $5426-5430$

47. Wang, A., Yoshimi, N., Tanaka, T., Mori, H. The inhibitory effect of magnesium hydroxide on the bile acid-induced cell proliferation of colon epichelum in tats with comparison to the action of calcium lactate Carcinogenesis 15 (1994) 2661-2663

48. Sperry, J.F., Salyers,A.A., Wilkins, T.D., Fecal long chain fatty acids and colon cancer risk. Lipids $11(1976) 637-639$

50. Awad, A.B., Basilious, B.G., Finks, C.S., Horvarh, P.J. In witro acrivity and inhibition of rar colonic phospholipase D by farty acids. Cancer Lerr. 86 (1994) $105-109$

51. Scharrel, O. , Hesse, A. Die Bedeurung der Ernahrung in der Therapie des Harnsteinleidens. Teil 1: Kalziumoxalat- und Hamsauresteine. Ernahrungs-Umschau 4l (1994) $377-381$

52. Broadus, A.E., Insogna , K.L., Lang, R., Ellison, A.F. and Dreyer, B.E. Evidence for disordered control of 1,25 dihydroxyvitamin $D$ production in absorptive hypercalciurias. N. Engl. J. Med.311:(1984) 73-80

53. Hess, B. Diagnostische Marker bei Kalzium-Nephrolithisis - Newes und Althergebrauchres in neuem Gewand. Schweiz. Med. Wochenschr. $125(1995) 2660-2470$

54. Burtis, W.J., Gay, L., Insogna, K.L., Ellison, A. Broadus, A. Diecary hypercalciuria in patients with calcium oxalate kidney stones. Am. J. Clin. Nucr. 60 (1994) 424-429

55. Batalle, P., Achard, J.M., Fournier, A., Bondailliez, B., Wested, P.F., Esper, N.E. et al. Diet, vitamin $D$ and vercebral mineral densicy in hypercalciuric calcium stone formers. Kidney Intern. 39 (1991) 1193-1205

56. Daudon, M., Bader, C.A., Jungers, P. Urinary calculi: review of classification merhods and correlations with etiology. Scanning Microscopy 7 (1993) $1081-1106$

57. Pak, C.Y.C.: General guidelines in medical evaluation. In: Urolithiasis: a medical and surgical reference. M.I. Resnick and C.Y.C. Pak (eds), Philadelphia, W.B. Saunders Company, 1990, p 153-171.

58. Levy, F.L., Adams-Huer, B., Pak, C.Y.C. Ambulatory evaluation of nephrolithiasis: an update of a 1980 protocol. Am. J. Med. 98 (1995) 51-59

59. Scharrel, O., Hesse, A. Die Bedeutung der Ernahrung in der Therapie des Harnsteinleidens. Teil 2: Phosphat-, Zystin- und seltene Steine. Ernahrungs-Unschau 42 (1995) $127-131$

60. Preminger,G.M. Renal calculi: parhogenesis, diagnosis, and medical rherapy. Sem. Nephrol.12 (1992) 200-216

61. Hoppe, B., Neuhaus, T., Blau, N., Leusman, E. Efracy of oral cirtate administration in primary hyperoxaluria. In: Abstracts Sixth Europeat Symposium on Urolithiasis, Stocks. holm, 1995, p. 169

62. Kok, D.J., Lestra, J.A., Doorenbos, C.J. Papapoulos, "S. F. "The effects of dictary excesses in animal protein and in sodium on the composition and the crystallization kinetics of calcium oxalate monohydrate in urines of healthy men. J. Clin. Endocrinol. Mecabol. 71 (1990) $861-867$

63. Coe, F.L. Parks. J.H. Idiopathic hypercalcurat the contribution of dr. Jacob Lemann, Jr. J. Am. Soc. Nephrol. 5 (1.994) 559-\$69

64. Smith, L.H. Dietary management of urolithiasis. Curr. Opin. Nephrol. Hypert. 3 (1994) $189-194$

65. MoCormack, M., Dessureault, J., Guitard, M. The urine specific graviry dipstick: a useful tool to increase fluid intake in stone forming patients. J. Urol. 146 (1991) $1475-1477$ 
66. Hennequin, C., Daudon, M., Phung, T. Lacour, B., Jungers, P. Urine specific graviry $(\mathrm{sg})$ and risk of crystalluria: influence of $\mathrm{pH}$ on test strips. In: Abstracts Sixth European Symposium on Urolithiasis, Stockholm, 1995, p. 131

67. Peacock, M., Hodgkinson, A., Nordin, B.E.C. Importance of dietary calcium in the definition of hypercalciuria. Brit. Med. J. 3 (1967) 469 -471

68. Anonymus. Use of high normal calcium intake in screening for hypercalciuria. In: Handbook of clinical dietetics. Am. Dieteric Ass., 2nd ed., New Haven, Yale University Press, 1992, p. 522 


\section{Samenvatting}

De invloed van verschillende voedingen op kenmerken van de ontlasting die samenhangen met het risico op dikke darmkanker. Onderzoek met vegetariers en niersteenpatiënten.

Dikke darmkanker (colon- en rectumkanker) is de op cén na meest woorkomende vorm van kanker bij vrouwen en de op twee na meest voorkomende bij mannen in de meeste Westerse landen. De behandeling d.m.v. operatie, medicijnen en/of bestraling kan slechts bereiken dat 5 jaar na behandeling nog $50 \%$ van de pariènten in leven is. Daarom is het gewerrst ook aandacht re schenken aan de preventie van dikke darmkanker.

Het lijkt erop dat her vóórkomen van dikke darmkanker beinvloed wordt door omgevingsfactoren, 0.a. voedingsgewoonten. Het risico is ook genetisch bepaald, maar groepen mensen mer voedings- en andere leefgewoonten die sterk verschillen van de gemiddelde bevolking zoals Zevende dags adventisten. Mormonen en vegetariers, hebben een lagere sterfte tengevolge van dikke darmkanker.

Onderzoek naar het ontstaan van dikke darmkanker heeft laten zien, dat deze ziekre ontstaat door veranderingen in delen van het DNA die betrokken zijn bij de vorming van kanker. De tijd tussen de eerste verandering en het optreden van de ziekre is tenminste 20 jaar. Daarom is er gezocht naar biologische kenmerken van dit risico die naar voren komen in die 20 jaar. Omdat de dikke darm in kontakt staat mer het bloed en met de darminhoud, zonden kenmerken van de omgevingsfactoren die dikke darmkanker veroorzaken, in deze delen van het lichaam te vindem moeten zijn. Resten van de darminhoud komen terecht in de ontlasting en onderzock van de ontlasting zal dan ook informatie moeten kunnen opleveren over risico's voor her ontstaan van dikke darmkanker.

In hoofdstuk 1 zijn de onderzoeksgegevens die beschreven zijn in de literatuur voor het begin van ons laatste onderzoek. (1990), samengevat. Op grond hiervan gingen we ervan uit dat een voeding met veet vlees, weinig voedingsvezel en weinig calcium samenhangt met een hoog risico op dikke darmkanker. Kenmerken van de ontlasting die hoogst waarschijnlijk samenhangen met het risico op dikke darm kanker en die weranderen onder invloed van voedingsgewoonten, zijn: 
- de hoeveelheid ontlasting per dag

- de concentraties van de secundaire galzuren deoxycholzuur en lithocholzuur en van vetzuren zoals stearinezuur in de gehele ontlasting en in het waterige deel van de ontlasting

- de zuurgraad van de ontlasting.

Het doel van de onderzoekingen in dit proefschrift was na te gaan of gebruikelijke voedingsgewoonten die verschillen in de dagelijkse hoeveelheid vlees, voedingsvezel en calcium, zoals een omnivore, een lacto-ovo-vegetarische en een veganistische voeding en het calcium-beperkte dieet van niersteenpatiënten, invloed hebben op de ontlastingskenmerken die samenhangen met het risico op dikke darmkanker. Als de effecten in dezelfde richting wijzen als de gegevens over de invloed van voedingsgewoonten op het risico voor dikke darmkanker, dan kunnen in epidemiologische onderzoekingen de biologische kenmerken gebruikt worden als factor ter voorspelling van het risico op ziekte en hoeft niet gewacht te worden tot zich een tumor ontwikkeld heeft. Als de gegevens over de ontlastingskenmerken passen bij een biologische verklaring voor de veronderstellingen over voeding als oorzaak van het ontstaan van dikke darmkanker, dan worden die veronderstellingen ondersteund.

Allereerst hebben we een nauwkeurige en juiste methode ontwikkeld voor de bepaling van de concentratie van de meest voorkomende galzuren in de menselijke ontlasting, deoxycholzuur en litocholzuur (hoofdstuk 2). Mer de hierop gebaseerde methoden die in onze verdere onderzoekingen werden gebruikt, zijn getallen voor beide galzuren werden verkregen die overeenkwamen met de resultaten uit andere laboratoria. Bovendien kunnen de in lagere hoeveelheden voorkomende galzuren zoals de $3 \beta$-isomeren van deoxy-en lithocholzuur en de 7 - en 12-keto-galzuren bepaald worden. Deoxy-, lithocholzuur en hun $3 \beta$-isomeren en de keto-verbindingen worden ook wel de secundaire galzuren genoemd, omdat ze gevormd worden door de bacterien in de dikke darm uit de de in de lever gevormde primaire galzuren cholzuur en chenodeoxycholzuur.

Hoofdstuk 3 beschrijft de resultaten van een streng gecontroleerd onderzoek met jonge, mannelijke vrijwilligers, die drie typen voedingen na elkaar gebruikten. Een lacro-ovo-vegetarische voeding (vegerarisch met melk en eieren) en een veganistische voeding (alleen plantaardige produkten) verlaagden de concentraties van deoxy-en lithocholzuur in de totale ontlasting en verhoogden de hoeveelheid ontlasting per dag en het aantal keren ontlasting per week. Deze effecten werden hoogst waarschijnlijk veroorzaakt door de grotere hoeveelheid voedingsvezel in vergelijking met de gemengde voeding 
(wlees, eieren,melk- en plantaardige produkten). De concentratie van de som van deoxy-en lithocholzuur in de totale ontlasting was hoger tijdens de lacto-ovo-vegetarische voeding dan tijdens de veganistische voeding. Dit werd in de discussie roegeschreven aan de grotere hoeveelheid calcium in de lactoovo-vegetarische voeding. De zuurgraad van de ontlasting was lager tijdens de veganistische voeding dan tijdens de twee andere voedingen.

Uit andere epidemiologische onderzoekingen komt vaak naar voren, dat een hogere inname van voedingsvezel gepaard gaat met een lager risico op dikke darmkanker. Groepen mensen met een dagelijkse hoeveelheid ontlasting van meer dan 200 gram hadden een 3 maal zo laag risico op dikke darmkanker. In een klein onderzoek bleek dat patiënten met adenomateuze poliepen in de dikke darm, een voorstadium van dikke darmkanker, hogere concentraties van de secundaire galzuren in de ontlasting hadden dan gezonde controles. Ook bleken patiënten met ontstekingen van de dikke darm die een hoge concentratie hadden van deoxycholzuur in de ontlasting, later meer kans te hebben een dikke darmtumor te ontwikkelen dan soortgelijke patiënten met een lage concentratie.

M.a.w. de concentratie wan secundaire galzuren in de ontlasting zou in epidemiologisch onderzoek gebruikt kunnen worden als factor ter voorspelling van het risico op dikke darmkanker. De betekenis van de hoeveelheid ontlasting per dag, het aantal keren ontlasting per week en de zuurgraad van de ontlasting moet nog nader onderzocht worden in prospectieve epidemiologische onderzoekingen alvorens ze te gebruiken als biologisch kenmerk van het risico op dikke darmkanker. Onze resultaten ondersteunen de veronderstelling dat een hogere inname van voedingsvezel beschermt tegen het ontstaan van dikke darmkanker.

In hoofdstuk 4 staan de resultaten beschreven van een onderzoek bij mannen en vrouwen tussen de 59 en 67 jaar die gedurende lange tijd gewoon waren een lacro-ovo-vegetarische voeding of een omnivore voeding (mengsel van vlees, eieren, melk en plantaardige produkten) te gebruiken. De lacto-ovo-vegetariers hadden geen lagere concentraties van galzuren in de totale ontlasting maar wel een lagere concentratie in het waterige deel wan do ondlasting. Dir deel wordt verkregen na centrifugatie op hoge snelheid en wordt verondersteld in kontakt te staan met de cellen van de darmwand. De hoeveelheid ontlasting per dag en her aantal keren ontlasting per week was hoger bij de vegetariers dan bij de omnivoren en hoger bij mannen dan bij wrouwen. De zuurgraad van de ontlasting verschilde niet tussen de omnivoren en de vegetariers. In hoofdstuk 8 is beschreven, dat dertig procent van de variatie in de concentratie van deoxycholzuur in het waterige deel van de ontlasting verklaard kon worden door de hoeveelheid verzadigd ver die per dag werd gegeten, terwijl $24 \%$ van de variatie verklaard kon worden uit de inname van 
cholesterol. Daarnaast kon nog twintig procent van deze variatie verklaard worden door geslacht en hoeveelheid ontlasting per dag. Ook kon twintig procent van de variatie in de hoeveelheid ontlasting per dag en het aantal keren ontlasting per week verklaard worden door de hoeveelheid voedingsvezel, vooral uit groente en fruit. De helft van de variatie in de zuurgraad kon verklaard worden door de concentratie van calcium in de ontlasting en de concentratie van één van de belangrijkste vluchtige vetzuren, boterzuur, in het waterige deel van de ontlasting.

Niet alle epidemiologische onderzoekingen laten zien dat de inname van verzadigd vet gepaard gaat met een verhoogd risico op dikke darmkanker. Maar het veel eten van voedingsmiddelen als rood vlees en eieren, hangt wel samen met een verhoogd risico. Het verband tussen de concentratie van secundaire galzuren in het waterige deel van de ontlasting en het risico voor dikke darmkanker, is nog niet onderzocht in grootschalige epidemiologische onderzoekingen.

Uit onderzoek door anderen was gebleken dat calcium-supplementatie de concentratie van galzuren in het waterige deel van de ontlasting kon verlagen. Bovendien hadden epidemiologische en experimentele onderzoekingen laten zilen, dat een hoge calcium-inname beschermend zou kunnen zijn voor het ontstaan van dikke darmkanker. De effecten van calcium-beperking op biologische kenmerken voor het risico op dikke darmkanker waren nog niet onderzocht.

In hoofdstuk 5 is een onderzoek beschreven met ratten die een stof kregen toegediend om calcium en magnesium uit de voeding niet beschikbaar te maken voor absorptie in de dunne darm: ethyleen diamine tetra azijnzuur of te wel EDTA. In hoofdstuk 6 is beschreven wat er gebeurde als wrijwillige mannen een medicijn innamen, dat door een bepaalde groep niersteenpatiënten wordt gebruikt om te voorkomen dat er te veel calcium uit de voeding wordt opgenomen in de dunne darm: Calcisorb ${ }^{(\circledR)}$. In beide gevallen werd verwacht, dat de concentraties van galzuren en vetzuren in het waterige deel van de darminhoud, respectievelijk ontlasting, zouden stijgen. Er werden echter geen verschuivingen gevonden in de concentraties. Dit is mogelijk veroorzaakt door de verlaging van de beschikbaarbaarheid van calcium tot beneden de $1000 \mathrm{mg} / \mathrm{dag}$. Uit de literatuur zijn aanwijzingen verkregen, dat calcium-supplementatie tot ruim boven de $1000 \mathrm{mg} / \mathrm{dag}$ de hoeveelheid ontlasting per dag verhoogt. Deze hogere hoeveelheid faeces per dag verlaagt waarschijnlijk de hoeveelheid galzuren in het waterige deel van de ontlasting, zoals af te leiden is uit ons onderzoek met de habituele omnivoren en vegetariers.

De concentraties van calcium en magnesium in het waterige deel van de darminhoud, respectievelijk ontlasting, waren lager na de interventie. De 
mogelijke rol van deze lagere concentraties voor het ontstaan van dikke darmkanker moet nog mader onderzocht worden in dierexperimentele en epidemiologische onderzoekingen, omdat beide mineralen ook een direct verlagend effect hebben op celdeling.

Het laatste onderzoek dat beschreven is in hoofdstuk 7, betrof de nadelige gevolgen van het calcium-beperkte dieet van een groep niersteenpatiënten (hypercalciurie type II) voor de kenmerken van de ontlasting die samenhangen met het risico op dikke darmkanker. Dit dieet wordt voorgeschreven,omdat deze patiënten re veel calcium absorberen in de dunne darm en daardoor te veel calcium uitscheiden in de urine. Ook hier werd een stijging van de concentraties van gal- en vetzuren in het waterige deel van de ontlasting verwacht. Echter deze concentraties daalden evenals de toxiciteit van het waterige deel van de ondlasting in een test met rode bloedcellen. Deze effecren werden hoogst waarschijnlijk veroorzaakt door de lagere inname van (verzadigd) vet en cholesterol die gepaard ging met de calcium-beperking door het weglaten van melkprodukten. De toxiciteit voot rode bloedcellen hing het sterkst samen met de concentratie van verzuren in het waterige deel van de ontlasting. De toxiciteit van het waterige deel van de ontlasting voor rode bloedcellen is gebleken goed overeen te komen met de toxiciteit voor epitheelcellen van de dikke darm en met de mate van celdeling in de dikke darm bij ratten. Vetzuren zouden het risico op dikke darmkanker kunnen verhogen, omdat ze evenals galzuren het enzym protein kinase $C$ activeren. Dit enzym speelt een cruciale rol bij het delen van cellen. Het verband tussen de concentratie van vetzuren in het waterige deel van de ontlasting en het risico op dikke darmkanker moet nog onderzocht worden in dierexperimentele en epidemiologische onderzoekingen. De $\mathrm{pH}$ van het faecale water daalde niet, maar aan het begin van het onderzoek gingen hoge waarden gepaard met grote hoeveelheid calcium in de ontlasting. Ook bleken hoge $\mathrm{pH}$ waarden samen te gaan met lage waarden van de toxiciteit woor rode bloedcellen. Hoge waarden van de hoevelheid ontlasting hingen samen met een hoge inname van calcium, gemeten door het optellen van de dagelijkse uitscheiding van calcium met de urine en de ontlasting, vooral boven $1000 \mathrm{mg}$ calcium per dag. Bovendien kon $65 \%$ van de variatie in de verandering van de hoeveelheid ontlasting per dag door het calcium-beperkte dieet verklaard worden door de verandering in calcium-inname.

In het onderzoek uit hoofdstuk 7 werden ook de effecten van het dieet op risicofactoren voor de vorming van calciumoxalaat-nierstenen gecheckt. De uitscheiding van calcium in de urine daalde iets en alleen bij mannen. De witscheiding van oxalaat daalde, hoewel niet statistisch significant. De citraatuitscheiding veranderde niet. 
Op grond van de afwezigheid van het verwachte effect van het calcium-beperkte dieet op de risicofactoren voor de vorming van calcium-oxalaat nierstenen en recente gegevens uit andere onderzoekingen, wordt in hoofdstuk 8 een nieuw schema voorgesteld woor de diagnose en therapie van niersteenpatiënten met calciumoxalaat-stenen, dat nog getest moet worden op efficientie en uitvoerbaarheid. Patiènten met een eerste niersteen worden onderzocht met medische, klinisch-chemische en antropometrische methoden. Als er geen metabole afwijkingen worden gevonden, wordt een gezonde voeding volgens de Nederlandse richthijnen woorgeschreven, bestaande uit normalisering van de hoeveelheid dierlijk eiwit, eieren, suiker en keukenzout, voldoende calcium en vocht en rijk aan groente en fruit. Van patiënten met terugkerende calciumoxalaat-stenen wordt 24 uurs urine geanalyseerd voor en na een streng gecontroleerd dieet volgens de Nederlandse voedingsrichtlijnen en een vaste hoeveelheid calcium in tabletworm. Patiènten bij wie de risicofactoren in de urine zoals calcium, oxalaat, uraat, citraat, magnesium dalen en stoffen in de urine die indicatoren zijn voor de het voorgeschreven dieet zoals ureum en natrium, ook dalen, krijgen een gezonde voeding aanbevolen. Patiënten bij wie de calcium-uitscheiding in de urine niet daalt op het dieet met calcium, maar wel op het dieer zonder de calcium-tabletten, worden gediagnosticeerd als patiënten met hypercalciurie type II. Alleen deze groep krijgt een calciumen oxalaatbeperkt en vochtrijk dieet. Verder onderzoek is nog nodig om na te gaan welke van deze patiënten een verhoogd risico op botontkalking hebben tengevolge wan dit dieet.

Tenslotre wordt in hoofdstuk 8 een aangepast model gepresenteerd voor de rol van ontlastingskenmerken bij het ontstaan van dikke darmkanker en de invloed van voedingsbestanddelen op deze kenmerken. Bestanddelen van de ontlasting zoals vetzuren en hydrofobe galzuren in het waterige deel van de ondlasting kunnen de deling van epitheelcellen wan de dikke darm verhogen. Hierdoor komen veranderingen in her DNA van deze cellen eerder tot uiting. Er zijn sterke aanwijzingen dat een voeding bestaande uit alleen plantaardige produkten (veganistisch) beschermend zal zijn tegen het ontstaan van dikke darmkanker door zijn laag gehalte aan verzadigd vet en cholesterol en zijn hoog gehalte aan voedingsvezel en langzaam verteerbaar zetmeel. Hierdoor zullen de concentraties van hydrofobe galzuren en van wetzuren in het waterige deel van de ontlasting laag zijn. Bovendien zal de grote hoeveelheid voedingsvezel en langzaam verteerbaar zetmeel de productie van boterzuur in de dikke darm verhogen, waardoor de deling wan de epitheelcellen van de dikke darm geremd wordt. Lacto-ovo-vegetarische voeding die niet zo'n lage hoeveelheid verzadigd vet bevat als een veganistische voeding, zal beschermen tegen dikke darmkanker omdat ze een grote hoeveelheid voedingsvezel, langzaam verteerbaar zetmeel en calcium bevat. De voedingsvezel en het calcium 
zullen de hoeveelheid ontlasting per dag verhogen en daardoor de concentraties van hydrofobe galzuren en verzuren in het waterige deel van de ontlasting verlagen. Bovendien zal her calcium de zuurgraad van de ontlasting verhogen, waardoor de hoeveetheid ongedissocieerde secundaire galzuren zal afnemen. Juist deze ongedissocieerde galzuren zijn hydrofoob en daardoor toxisch voor cellen. Omnivore voeding die meestal weinig voedingsvezel, soms weinig calcium en vaak veel (verzadigd) vet en cholesterol uit wlees en eieren bevat, zal het risico op dikke darmkanker verhogen.

Het risico op niersteenvorming bij mannen die erfelijk belast zijn met een werhoogd risico op calciumoxalaat-stenen, kan mogelijk iets verlatagd worden. Het risico op dikke darmkanker zal niet stijgen als de melkprodukten niet vervangen worden door voedingsmiddelen rijk in dierlijk eiwir, zoals vlees en eieren, of door andere voedingsmiddelen. Echter voor vrouwen is dit diet waarschijnllijk niet effectief en verhoogt het mogelijk hun risico op botontkalking. Een voeding zoals beschreven in de Nederlandse richtlijnen voor gezonde voeding, zal voldoen aan de aanbevelingen voor verlaging van het risico op herhaalde vorming van calciumoxalaat-nierstenen en tegelijk aan die voor de vermindering van het risico op botontkalking en dikke darmkanker. 



\section{Dankwoord}

Velen hebben bijgedragen aan het tot stand komen wan dit proefschrift door hun medewerking, adviezen en/of interesse. Ik denk hierbij vooral aan mijn ex-en huidige collega's uit Nijmegen, Zeist en Maastricht, familieleden en vriender. De onderstaande personen wil ik met naam noemen.

Prof. Janknegt, u gaf mij het vertrouwen het onderzoek rond de niersteenpatienten te leiden van subsidieaanvraag tot eindrapportage.

Ruud Hermus, jouw begeleiding op her gebied van roedingsonderzoek en je kritische houding ten opzichte van mijn onderzoeksactiviteiten hebben mij veel geleerd.

Roelof van de Meer, jouw kennis van en ideeën over de chemie en fysiologie van galzuren en darminhoud waren heel stimulerend voor mij.

Ton van den Bogaard, jouw enthousiasme en inzet voor gal- en vetzuren in relatic tot her ontstaan van dikke darmkanker en jouw kennis van de faculteit Geneeskunde van de Rijksuniversiteit Limburg hebben het mogelijk gemaakt mijn onderzocksaktiviteiten in Nijmegen en Zeist met succes voort te zerten in Maastricht.

Sandra Bausch-Goldbohm, Piet van den Brandt en Pieter van 't Veer, jullie kameraadschap vanaf onze TNO-tijd en jullie deskundigheid op het gebied van de epidemiologie zal ik nooit vergeten.

Wim van Dokkum, jij leerde me hoe je moer omgaan met proefpersonen.

Fokko Nagengast en Toon Huijbregts, onze gezamenlijke publikatie was het resultaat van een heel prettige samenwerking.

Paul Borm, jouw interesse in molekulaire epidemiologie heef me naar Limburg doen verhuizen en daar verder doen gaan met mijn ingeslagen onderzoeksrichting.

Jan Glatz, jouw eryaring met het meten van galzuren in ontlasting konden we goed gebruiken in Maastricht. Ook een deel van je onderzocksresultaten mocht ik gebruiken woor dit proefschrift.

Chanin Boekhoudt, samen mer jou heb ik eraan gewerkt zoveel mogelijk patienten in het onderzoek te krijgen. Dit lukce dankzij de medewerking van 
de (assistent)-urologen in her Academisch Ziekenhuis Maastricht en de wolgende urologen in de andere deelnemende ziekenhuizen: V.W.J. de Kort, P.J.N. Kil, L.M.H. Schreinemachers, J.C. Schepers en J.J.M. Kums. Ook dr. H.K. Kreutzer, klinisch-chemicus, wist nog een aantal patienten. San de Kort, zonder jouw gecomputeriseerde beslisboom woor her diagnosticeren van niersteenpatiënten was het onderzoek niet mogelijk geweest.

Carolien Jacobs en Lisette wan den Tweel, jullie waren bereid naast onze PBI-klanten ook mijn urologische klanten te woord te staan.

Phil Geerlings, jij zorgde in mijn urologische periode voor de continuiteit in het berekenen van de voedingsgegevens.

Judith Beeser, als collega vanaf 'Arbeidsgeneeskunde' was jij bereid mijn Engelse schrijfstijl te verbeteren.

Geertjan van Zonneveld, bedankt voor je meedenken bij en het uitvoeren van de illustraties voor dit proefschrift.

Mijn paranimfen, Liesbeth van der Ploeg en Math Hazen hebben mij ook tijdens de opzet, uirvoering en rapportage van het onderzoek in Maastricht ter zijde gestaan.

Last but not least dank ik mijn partner, Bert Hoogveld, voor zijn interesse in en waardering voor mijn werk. 


\section{Curriculum Vitae}

Arendina (Diny) van Faassen werd geboren op 7 maart 1953 te Slagharen. In 1970 haalde zij het h.b.s.-B diplona aan het christelijk arheneum "Jan van Arkel" re Hardenberg. In 1973 verkreeg zij her kandidaatsdiploma scheikunde met wiskunde en natuurkunde $\left(S_{1}\right)$ aan de Rijlsuniversiteit Groningen. Het doctoraalexamen scheikunde deed zij in 1978 en bestond uit her hoofdvak Biochemie en het bijvak Humane Voeding. Gedurende cen jaar werrichte ze molekulair-biologisch onderzoek in het Laboratorium voor Fysiologische Chemie van de Rijksuniversiteit Groningen.

Van 1980 tot 1983 was ze fellow van de Nederlandse Kankerbestrijding - het Koningin Wilhelmina Fonds. Ze werkte achtereenvolgens op de afdeling Gastro-enterologie wan thet Academisch ziekenhuis Sint Radboud in Nijmegen en de afdelingen Voeding en Toxicologie van TNO-Voeding in Zeist. Ze volgde cursussen epidemiologie en statistiek aan de Rijksuniversiteir Leiden en Landbouwuniversiteit Wageningen.

Bij TNO-Voeding verrichtte ze van 1984 tot half 1986 epidemiologisch onderzoek naar de relatie tussen voeding en het ontstaan van kanker. Daarna deed ze gedurende twee jaar arbeids- en milieuhygiënisch onderzoek bij de vakgroep Arbeidsgeneeskunde, Milieugezondheidkunde en Toxicologie van de Rijksuniversiteit Limburg. Na een half jaar gewerkt te hebben als zelfstandig adviseur op het gebied van kwaliteitszorg, trad ze in 1989 in dienst bij het Projektbureau voor Industrie en Milieu (P.B.I. b.v.) te Maastricht als adviseur Kwaliteirs-, Arbo-en Milicuzorg.

Vanaf 1990 werkt ze 1 dag per week bij de afdeling Urologie van het Academisch ziekenhuis Maastricht. Tevens is ze momentel 3,5 dag per week werkzam als arbeidshygiënist en biologisch veiligheidsfunctionaris bij de Rijksuniversiteir Limburg en het Academisch Zickentuis Maastricht. In 1993 werd ze erkend als epidemioloog A en in 1994 werd ze geregistreerd als arbeidshygiënist. 



\section{List of Publications}

\section{First author}

wan Faassen, A. and Huijluregts, A. W. M. "Leter to the editor" J. Lipid Res. 23 (1982) 508

wan Fassen, A. en Pieters, J.J.L. Voeding en magkkanker. I. Onstansmechanisme an persoonsgebonden facroren. Voeding 44 (1983) 378-383; II. Omgewings-en voedingsfictoren. Voeding 44 (1983) 412-420 (in Dutch)

van Faassen, A., Egger, R.J. and Hermus, R.J.J De kewxe wan een biochemische paramerer voor de seleenvoorziening van de mens. T. Soc. Gezondheidsz. 61 (1983) 831-833 (in Dutch)

wan Faassen, A. Voeding en coloncarcinoom in Griekenland. Voeding 45 (1984) 231-232 (m Dutch)

van Faassen, A., Nagengast, F.M., Hectors, M., van den Broek, W.I.M., Huijbregts, A.W.M., van der Werf, S.D.J., van Berge Henegouwen, G.P. and van Tongeren. J.H.M. Deremination of indiwidual faecal bile acids by gas-liquid chromatography using dimethoxypropane for simultaneous solvolysis and methylation. Clin. Chim. Actat 152 (1985) $231-239$

Wan Faassen, A., Bol, J, wan Dokktum, W. Pikaar, N.A., Ockhuizen, Th. and Hermus, R.J.J. The infuence of a mixed, a lacto-ovo-vegetarian and a vegan diet on bile acids, neural sterouds and bacteria in feces. A.m. J. Clin. Nutr. 46 (1987) 962-967

wan Faassen, A. Cardinats, J.M., wan 't Veer, P., Ockhuizen, Th., Muys, T. and Wointicz, J.R.W. Selenium status parameters: response to a six-week dietary modification and intra-and. in-terindividual variabilicy. In: Trace Element Analytical Chemistry in Medicine and Biology, Vol. 4. P. Bratter and P. Schramel (eds.), Berlin, De Grutyter, 1987, p. 289-299

wan Faassen, A. Hoe bewatke her lab de kwalicet. Laboratonium Praktijk november 1990 , $382-383$ (in. Dutch)

yan Faassen, A. Reakries: Voeding en kanker. Chemisch Weekblad 25 novenber 1990 (in Dutch)

wan Faassen, A. Engelen. J., Falke, H.E. and Hermus, R.J.J. Glutathione peroxidase activity as a bionvarker of the selenium staks of man. In: Biomarkers of dictary exposure. Proc. 3rd meering on nutricional epidemiology. Kok, F.) and wan "t Veer, P. (cots), London, Smith-Gor" don and Company Limited, 1991, p. 113.114

Van Faassen, A.. and Borm, J.A. Composition and heath hazards of waterborne construction paints: results from a survey in the Netherlands. Env. Healdh Persp. 92 (1991) $147-154$ 
wan Fassen, A. van "t Veer, P. Bausch-Goldbohm, R.A., Stur-mans, F. and Hermus, R.J.J. Self-assesmenc of faecal $\mathrm{pH}$ and bulk in epidemiological studies. Br. J. Cancer 65 (1992) 735.736

van Faasen, A, Hazen, M.J., van den Bogaard, A.E., van der Ploeg, L., Janknegt, R.A. Faecal deoxycholzuur als "biomarker" woor een dikke darm kanker bevorderende voeding. Voeding 53 (1992) 96 (in Dutch)

van Faassen, A., Hawen, M.J, wan der Brandt, P.A., van den Bogaard, A.E., Hermus, R.J.J. and Janknegt, R.A. Bile acids and pH in total and the aqueous phase of faeces from habitual omnivores and vegetarians. Am. J. Clin. Nutr. 58 (1993) $917-922$

van Faassen, A. van den Bogaard, A.E., Hazen, M.J., Janknegt, R.A. Effecrs of a calcium binder on the solubility of bile acids and fatry acids in the large intestine of the rat. Cancer Lete. $81(1994) 77-80$

van Faassen, A. Certificering van arbozorg in laboratoria als onderdeel van her kwaliteits" zorgsystem. Acadcmisch Ziekenhuis Masstricht, Maastricht, 1995. 1SBN nr 90-73265-06-1 (in Durch)

\section{Co-author}

van Dokkum, W., de Boer, B.C.J, van Faassen, A. Pikaar, N.A. and Hermus, R.J.J. Dier, faecal pH and colorectal cancer. Br. J. Cancer 48 (1983) 109-110

Berkel, J, wan Faassen, A., van Leeuwen, F. E en Sinkeldam, E. J. Voeding en coloncarcinoom. I. Epidemiologie. Voeding 45 (1984) 150-158; II. Dierexperimenteel onderzoek en ontstaansmechanismen. Voeding 45 (1984) 246-255 (in Dutch)

Bol, J., Minekus, M. Sinkeldam, E.J. and van Faassen, A. Influence of Temoe Lawak (curcuma product) on Lactobacillus acidophilus and Clostridium paraputrificum and bowel micro-organisms of rats in eenerall. T. Fond Sci. Techn. $22(198517-10$

Wan "t Veer, P., van Faassen, A., Egger, R.J. Ockhuizen, Th. and Hermus, R.I.J. Dietary selenium, selleniumstatus, fat consumption and body composition; a case-control sudy on the etiology of pre- and postmenopausal breast cancer. In: Diet and human carcinogenesis. J.V. Joossens, M.J. Hill, J. Geboers (eds), Amsterdam, Elsevier Science Publishers, 1985, p. $207-212$

van 't Veer, Egger, R.J, wan Faassen, A., Ockhuizen, Th., Sturmans, F., Hermus, R.J.j. Selenium en ver in de voeding in relatie tot borstkanker. T.Soc.Gezondheidsz. 63 (1985) 886 (in Dutch)

wan 't Veer P. van Faassen, A., Egger, R. J., Bausch-Goldbohm, R.A., van den Brandt, P.A., Ocklhuizen, T., Hermus, R.J.J. and Stumans, F. Relation between selenium in biological samples and dierary intake from different food groups. Cancer Lett. $30(1986) 5105$ 
van 't Veer, P., van Faassen, A., Hermus, R.J.]. en Ockhuizen, Th. De betekenis van selenum in de woeding. Ned. Tijdsch. Geneeskd. 131 (1987) 1036-1039 (in Duteh)

de Kok, T.M.C.M., wan Faassen, A., Bausch-Goldbolum, R.A., ten Hoor, F. and Kleinjans, J.C.S. Fecapentaene excretion and fecal mutagenicity in relarion to nutrient intake and fecal parameters in humans on omnivorous and vegetarian diets. Cancer Letters 62 (1992) 11-21

Kok, T.M.C.M., Levels, P.J., van Fassen, A., Hazen, M., ten Hoor, F. and Kleinjans, I.C.S. Chromarographic methods for the derermination of toxicants in faeces. J. Chromatogr. 580 (1.992) $135-159$ 